\title{
A Review of the Biology of Cerataphidini (Hemiptera, Aphididae, Hormaphidinae), Focusing Mainly on Their Life Cycles, Gall Formation, and Soldiers
}

\author{
Shigeyuki Aoki ${ }^{1}$ and Utako Kurosu ${ }^{2}$ \\ ${ }^{1}$ Faculty of Economics, Rissho University, Osaki 4-2-16, Tokyo 141-8602, Japan \\ ${ }^{2}$ Faculty of Economics, Chuo University, 742-1 Higashinakano, Hachioji, Tokyo 192-0393, Japan \\ Correspondence should be addressed to Shigeyuki Aoki, oregma@rb3.so-net.ne.jp
}

Received 22 September 2010; Accepted 8 December 2010

Academic Editor: Ai-Ping Liang

Copyright ( $) 2010$ S. Aoki and U. Kurosu. This is an open access article distributed under the Creative Commons Attribution License, which permits unrestricted use, distribution, and reproduction in any medium, provided the original work is properly cited.

\begin{abstract}
Species of the aphid tribe Cerataphidini (Hormaphidinae) form galls of various shapes on Styrax trees, their primary host, throughout East and Southeast Asia including tropical rainforests. All known species of the tribe produce second-instar sterile soldiers on the primary host and some also produce first-instar sterile soldiers on the secondary host. Here, we review their complicated life cycles with or without host alternation, the formation process of their remarkable galls (flower-like multiplecavity galls in particular), and all morphs including soldiers. The life cycles of cerataphidines are basically the same as those of the subfamily Eriosomatinae, but in tropical and subtropical regions their life cycles are not very rigidly tuned to seasonal changes in the climate if any. In addition, cerataphidine galls in these regions last at least several months, or at times even for over one year; thus it often takes longer than one year to complete their life cycles.
\end{abstract}

\section{Introduction}

The tribe Cerataphidini is an aphid group of approximately 90 species [1], whose members produce sterile soldiers [2,3]. So far as is known, all species produce sterile second-instar soldiers in their galls on the primary host, and some species also produce sterile first-instar soldiers in their open colonies on the secondary host [4-7]. They induce remarkable galls on trees of the genus Styrax (Styracaceae), which become huge (up to $35 \mathrm{~cm}$ across) in some species [8-11]. For these reasons, the group has recently attracted much attention from researchers both inside and outside aphidology [1214]. However, although some good reviews of aphid soldiers in general have been published $[6,7,15]$, no extensive review of the life cycles of Cerataphidini (nor of their gall formation) has been available to date. Because their life cycles and the process of gall formation are complicated, it can be difficult for non-aphidologists (and even aphidologists, too) to gain a thorough understanding of their biology. In this review, we first focus on the life cycles and illustrate their various kinds in temperate, subtropical, and tropical regions. Second, we focus on how their galls, their flower-like multiple-cavity galls in particular, are formed by the aphids and explain the hypothesis that the aphids may exploit the mechanism of flower formation in the host plant for their gall formation. Third, we present a review of aphid morphs that appear in the life cycles. In this section, behavioral aspects of soldiers are reviewed and discussed.

\section{General Features of the Tribe Cerataphidini}

2.1. Taxonomic Position. The tribe Cerataphidini belongs to the gall-forming subfamily Hormaphidinae. The Hormaphidinae is a sister group of another gall-forming subfamily, the Eriosomatinae (formerly called "Pemphiginae") [50] (but see also [51]), whose life cycles have been studied better [52-54] because many species are distributed in Europe and North America. The Hormaphidinae consists of three tribes, Cerataphidini, Hormaphidini, and Nipponaphidini, 
TABle 1: Primary hosts of Cerataphidini.

\begin{tabular}{|c|c|c|}
\hline Cerataphidine genus & Styrax species & Styrax series \\
\hline Astegopteryx & S. suberifolius [16], S. benzoides [17], S. benzoin $[18,19]$ & Benzoin \\
\hline Ceratovacuna & $\begin{array}{l}\text { S. japonicus }[20,21], \text { S. formosanus [22], S. obassia [23, 24], S. } \\
\text { tonkinensis }{ }^{1} \text {, S. serrulatus }{ }^{2} \text {, S. paralleloneurus }[25]\end{array}$ & Cyrta, Benzoin \\
\hline Pseudoregma & S. suberifolius [26, 27], S. benzoides [28], S. paralleloneurus [29] & Benzoin \\
\hline Ceratoglyphina & $\begin{array}{l}\text { S. suberifolius [30], S. ?benzoin [31], S. fraserensis [32], S. } \\
\text { paralleloneurus [31] }\end{array}$ & Benzoin \\
\hline Chaitoregma & Unknown & \\
\hline Cerataphis (with Buchnera) & S. suberifolius [33], S. subpaniculatus [10] & Benzoin, Cyrta \\
\hline Cerataphis (without Buchnera) & S. benzoides ${ }^{3}$, S. benzoin [34], S. suberifolius [35] & Benzoin \\
\hline Tuberaphis & $\begin{array}{l}\text { S. japonicus [36], S. formosanus [37, 38], S. obassia [39], S. tonkinensis } \\
\text { [11], S. subpaniculatus }[40,41]\end{array}$ & Cyrta \\
\hline Glyphinaphis & Unknown & \\
\hline
\end{tabular}

TABLE 2: Secondary hosts of Cerataphidini.

\begin{tabular}{ll}
\hline Cerataphidine genus & Plants \\
\hline \multirow{2}{*}{ Astegopteryx } & Gramineae (Bambusoidea, grass) [42], \\
& Zingiberaceae [42], Palmae [42], \\
Ceratovacuna & Pandanaceae [42], Musaceae [43, 44] \\
& Gramineae (Bambusoidea, grass) [42] \\
Pseudoregma & Gramineae (Bambusoidea, grass) [42], \\
& Zingiberaceae [42] \\
Ceratoglyphina & Gramineae (Bambusoidea) [42] \\
Chaitoregma & Gramineae (Bambusoidea) [45] \\
& Gramineae (Bambusoidea) [46], Palmae \\
& {$[42]$, Pandanaceae [42], Orchidaceae } \\
Cerataphis & [42], Araceae [42], Strelitziaceae [47], \\
& Smilacaceae [48], Moraceae [43], \\
Tuberaphis & Zingiberaceae ${ }^{1}$ \\
Glyphinaphis & Loranthaceae [42], Santalaceae [49] \\
& Gramineae (Bambusoidea) [42]
\end{tabular}

${ }^{1}$ We examined specimens (apterous adults and nymphs) of Cerataphis sp. collected from a plant of Zingiberaceae by T. Fukatsu at Genting Highland, West Malaysia, on 17 November 1995.

in addition to a few genera (Aleurodaphis, Doraphis, Protohormaphis, and Tsugaphis) whose taxonomic positions are unclear within the subfamily and which have been tentatively assigned to some of the three tribes. The members within each tribe are well unified in the sense that the primary hosts of Hormaphidini, Nipponaphidini, and Cerataphidini are confined to a single plant genus, Hamamelis (Hamamelidaceae), Distylium (Hamamelidaceae), and Styrax (Styracaceae), respectively. (Galls of some nipponaphidines have recently been found on trees of the genera Distyliopsis and Sycopsis (Hamamelidaceae) in Taiwan [55].)

2.2. Genera within the Cerataphidini. The Cerataphidini consists of the following eight genera, Astegopteryx, Ceratovacuna, Pseudoregma, Ceratoglyphina, Chaitoregma, Cerataphis,
Tuberaphis, and Glyphinaphis. The genus Aleurodaphis was once placed in this tribe $[36,42]$, but molecular data did not support this placement $[6,56]$. In addition, one species of Aleurodaphis was found to induce galls on Stewartia monadelpha (Theaceae) [57], not on Styrax. The monotypic genus Doraphis has also been placed in the Cerataphidini $[1,54]$, perhaps because the second generation on Populus has a pair of frontal horns. However, its life cycle [52] is similar to those of Hamamelistes species (Hormaphidini) $[58,59]$ in that coccidiform first-instar nymphs hibernate on twigs of the host tree, and the genus is unlikely to belong to the Cerataphidini.

Within the Cerataphidini, the first four genera (Astegopteryx, Ceratovacuna, Pseudoregma, and Ceratoglyphina) are known to induce peculiar, multiple-cavity galls and, together with Chaitoregma whose galls are unknown, constitute a monophyletic clade $[20,60]$. This has been confirmed by molecular phylogenetic analyses $[18,31,56,61]$. The genera Cerataphis and Tuberaphis form single-cavity galls as many other gall aphids do. Galls of Glyphinaphis are yet unknown. So far as is known, all species of Tuberaphis and Glyphinaphis and most (but not all) species of Cerataphis harbor extracellular, eukaryotic symbionts instead of the prokaryote Buchnera [60]. If the acquisition of the extracellular symbionts happened only once in the lineage, the species group with the extracellular symbionts (Tuberaphis, Glyphinaphis, and some Cerataphis) constitutes a monophyletic clade, but the genus Cerataphis, which includes species with extracellular symbionts (e.g., C. brasiliensis, $C$. jamuritsu) and those without them (C. vandermeermohri, $C$. bambusifoliae), is not [33]. Molecular phylogenetic analyses have not yet definitely settled the issue $[18,31,56,61$, $62]$.

2.3. Geographic Distribution. Cerataphidines are mainly distributed in East and Southeast Asia. They induce galls on trees of the genus Styrax, their primary host. All known 
primary-host generations have been found there. The northernmost record is of Tuberaphis styraci on Styrax obassia in Sapporo $\left(43^{\circ} \mathrm{N}\right)$, Hokkaido, northern Japan [63]. The southernmost record is in Java $[42,64]$. The westernmost record is in eastern India or Nepal (see footnote 2 of Table 1), and the eastern border is approximately the line from Japan through Sulawesi [65] to Java. Trees of the genus Styrax are also distributed in the New World, and the species occurring in eastern North America (e.g., S. americanus, S. grandifolius) belong to the series Cyrta (Section 2.4). The series includes Asian Styrax japonicus and S. obassia [66, 67], which are used as the primary hosts of several cerataphidines. Fritsch [66] suggests that a single vicariance event between eastern Asia and eastern North America accounts for the intercontinental disjuncts in the series Cyrta. The absence of cerataphidine galls in the New World therefore suggests that cerataphidines went into temperate regions of Asia in a relatively recent era, after the series Cyrta was divided into the two continental groups.

Like many other aphids, most cerataphidines can live on the secondary host throughout the year. Some cerataphidines are thereby distributed beyond the range of the primary host. Cerataphis brasiliensis (on palms) and Pseudoregma panicola (on grass) have a pan-tropical distribution [68] and probably have recently invaded the New World, Africa and Australia. Cerataphis brasiliensis, C. lataniae (on palms), and C. orchidearum (on orchids) often occur in the greenhouse in temperate regions [69-71].

2.4. Primary Hosts. The primary hosts of cerataphidines are trees of the genus Styrax. According to Fritsch [66], the genus is divided into two sections, Styrax and Valvatae. Species of the section Styrax are temperate (or tropical) deciduous trees, while those of Valvatae are tropical evergreen. The section Styrax is further divided into two series, Styrax and Cyrta. Both have disjunct distributions between the Old and New worlds. Species of the series Styrax are known from western North America and western Eurasia, and those of the series Cyrta from eastern Asia and eastern North America. The section Valvatae is also divided into two series, Valvatae and Benzoin. The former is a neotropical clade, while the latter is a paleotropical clade, occurring in Southeast Asia. Cerataphidines are associated with the series Cyrta and Benzoin. So far, the aphid genera Pseudoregma, Astegopteryx, and Ceratoglyphina have been known from Benzoin, Tuberaphis from Cyrta, and Cerataphis and Ceratovacuna from both series (Table 1). Some cerataphidine species form galls on more than one Styrax species within a single series (e.g., Ceratovacuna nekoashi on Styrax japonicus [21], S. formosanus [22], and S. obassia [23, 24]), but no cerataphidine species has been known from Styrax species across series.

2.5. Secondary Hosts. The secondary hosts of the Cerataphidini are wider in range than their primary hosts and include several unrelated plant families (Table 2). All the genera but Tuberaphis contain at least one species that uses Bambusoidea (Bambusa, Dendrocalamus, Gigantochloa, Pleioblastus,
Sasa, etc.) as the secondary host. Palmae (palms) and/or Zingiberaceae (gingers) are also often used by tropical species of the genera Pseudoregma, Astegopteryx, and Cerataphis. The genus Tuberaphis is peculiar in that its secondary hosts are confined to mistletoes of the families Santalaceae (Viscum) [49] and Loranthaceae (Loranthus, Scurrula, Dendrophthoë, and Macrosolen) [42].

\section{Life Cycles}

Life cycles of the Cerataphidini can be classified into (1) host-alternating (heteroecious), (2) non-host-alternating (monoecious) life cycles (on the primary host), and (3) anholocycly (on the secondary host) (Figure 1). Host alternation can further be classified into (Figure 1(a)) obligate hostalternation and (Figure 1(b)) facultative host alternation. In obligate host alternation, aphids on the secondary host perish after alates (sexuparae) have flown back to the primary host. In facultative host alternation, some aphids survive on the secondary host after sexuparae fly away. From facultative host-alternating life cycles, anholocycly on the secondary host can be easily derived. In an anholocyclic species or population, aphids can persist on the secondary host over many years without sex; alate sexuparae may or may not be produced, but they are functionless and do not pass their genes to subsequent generations. Non-host-alternating life cycles on the primary host are known to occur sporadically within the Cerataphidini: one species in Astegopteryx [17], one in Ceratoglyphina [72], and three in Tuberaphis [11, $39,40]$. In some species with host-alternating or nonhost-alternating life cycles, it takes longer than one year to complete their life cycles; their galls grow slowly and do not produce any alates within the first year $([30,33,73]$, see also [74]). In the following, we describe examples of such life cycles in temperate, subtropical, and tropical Asia.

3.1. Obligate Host Alternation in Temperate Asia. The life cycle of a temperate species, Ceratovacuna nekoashi, is easy to understand if readers have some knowledge about the life cycles of Eriosomatinae such as Pemphigus bursarius [75, 76] or Tetraneura ulmi [77]. In Tokyo and its vicinity, fundatrices of $C$. nekoashi hatch in spring and transform a lateral bud of a developing shoot of the deciduous snowbell Styrax japonicus into a characteristic "cat's-paw" gall [21] (Figure 2(a)). How such a gall is formed is explained in Section 4.2.4. The fundatrix is followed by one or two generations of apterous adults in the gall. Some of the offspring of these apterous adults grow into second-instar sterile soldiers that play a defensive role. From July onward, alates called "emigrants" develop in the gall, and they fly to the grass Microstegium vimineum, their secondary host, and give birth to first-instar offspring on the undersides of its leaves. The nymphs and adults of the secondary-host generation (called "exules"; see Section 5.4) (Figure 2(b)) are characterized by a pair of frontal horns. In October, alates called "sexuparae" (Section 5.5) appear on M. vimineum and fly back to $S$. japonicus. They deposit tiny sexuals (males and oviparous females) on the undersides of snowbell leaves. 


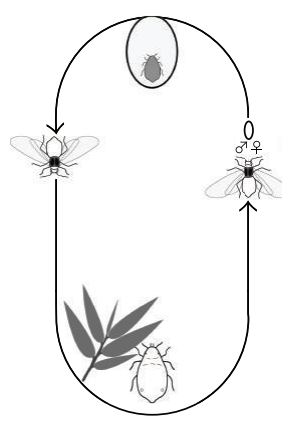

(a)

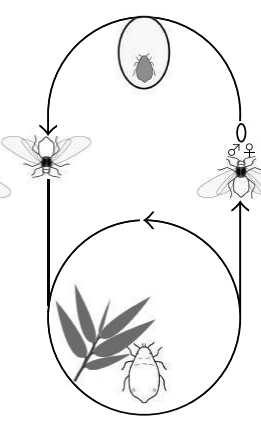

(b)

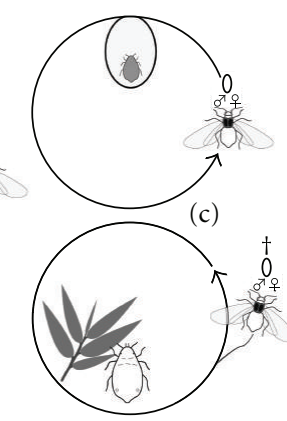

(d)

FIGURE 1: Life cycles of cerataphidines. Gall generation (upper) and secondary-host generation (lower), together with alates (emigrant and sexupara), are schematically shown. (a,b) Host-alternating (heteroecious) life cycle: in obligate host alternation (a) aphids cannot persist without returning to the primary host, while in facultative host alternation (b) aphids can survive on the secondary host throughout the year. (c) Non-host-alternating (monoecious) life cycle on the primary host; alate sexuparae produced in the gall fly to the primary host. (d) Anholocycle on the secondary host; alate sexuparae (if any) are functionless.

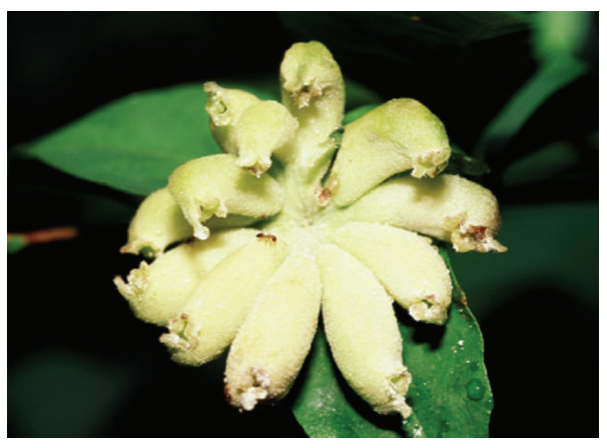

(a)

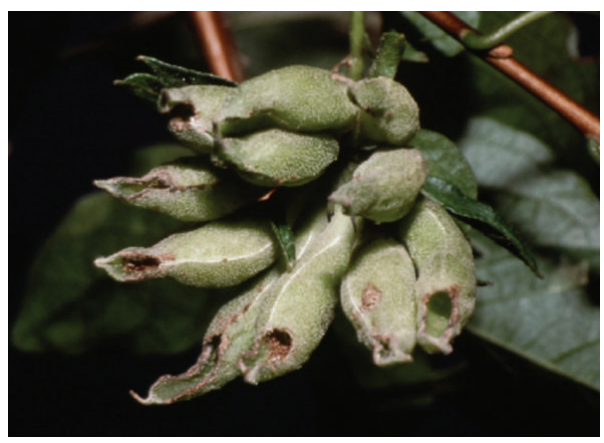

(c)

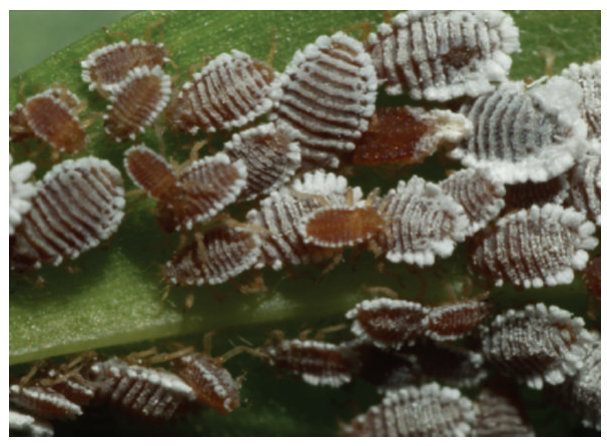

(b)

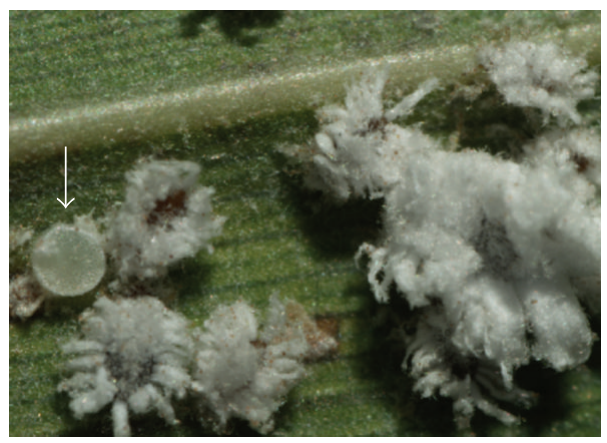

(d)

Figure 2: (a) A gall of Ceratovacuna nekoashi on Styrax japonicus (Seoul, South Korea; 3 August 1998). (b) A colony of C. nekoashi on the grass Microstegium vimineum (Niiza, Japan; 12 August 2009). (c) A gall of Ceratovacuna japonica on S. japonicus (Niiza; September 1990; photo by D. L. Stern). (d) A colony of C. japonica on the bambusoid Pleioblastus chino; an egg of the predaceous lycaenid Taraka hamada (indicated by an arrow) is laid in the colony (Kumagaya, Japan; 24 October 2009).

The sexuals move to branches and mature in the fissures of bark without feeding [78]. There, they copulate and females each lay a single egg that overwinters $[79,80]$.

Because Microstegium vimineum is an annual grass, no aphids persist on the secondary host during winter. In this sense, its host alternation is obligate (Figure 1(a)).

3.2. Facultative Host Alternation in Temperate Asia. The life cycle of another temperate species, Ceratovacuna japonica, is almost the same as that of $C$. nekoashi. Fundatrices induce similar banana-bunch-shaped galls (Figure 2(c)) on Styrax japonicus in a similar manner [20]. In central Japan, alates appear in the gall from July onward and fly to secondary hosts, small bambusoids such as Pleioblastus chino [81]. Alate sexuparae appear in October and fly back to $S$. japonicus.

Exules, or secondary-host generations, have also been recorded from Pleioblastus simonii (as "Arundinaria" simonii [82]) and Sasa senanensis [83]. These plants belong to 
the Bambusoidea and are perennials. Exules of Ceratovacuna japonica (Figure $2(\mathrm{~d})$ ) propagate themselves by parthenogenesis throughout the year on these perennial secondary hosts. In this sense, host alternation of this species is facultative (Figure 1(b)). In some populations, colonies on the secondary host produce few alate sexuparae in autumn, and galls of this species are much rarer than those of $C$. nekoashi in and around Tokyo [20] despite the fact that colonies on Pleioblastus chino are rather commonly found there [84]. The exules are cold-tolerant. They reproduce even during winter in the Kanto District, and a colony containing apterous adults was found on leaves of Sasa senanensis above snow cover by Hitoshi Hasegawa (personal communication) at Hida Osaka, Gifu Prefecture, in February (recorded as Ceratovacuna "sp. A" [85]).

In colonies on the secondary host, Ceratovacuna japonica produces sterile, first-instar "pseudoscorpion-like" soldiers $[83,84]$. The presence of soldiers may contribute to the persistence of colonies on the secondary host. The species does not produce alates that disperse between the secondary hosts (called "secondary migrants"; see Section 5.6). Instead of alates, first-instar nymphs disperse on the wind [84].

3.3. Anholocycly in Temperate Asia. Anholocycly is a life cycle without sexual reproduction. In Hormaphidinae, anholocycly occurs only on the secondary host. Ceratovacuna cerbera, which is known from southern Korea and central Japan, lives parthenogenetically throughout the year on Sasa spp. including S. borealis and S. veichii [86]. At the Shomaru Pass $\left(36^{\circ} \mathrm{N}\right)$, central Japan, alates appear in October/November. However, they are not sexuparae that would fly to the primary host but secondary migrants that fly to another plant of the secondary host. Because no sexuparae are produced, the life cycle is anholocyclic there. This does not exclude the possibility that sexual reproduction might occur elsewhere. Like C. japonica (Section 3.2), C. cerbera produces sterile first-instar soldiers [86].

3.4. Facultative Host Alternation in Subtropical Asia. In subtropical regions such as Taiwan, seasonal changes are still pronounced, but the climate has a mild winter, during which aphids can reproduce. The life cycles of cerataphidines show seasonality there. Here in after we describe three facultatively host-alternating species native to this region, Astegopteryx bambucifoliae, Pseudoregma bambucicola, and Ceratoglyphina styracicola, all of which form galls on the evergreen Styrax suberifolius and migrate to Bambusoidea.

3.4.1. Astegopteryx bambucifoliae. Secondary-host generations, or exules, of Astegopteryx bambucifoliae are yellowish aphids with green patches (Figure 3(b)) and known as pests of economically important bamboos such as Dendrocalamus latiflorus and Bambusa oldami [45]. Their colonies are formed on the undersides of bamboo leaves and individual aphids are more or less spaced out from each other [87]. Unlike the temperate species mentioned above, colonies of $A$. bambucifoliae produce many alate sexuparae in spring (from February to May) instead of autumn. They fly to leaves of
Styrax suberifolius and deposit sexuals on the undersides. These first-instar sexuals soon leave the leaves and hide in narrow spaces such as in unfolding buds of the host tree, in old dead galls of cerataphidines, or even in unfolding buds of a non-host vine coiling the host tree [16]. They mature and copulate, and females each lay a single egg. Firstinstar fundatrices soon hatch from the eggs and induce galls (Figure 3(a)) on stems of developing shoots of S. suberifolius. Kurosu and Aoki [16] guessed that gall formation takes place in June in Puli $\left(23^{\circ} \mathrm{N}\right)$, central Taiwan. However, incipient galls are seen from May to July or sometimes even in September in Taipei $\left(25^{\circ} \mathrm{N}\right)$ [88]; thus the gallforming period is longer in this species than in temperate species. Some galls mature as early as late July and, after one or two generations of apterous adults, produce alates (emigrants) that migrate to bamboos [16, 89]. Live galls with alates are commonly found until December, and some until February [88]. Migration to bamboos therefore lasts over several months.

3.4.2. Pseudoregma bambucicola. Secondary-host generations of Pseudoregma bambucicola form dense colonies on bamboo shoots and twigs of Bambusa spp. The aphids are grayish brown in color, and the colony produces many first-instar, pseudoscorpion-like soldiers. In southern Japan (the Ryukyus, Kyushu and Shikoku), where the aphids on Bambusa multiplex have been studied by many researchers [90-99], the life cycle is anholocyclic (Figure 1(d)) - even though the colonies produce many sexuparae in autumnbecause its primary host, Styrax suberifolius, is absent.

In Taiwan, colonies of Pseudoregma bambucicola on bamboo produce alate sexuparae from November to February [88]. They fly to Styrax suberifolius, and their grandoffspring, fundatrices, transform flower buds into galls [100]. Incipient or very young galls (Figure 8(c)) have been found in May in both Taipei [88] and Puli [100]. Mature galls containing alates (emigrants) are found from early July to September in Puli [26]. Recent researches in Taipei revealed that some galls of $P$. bambucicola even last until May of the next year, or for almost one year [88]. The production of (secondinstar) soldiers in their galls [26] certainly contributes to the longevity of the galls. In the next section, we discuss a species whose galls last far longer than galls of $P$. bambucicola.

3.4.3. Ceratoglyphina styracicola. This aphid species has been recorded from Taiwan under the name of "Ceratoglyphina bambusae" [45, 89, 101-107]. However, the true C. bambusae is a tropical species, forming galls on Styrax fraserensis in the Malay Peninsula [31, 32]; its secondary-host generations (on bamboo) have been recorded from Sulawesi, Java, Sumatra, and the Malay Peninsula [32, 42, 54], but not in Taiwan. Mature galls (Figure 3(c)) of Ceratoglyphina styracicola are coated with wax and look entirely white, and the structure is very peculiar among aphid galls. Each gall consists of from one to a few subgalls that each look like a cauliflower's head. Ramified coral-like projections develop from the inner wall of each subgall, and they outgrow the original subgall's cavity to form the "head" outward [30]. Numerous aphids reside 


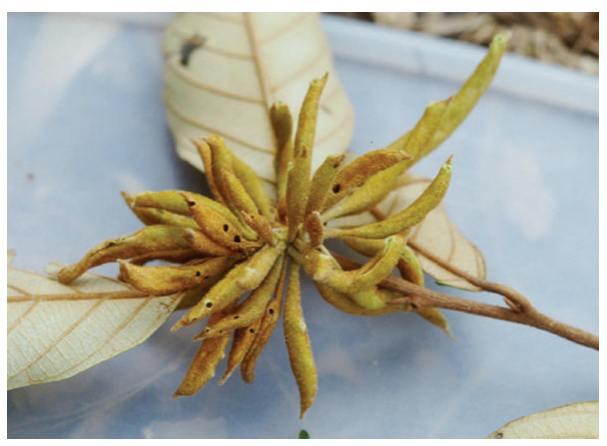

(a)

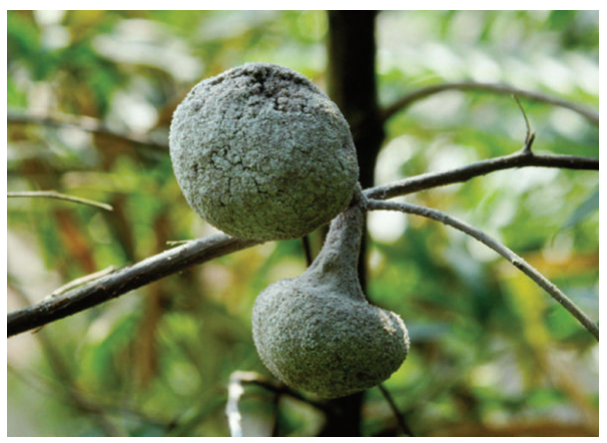

(c)

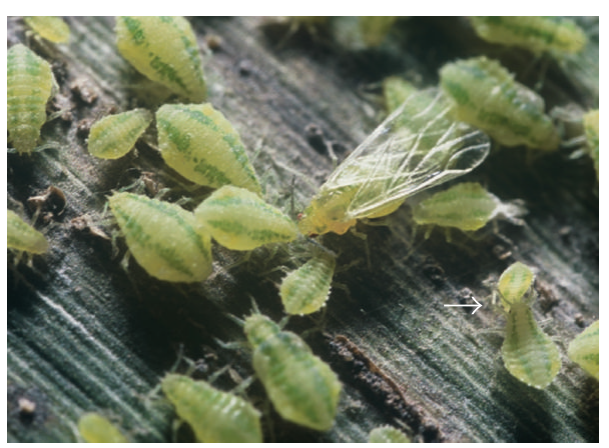

(b)

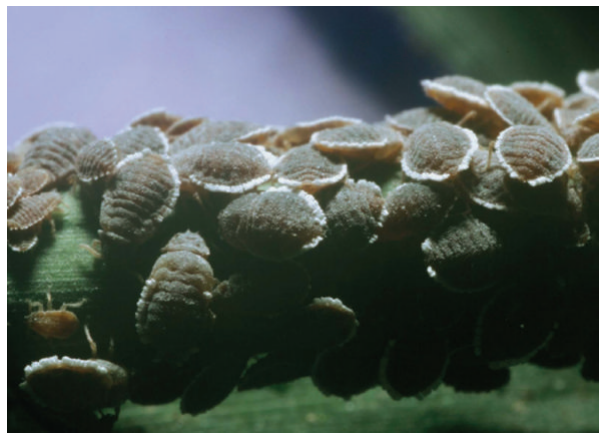

(d)

Figure 3: (a) A gall of Astegopteryx bambucifoliae (with many subgalls) on Styrax suberifolius (Sun Moon Lake, Taiwan; 25 September 1990). (b) A colony of A. bambucifoliae on a leaf of Bambusa sp.; a dueling pair is indicated by an arrow (Fushan, Taiwan; 22 April 2005). (c) A full grown gall of Ceratoglyphina styracicola (with two subgalls) on S. suberifolius (Sun Moon Lake; 13 December 1990). (d) A colony of C. styracicola on the bambusoid Pleioblastus sp. (Sun Moon Lake; 24 April 2005).

among these ramified projections. A large gall may contain 100,000 aphids, approximately half of which are soldiers [108]. Many soldiers reside on the outer surface of the gall, which is coated completely with wax, probably due to the soldiers' activity. These soldiers are highly aggressive, and pierce human skin with their stylets to cause troublesome irritation. When the colony size becomes huge, they even readily fall off the gall in response to disturbance [2, 108, 109].

The gall of Ceratoglyphina styracicola is initially formed by a single fundatrix on the stem of a developing shoot (Figure 8(b)) in July (or perhaps also in August) around Sun Moon Lake, central Taiwan. The gall grows very slowly and produces no alates within the first year. From the end of November of the next year, 16 months after the gall formation, the gall begins to produce alates that migrate to the bambusoid Pleioblastus sp. [89]. Once the production of alates begins, the gall continues to produce alates until its death, until the end of May at the latest. Thus, galls of $C$. styracicola can last for up to 23 months, although many die before. One young gall marked on 9 September 1992 was found alive on 25 May 1994, thus actually having lasted for 623 days, or about 20.5 months [30].

Migration from the Styrax galls to the secondary host occurs from the end of November to the end of May. On the other hand, colonies of C. styracicola on the secondary host (Figure 3(d)) produce many alate sexuparae around
Sun Moon Lake in the end of May and in June, which fly back to Styrax suberifolius. Some colonies on Pleioblastus sp. are found in September; so they probably also persist on the secondary host throughout the year. A few alate sexuparae have been found sporadically on the secondary host in December, February, and July [30]. It is unknown whether eggs produced in these months remain unhatched until July, or whether these alates are functionless.

3.5. Anholocycly in Subtropical and Tropical Asia. The sugarcane woolly aphid, Ceratovacuna lanigera, is a pest of sugarcanes (Saccharum spp.) and is widely distributed in tropical and subtropical regions of East Asia [70, 110]. The aphids also form colonies on leaves of the Chinese silver grass, Miscanthus sinensis [111, 112]. (In Taiwan, Takahashi [111] transferred apterae of $C$. lanigera from sugarcane to Miscanthus grass and vice versa "with very successful results.") Its distribution is extended to such a temperate region as Ichihara $\left(36^{\circ} \mathrm{N}\right)$, central Japan, where the aphids overwinter on $M$. sinensis outdoors [113]. Ceratovacuna lanigera is also famous for its defensive behavior, which will be treated in Section 5.4.6. Apterous adults (exules) of Ceratovacuna lanigera reproduce parthenogenetically throughout the year, and many alates are produced in various months $[112,114]$. Most of these alates are secondary migrants (i.e., migrants between sugarcanes or Miscanthus grasses). Alate sexuparae have been recorded in central Japan in 


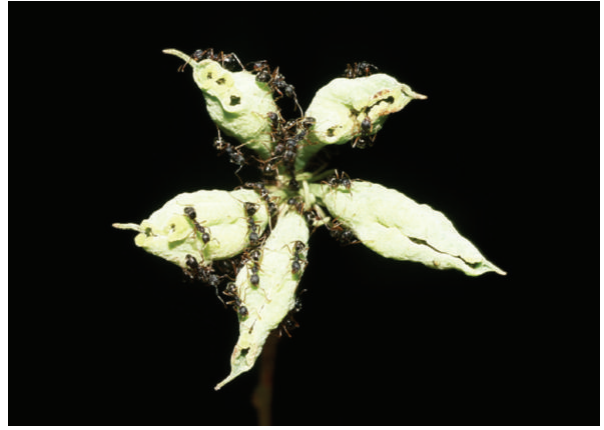

(a)

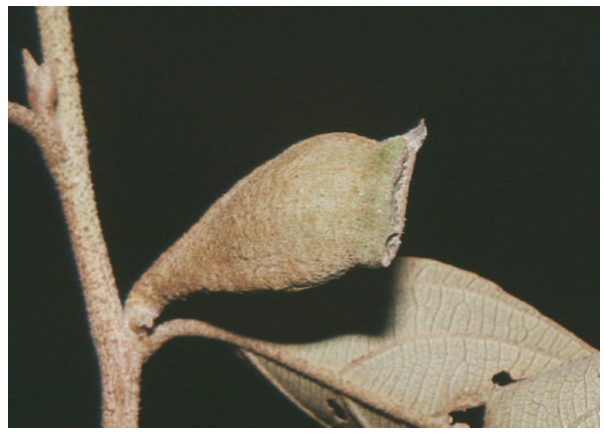

(c)

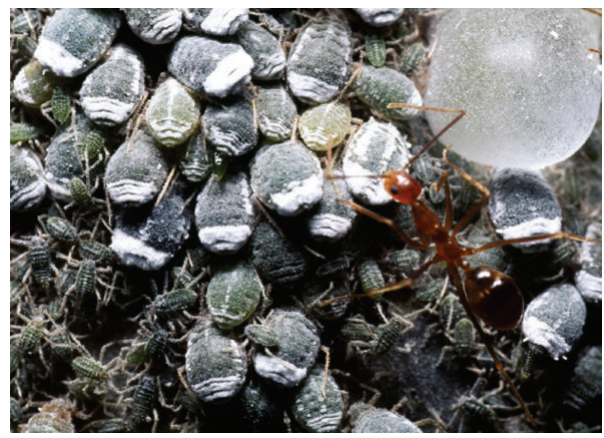

(b)

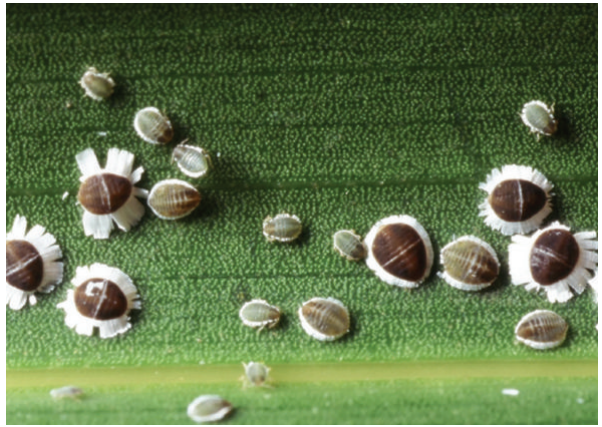

(d)

Figure 4: (a) A gall of Pseudoregma carolinensis on Styrax benzoides, with ants of Dolichoderus sp. (Chiang Mai, Thailand; 3 August 2000). (b) A colony of P. carolinensis on a bamboo shoot (Mae Sa, Chiang Mai Province, Thailand; 7 August 2000). (c) A gall of Cerataphis brasiliensis on Styrax benzoin (Tarutung, Sumatra; 3 March 1994). (d) A colony of C. brasiliensis on the palm Areca catechu (Bandar Baru, Sumatra; 28 August 1997).

autumn [115], and in Okinawa, southern Japan, from October to January and from April to June [116]. Although galls and associated generations are unknown, the species might retain its primary-host generations somewhere.

\subsection{Facultative Host Alternation in Tropical Monsoon Asia.} Until recently the tropical bamboo aphid Pseudoregma carolinensis has been confused with the subtropical aphid P. bambucicola $[117,118]$. Pseudoregma carolinensis is widely distributed in tropical Asia from Micronesia to India (recorded as "Oregma bambusae" [119] or "P. bucktoni" [120, 121]) and forms dense colonies on twigs and shoots of bamboo (Figure 4(b)). Its primary-host generation was found on the evergreen Styrax benzoides in and around Chiang Mai $\left(19^{\circ} \mathrm{N}\right)$, northern Thailand, where the rainy season (from the end of May to November) and the dry season (from December to the beginning of May) regularly alternate every year. Mature galls of $P$. carolinensis (Figure 4(a)), containing alate emigrants, were found in August [28]. Because the gall of $P$. carolinensis is made of a flower bud, the fundatrices initiate galls when flower buds appear, probably near the end of the dry season or early in the rainy season. Galls may not last for long after August, for no galls were found in November. It is very likely that its life cycle shows a clear seasonal pattern in northern Thailand.

In contrast to the gall generations, colonies on bamboo are found throughout the year, and alate sexuparae have been recorded in Chiang Mai Province in November and December. We also found some alate sexuparae in March in Chiang Mai (our unpublished observations). These sexuparae fly back to Styrax benzoides. It is not yet known whether earlyproduced eggs enter diapause or not.

As mentioned above, $P$. carolinensis is widely distributed in tropical regions of East Asia, beyond the range of Styrax benzoides. In Java, where the life cycle is probably anholocyclic, secondary migrants that disperse between bamboos occur [42].

In addition to $P$. carolinensis, two other species that form galls on Styrax benzoides, Astegopteryx bambusae and A. singaporensis, have facultatively host-alternating life cycles in tropical monsoon Asia (our observations in Chiang Mai). Their galls probably do not last beyond the severely dry months of March and April in northern Thailand.

3.7. Facultative Host Alternation in Equatorial Asia. In tropical rainforests of the Malay Peninsula and Sumatra, many species of cerataphidines form galls of various shapes on Styrax species, S. benzoin (Figures 4(c), 9, and 11(b)), S. paralleloneurus (Figures 6(c), 6(d), 12(b)), S. subpaniculatus (Figures $7(\mathrm{a})-7(\mathrm{c})$ ), and so forth. [8, 122, 123]. Also, their secondary-host generations are commonly seen on bamboos, palms, gingers, pothos, climbing pandanus, and mistletoes in and around the forest (our observations in Bandar Baru, Sumatra; see also [43]). The diversity and abundance of 
cerataphidines in these regions belie the widely held dogma of a paucity of aphids in the tropics (cf. [124, 125]). Most of these gall-forming cerataphidines have host-alternating life cycles, retaining a sexual generation $[10,19,29,31,34]$. However, it is not clear whether their galls are formed all the year round. Both mature and incipient galls of a single species are often found at the same time, but this may be merely because galls of the species last over a long period (cf. Section 3.4.3). Because trees in tropical rainforests are tall in general, no researchers have yet settled the issue by marking galls on Styrax trees there.

On its secondary host, Cerataphis brasiliensis produces scale-like aphids (Figure $4(\mathrm{~d})$ ), which are notorious as a pest of palms [126-128] and are widely distributed in tropical and subtropical regions of the world. The species has been recorded under the names of " $C$. palmae," " $C$. variabilis", and "C. fransseni," and, despite the valid species epithet brasiliensis, is of Southeast Asian origin. Its galls (Figure 4(c)) have been recorded from the evergreen Styrax benzoin in Java, Sumatra, and the Malay Peninsula [34, 42, $43,129,130]$. The fundatrix of $C$. brasiliensis transforms an axillary bud into its sac-like gall. It is therefore possible for fundatrices of the species to form galls whenever new shoots are developing. In the Malay Peninsula, galls have been recorded from June to August and from October to February [34]; in the other months no census has been made. In Ulu Gomback, Malaysia, incipient galls were found from October to January, together with mature galls [34]. These collection data suggest that galls of $C$. brasiliensis are formed irrespective of the season there. Unfortunately we do not know when alate sexuparae are produced on the secondary host in Malaysia. In Java, sexuparae were collected in September and October. Outsides the range of Styrax benzoin, where the life cycle should be anholocyclic, sexuparae are still produced and have been collected in March (Sri Lanka), from November to January (Surinam) and in July (Taiwan) [34]. These data are, however, not very informative for inferring the life cycle in the Malay Peninsula. Secondary migrants are commonly produced on palms both inside and outside the range of the primary host.

3.8. Non-Host Alternation on the Primary Host. Non-host alternation in aphids is often referred to as "monoecy." (The word has a completely different meaning in botany.) In the Hormaphidinae, these "monoecious" or non-hostalternating cycles have probably been derived from "heteroecious" or host-alternating cycles by discarding secondaryhost generations in some way. In the tribe Cerataphidini, five species that form galls on Styrax complete their life cycles without migrating to the secondary host, while retaining a sexual generation (Figure 1(c)). They are Tuberaphis styraci on Styrax obassia in Japan [39], T. leeuweni on S. subpaniculatus in Sumatra [40], T. owadai on S. tonkinensis in northern Vietnam [11], Ceratoglyphina roepkei on S. paralleloneurus in Sumatra [72], and Astegopteryx spinocephala on S. benzoides in northern Thailand [17]. Here we review the biology of three species.
3.8.1. Tuberaphis styraci. Tuberaphis styraci forms coralshaped single-cavity galls (Figure $5(\mathrm{a})$ ) on the temperate deciduous Styrax obassia in Japan. The monoecious life cycle of $T$. styraci is peculiar in that it is a biennial cycle [73].

Aoki and Kurosu $[39,73]$ studied the life cycle of this aphid at the Shomaru Pass $\left(36^{\circ} \mathrm{N}\right.$, ca. $600 \mathrm{~m}$ alt.), the Kanto District, Japan. The first-instar fundatrix hatches in May and forms a small, completely closed gall (Figure 5(b)) on the stem of a developing shoot of Styrax obassia. The gall grows slowly, and the fundatrix produces nymphs that become apterous adults. The colony size increases to approximately 30-100 individuals and the gall becomes globular and 4$10 \mathrm{~mm}$ in diameter at the end of the year. By that time the fundatrix dies, and the colony contains a number of soldiers but no alates are produced. Some galls have small openings, while others remain closed. After leaves of the host tree fall off, the gall, which looks somewhat like a winter bud of the host tree (Figure 5(c)), survives and overwinters in this stage. The mean temperature in Chichibu City near the Shomaru Pass is $1.6^{\circ} \mathrm{C}$ during January, the coldest month. (As mentioned in Section 2.3, galls of T. styraci were also found in Sapporo, where the mean temperature during January is $-4.1^{\circ} \mathrm{C}$.) At the Shomaru Pass, leaves of S. obassia begin unfolding in April, at which time the overwintered gall of $T$. styraci resumes growing (Figure $5(\mathrm{~d})$ ). The gall soon becomes large and coral shaped and has many small, exit holes (Figure 5(a)). The colony size reaches up to 15,000 [39], or 20,000, at times more than half of which are soldiers [131]. From late in July or August onward, alate sexuparae are produced. They fly to the undersides of leaves of S. obassia and produce sexuals there. Oviparous females lay eggs that overwinter, probably in fissures in the bark. The aphid colony in the gall can last until mid-October of the second year. The gall withers by the second winter and the dead, lignified gall remains for years on the tree.

We previously presented a hypothesis that this biennial, monoecious life cycle of Tuberaphis styraci may have been derived from an annual monoecious cycle [73]. However, it is now known that some host-alternating life cycles of Cerataphidini are accompanied by their long-lasting galls (Section 3.4.3). In the genus Tuberaphis, galls of T. taiwana, T. takenouchii, and T. coreana, all of which are host-alternating species, probably last for over one year (our unpublished observations). It is likely that an ancestor of $T$. styraci had such a host-alternating life cycle, and that the present life cycle of $T$. styraci has evolved by discarding the secondaryhost generation in some way.

3.8.2. Astegopteryx spinocephala. Astegopteryx spinocephala forms galls (Figure 6(a)) on the evergreen Styrax benzoides in Chiang Mai, northern Thailand, under the tropical monsoon climate. The fundatrix hatches around June, early in the rainy season, and initiates a gall on the stem of a developing shoot [17]. The gall grows slowly and reaches nearly its full size and becomes banana-bunch shaped by November but its subgalls are still closed at that time. In March/April, near the end of the dry season, a small ostiole appears near the tip of each subgall, and several ( 5 or 6 ) soldiers cooperate to plug 


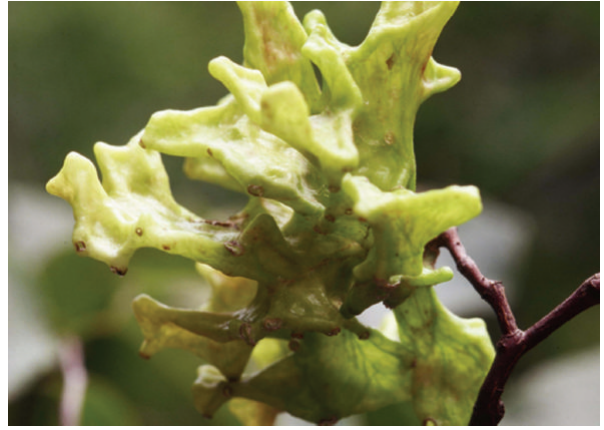

(a)

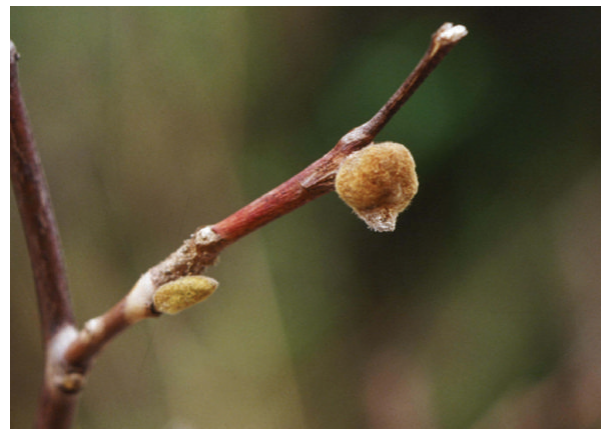

(c)

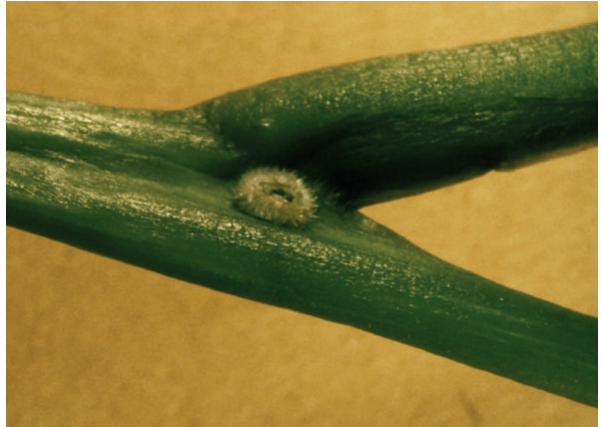

(b)

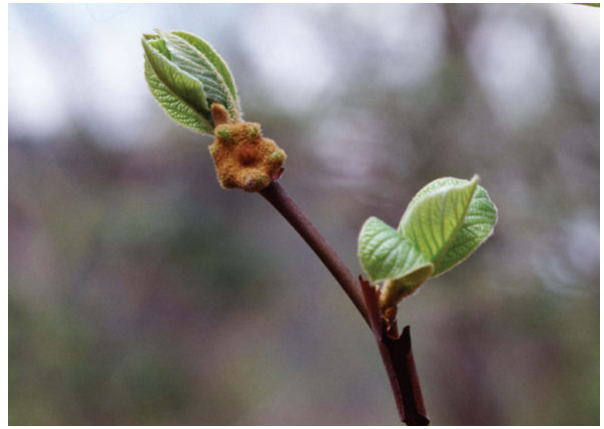

(d)

FIGURE 5: Galls of Tuberaphis styraci on Styrax obassia (Shomaru Pass, Japan). (a) A mature gall (15 July 1996). (b) An incipient (yet unclosed) gall on the stem of a developing shoot (23 May 1986). (c) A hibernating gall and a winter bud which has not yet burst (10 April 1989). (d) A hibernated gall that has resumed growing at the time of bud burst (17 April 1989).

the ostiole with their spiny heads from inside [132]. Alate sexuparae are produced in these months, and they crawl out of the subgall through the ostiole. Also in this season, many eggs (ca. 150-350 eggs per subgall [132], or ca. 2,500 eggs per gall [17]) are laid within subgalls (Figure 6(b)) and soldiers guard the eggs until they hatch in at least some galls. The mating system of A. spinocephala is peculiar among gall-forming aphids. Newly emerged sexuparae contain both female and male embryos. They deposit almost all female embryos (and some male embryos) within the natal subgall before flying to leaves of $S$. benzoides. After flying, they deposit the remaining embryos, almost all of which are males, on the undersides of the leaves. These first-instar males intrude into subgalls for mating despite that guarding soldiers try to prevent them from entering [133]. Such a mating system may have evolved because their galls remain viable until the next gall-forming season and can serve as safe concealments for eggs.

\subsubsection{Ceratoglyphina roepkei. Ceratoglyphina roepkei forms} one of the most remarkable galls (Figures 6(c) and 6(d)), which looks like a peruke with long curly frizzy hair, on the tropical evergreen Styrax paralleloneurus in Sumatra. The gall consists of several long, slender, tubular subgalls; each subgall is spirally twisted and has a longitudinal suture running from the base to the apex $[8,122,123,134]$. In Bandar Baru near Medan $\left(3^{\circ} \mathrm{N}\right)$, mature galls (Figure 6(c)) containing alate sexuparae were found in February [72]. As in Astegopteryx spinocephala, (at least some) eggs are laid within live subgalls (our unpublished observations). Many incipient galls of C. roepkei were found on the stems of developing shoots in April. From July to September, we found more-developed, yet immature galls (Figure 6(d)) but neither mature nor incipient galls at the same locality (our unpublished observations). Hence the life cycle of C. roepkei is seasonal there. On the other hand, Hille Ris Lambers [134] describes alates of C. roepkei based on specimens collected near Adian Koting $\left(2^{\circ} \mathrm{N}\right)$, midway from Sibolga to Tarutung, on 17 September 1931. The species therefore might produce alate sexuparae in different seasons at other localities.

\section{Gall Formation}

As mentioned before (Section 2.2), some groups (Cerataphis and Tuberaphis) of the Cerataphidini form singlecavity galls $[34,73]$, which are similar to those formed by Nipponaphidini, Hormaphidini, and other groups of aphids (e.g., [135]) in the basic structure and the process of formation. Others (Astegopteryx, Ceratovacuna, Ceratoglyphina, and Pseudoregma) form peculiar, multiple-cavity galls. The process of gall formation in the latter group is unique among aphids and will be explained in detail.

A gall is initiated by a single, first-instar fundatrix. When a fundatrix stimulates an appropriate part of the host plant by its stylets (and possibly also by its legs), plant tissues begin growing to cover the fundatrix and the fundatrix eventually 


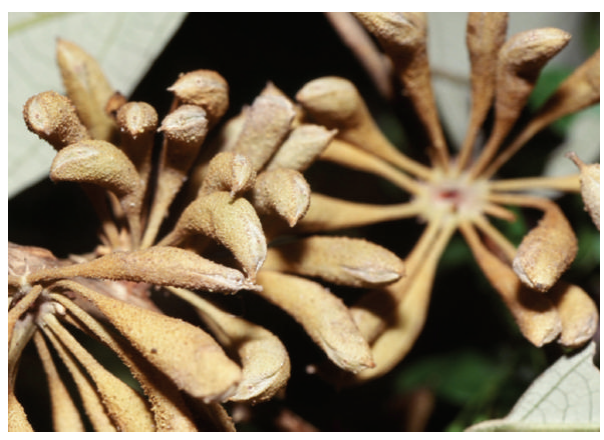

(a)

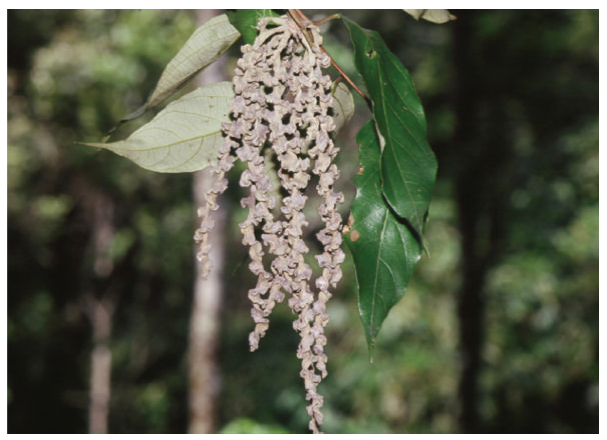

(c)

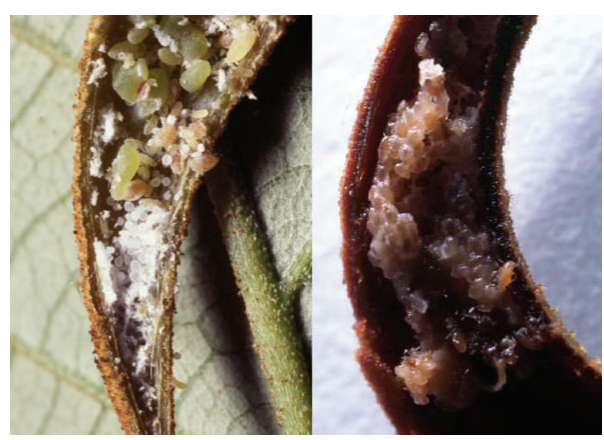

(b)

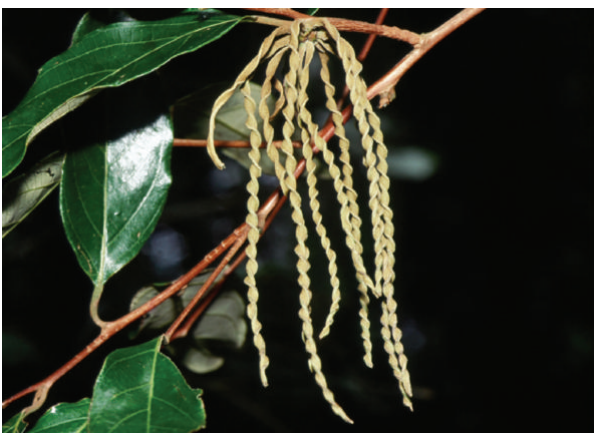

(d)

Figure 6: (a) Three galls of Astegopteryx spinocephala on Styrax benzoides (Chiang Mai, Thailand; 6 April 2000). (b) Cut subgalls of A. spinocephala (Chiang Mai; 6 April 2000): a live subgall (left) showing the inside, and another subgall after being submerged in alcohol (right) showing many eggs in its basal part (in the left photo, eggs are hard to see because they are covered with wax). (c) A mature gall of Ceratoglyphina roepkei on Styrax paralleloneurus (Bandar Baru, Sumatra; 24 February 1994). (d) A young gall of C. roepkei on S. paralleloneurus (Bandar Baru; 24 August 1997).

is confined in a closed cavity. The fundatrix becomes an adult and produces nymphs by parthenogenesis in the cavity. The colony in a Styrax gall therefore is a clone unless nymphs from other galls intrude into it (see Section 5.3.4).

4.1. Formation of Single-Cavity Galls. In the process of forming a single-cavity gall, the fundatrix is enclosed within the cavity until her death. The gall may later be ramified and look like a coral (Figures 5(a) and Figure 12(a)) or a bird nest (Figure 7(a)), but the single cavity is never partitioned into closed cavities (see Figure 7(b)). The gall may be made on the stem of a developing shoot, or of an axillary bud or a flower bud, or a latent bud.

4.1.1. Gall Formed on the Stem of a Developing Shoot. Galls of Tuberaphis styraci are formed on stems (Section 3.8.1). The fundatrix of T. styraci settles on the stem of a developing shoot of Styrax obassia. Soon the fundatrix is enclosed by tissues growing around it (Figure 5(b)). The gall swells later (Figure 5(c)) and in the next year becomes coral shaped (Figures 5(d) and 5(a)).

4.1.2. Gall Formed from a Flower Bud. Galls of Tuberaphis leeuweni are slender and tube-like (Figure 7(c)) and formed on inflorescences of Styrax subpaniculatus [40]. An illustration of its young galls by Docters van Leeuwen-Reijnvaan and
Docters van Leeuwen [8] clearly indicates that each gall is made of a flower bud. Aoki et al. [40] once mentioned that a calyx-like structure remains at the base of the gall, but we are now inclined to the opinion that the original sepals are abnormally stretched to form the entire gall. This possibility requires further investigation.

4.1.3. Gall Formed from an Axillary Bud. Galls of Cerataphis brasiliensis (Figure 4(c)) are initially formed on or from axillary buds of Styrax benzoin [34]. These incipient galls are simply enlarged to form sac-like galls. Galls of Cerataphis bambusifoliae are formed from axillary buds of Styrax suberifolius, probably in a similar way [33].

4.1.4. Gall Formed from a Latent Bud. Galls of Tuberaphis takenouchii (Figure 7(d)), which look like heads of broccoli, have exclusively been found on trunks or thick branches of Styrax japonicus [36, 136, 137] and S. formosanus [31, 37]. Young, small, sac-like galls have also been found on trunks and thick branches of S. formosanus in central Taiwan (our unpublished observations), indicating that the galls are formed from latent buds (i.e., those axillary buds whose development has been inhibited for years). Galls of Cerataphis jamuritsu are also found on thick branches of Styrax suberifolius (Figure 11(c)), suggesting that they are initiated on latent buds of the host tree [35]. 


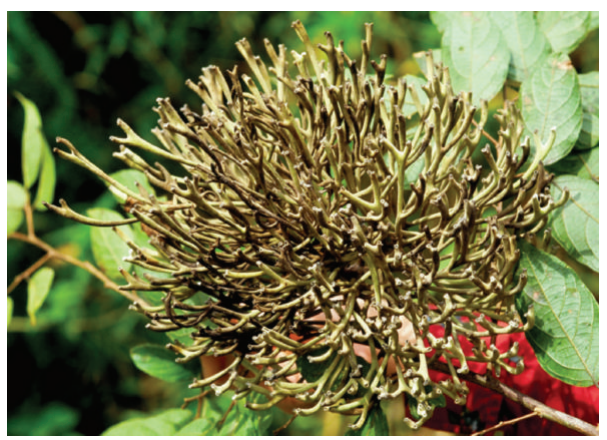

(a)

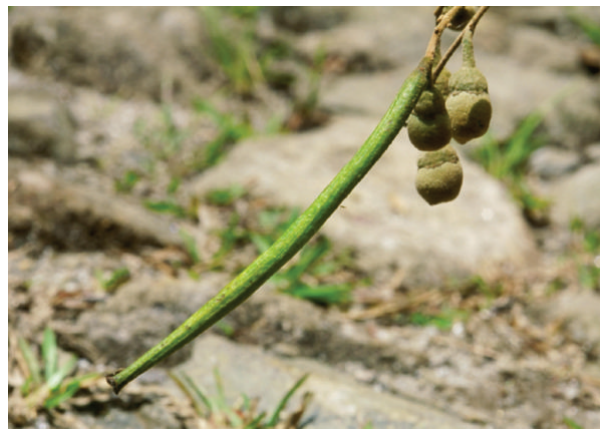

(c)

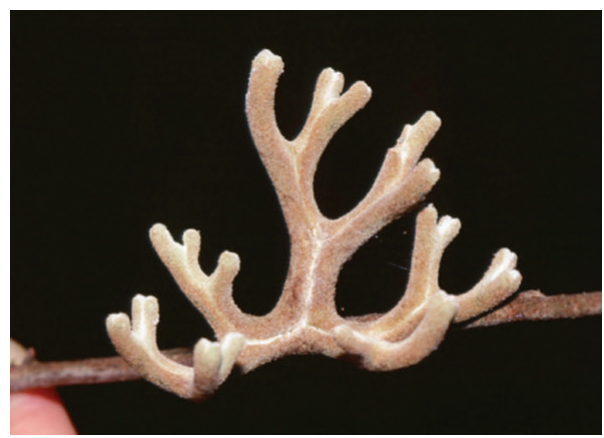

(b)

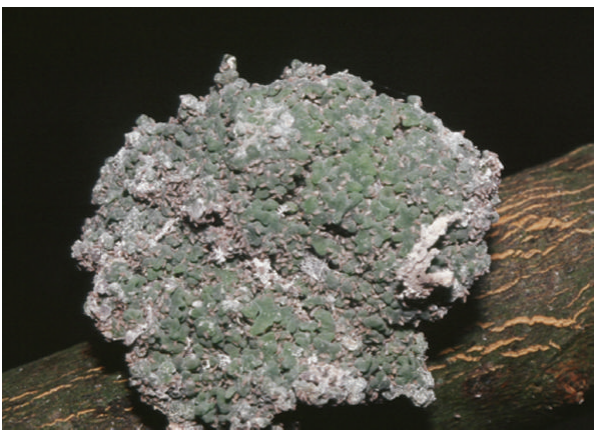

(d)

Figure 7: (a) A mature, well-ramified gall of Cerataphis vandermeermohri on Styrax subpaniculatus (Urung Tama, Sumatra; 12 September 1993). (b) A young gall of C. vandermeermohri on S. subpaniculatus, indicating that the ramified gall has a single cavity (Bandar Baru, Sumatra; 4 August 1996). (c) A tubular gall of Tuberaphis leeuweni on S. subpaniculatus and fruits of the host tree (Mt Sibayak, Sumatra; 19 September 1993). (d) A gall of Tuberaphis takenouchii on Styrax formosanus (upside down under natural conditions; Habon, Taiwan; 22 July 1994).

At times, galls of those species that usually form galls from axillary buds (e.g., Cerataphis brasiliensis) are found directly connected to thick twigs or branches [34]. This suggests that such species also utilize latent buds if available.

4.2. Formation of Multiple-Cavity Galls. Similar to the initiation of single-cavity galls, in the process of forming a multiple-cavity gall, the fundatrix is initially confined in a single cavity surrounded by lobes (Figures 8(a) and Figure 10(b)). Some of the lobes that enclose the fundatrix, however, are later differentiated into subgalls. First, inside the cavity, a niche appears on each of the lobes destined to be subgalls. At that time, the fundatrix has become an adult and begins to produce first-instar nymphs of the second generation. One or two first-instar nymphs enter each niche and begin feeding. Soon the nymphs in the niche are surrounded by plant tissues and confined in the newly formed cavity. Several subgalls are formed in this way, and the fundatrix is surrounded by the subgalls and a number of slender, solid projections which will not grow further (Figures 8(b) and 8(c)). The entire gall looks like a miniature "xiaolongbao" at this stage (Figure $8(\mathrm{c})$ ). The number of subgalls varies both between and within species, but it is common to all known species that the fundatrix never enters any subgall. In some species (e.g., Ceratoglyphina styracicola), a small pocket is formed at the bottom of the cavity of the entire gall and the fundatrix hides there [104]. As the subgalls, which are closed at this stage, grow outward, the entire gall opens (just as a flower opens from a bud) (Figure 8(d)) and the fundatrix is exposed again and left outside the closed subgalls. The fundatrix may still produce her offspring after all subgalls are closed. These firstinstar nymphs cannot enter any subgall and cannot grow to reproduce. They defend the closed subgalls from outside, probably against lepidopteran larvae that could bore into the subgalls [104, 138], and are called "outsiders" (outside defenders).

4.2.1. Gall Formed on the Stem of a Developing Shoot. Multiple-cavity galls of Astegopteryx bambucifoliae [16] (Figure 3(a)), A. spinocephala [17] (Figure 6(a)), A. malaccensis [8] (Figure 9(b)), Ceratoglyphina styracicola [104] (Figures 3(c) and Figure 8(b)) and C. roepkei (Section 3.8.3) (Figures 6(c) and 6(d)) are initially formed on stems of developing shoots of the host trees. Galls of Astegopteryx basalis (Figure 9(a)) are formed on the stem under the base of a leaf petiole [8], and those of A. spinocephala are sometimes formed under the base of a leaf petiole, too [17]. When these galls mature, they are firmly connected to the twig of the host tree. 


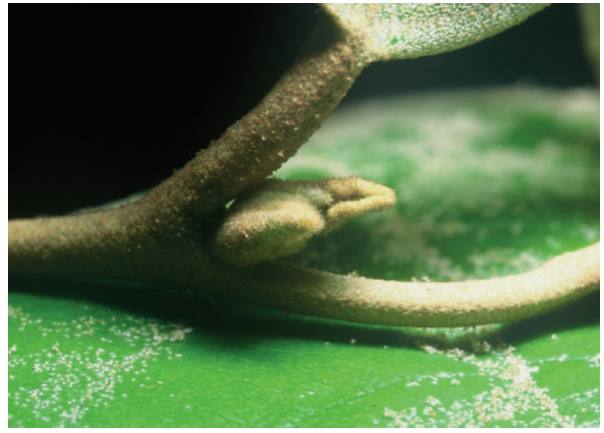

(a)

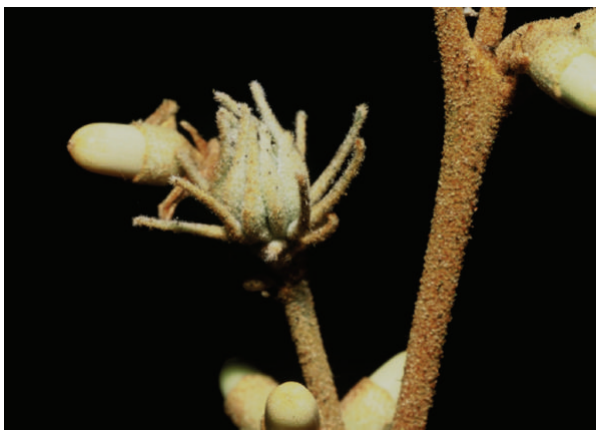

(c)

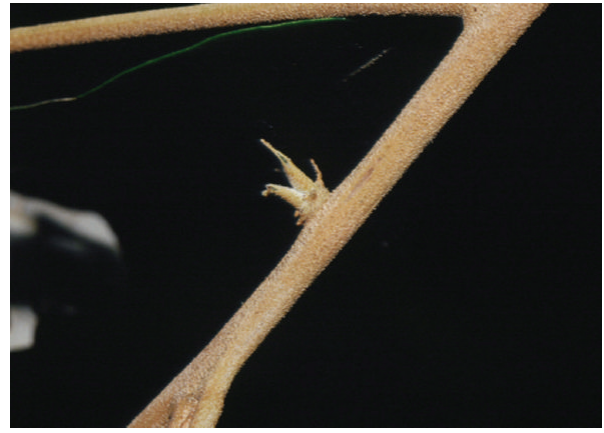

(b)

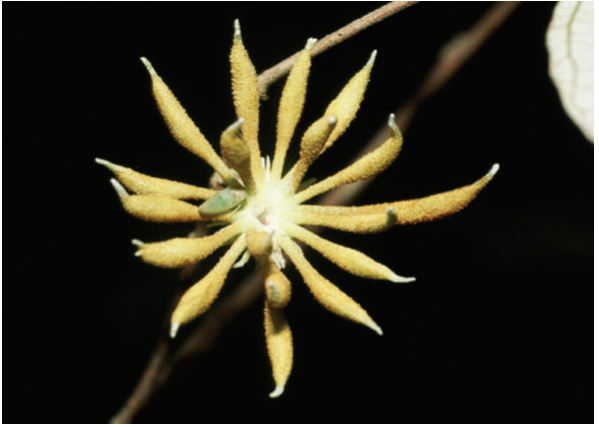

(d)

FIgURE 8: (a) An incipient gall of Pseudoregma koshunensis formed on an axillary bud of Styrax suberifolius (Taipei, Taiwan; 26 April 2005 ). (b) A very young gall of Ceratoglyphina styracicola formed on the stem of S. suberifolius (Sun Moon Lake, Taiwan; 18 July 1994). (c) A young gall of Pseudoregma bambucicola formed on an inflorescence of Styrax suberifolius (Fushan, Taiwan; 7 June 2004). (d) A young gall of Astegopteryx sp. on Styrax benzoides (Chiang Mai, Thailand; 1 August 2000).

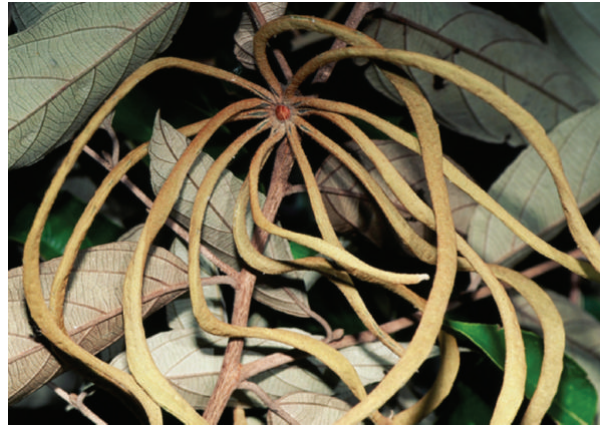

(a)

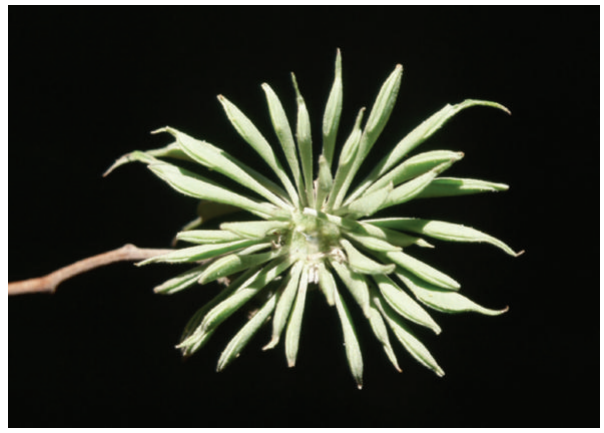

(c)

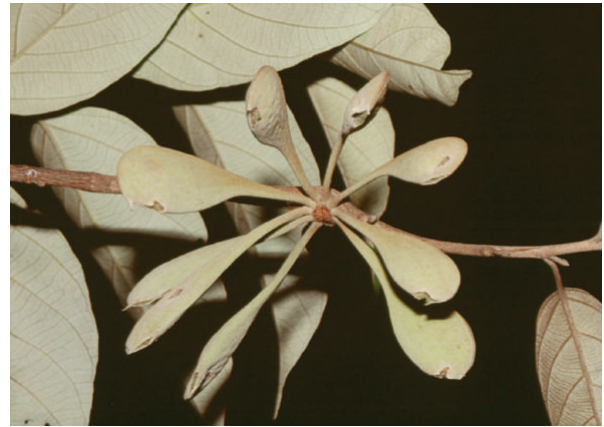

(b)

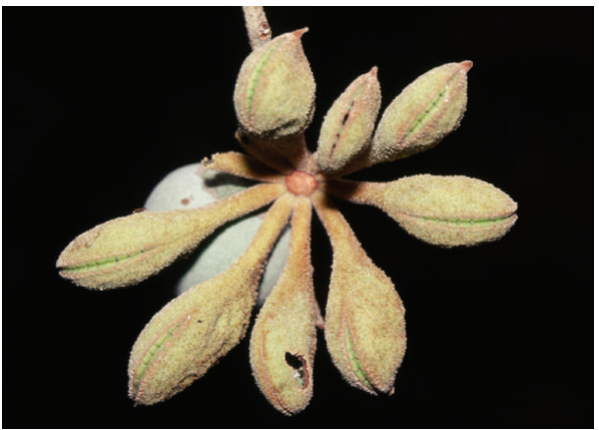

(d)

Figure 9: (a) A gall of Astegopteryx basalis on Styrax benzoin (Urung Tama, Sumatra; 21 August 1997). (b) A gall of Astegopteryx malaccensis on S. benzoin (Bukit Tinggi, Malay Peninsula; 31 March 1996). (c) A gall of Astegopteryx pallida on S. benzoin (Urung Tama; 1 August 1996). (d) A gall of Astegopteryx nipae on S. benzoin and a fruit of the host tree (Urung Tama; 1 August 1996). 
4.2.2. Gall Formed from a Flower Bud. Multiple-cavity galls of Astegopteryx styracophila [19] (Figure 11(b)), A. pallida [19] (Figure 9(c)), A. nipae (our unpublished observation) (Figure 9(d)), Pseudoregma bambucicola [100] (Figure 8(c)), P. carolinensis [28] (Figure 4(a)), and P. sundanica [29] (Figure 12(b)) are formed on inflorescences of the host trees. Because these galls each have a calyx-like structure at the base (see, e.g., Figure 1(a) in [100]), it is certain that each gall is made of a flower bud. In Section 4.2.5, we will argue that the use of flower buds for gall formation is an ancestral state in the group forming multiple-cavity galls. Although the use of flower buds has not been known from the genus Ceratoglyphina, one species of Ceratovacuna is known to form galls from flower buds on Styrax paralleloneurus in Sumatra (a gall shown as Figure 105 by Docters van Leeuwen-Reijnvaan and Docters van Leeuwen [25] turned out to be formed by Ceratovacuna sp. near keduensis; our unpublished observation).

4.2.3. Gall Formation from an Axillary Bud, without the Bud Shooting. Galls of Pseudoregma koshunensis (Figure 11(a)) are found at the positions of axillary buds of Styrax suberifolius, and we found some incipient galls (Figure 8(a)) formed on axillary buds. There is therefore no doubt that, as in the case of Cerataphis brasiliensis, the fundatrix transforms an axillary bud into the gall without causing the bud to develop into a shoot. (A few abnormal leaves sprout in the process of gall formation, but they may later be atrophied.) Latent buds may also be utilized for gall formation. Perhaps, some other species may form their galls in this way, but up to now, among multiple-gall formers, only P. koshunensis is known to do this.

\subsubsection{Gall Formation from an Axillary Bud, with the Bud} Shooting. The multiple-cavity gall of Ceratovacuna nekoashi (Figure 2(a)) is known as "Nekoashi" (cat's paw) among people living in Japan. The process of the gall formation is somewhat complicated. The host tree Styrax japonicus is deciduous and sheds all its leaves by winter in and around Tokyo. In spring, new shoots sprout from overwintered buds on the twigs. There are two kinds of new shoots. Shoots of one kind have inflorescences, and blossom in late May (Figure 10(a)). The shoots also have some (1-5) leaves (bracts), but there are no axillary buds at the bases of these leaves. Fundatrices of C. nekoashi cannot form their galls on these shoots. Shoots of the other kind have no inflorescences and continue to develop during the growing season, from spring to summer. As the shoots develop, they add one new leaf after another behind the terminal bud. Each leaf has an axillary bud at the base. Except when the shoot is damaged in some way, this axillary bud usually does not develop into a shoot until the next spring. (Axillary buds of Styrax formosanus in Taiwan rather commonly develop into shoots during the growing season.) The first-instar fundatrix of $C$. nekoashi transforms an axillary bud of a newly unfolded leaf into a small, incipient gall and conceals itself in it. The bud later becomes a multiple-cavity gall as explained before (Section 4.2), but at the same time the fundatrix causes the bud to develop into a shoot, with the gall being located at the terminal position of the shoot [21] (Figures 10(b) and $10(\mathrm{~d}))$. The fundatrix of $C$. japonica forms its gall in basically the same way [20]. Sometimes a fundatrix of $C$. nekoashi succeeds in causing an axillary bud to develop into a shoot but dies before producing its offspring in the incipient gall. In this case, the incipient gall is not developed into a normal multiple-cavity gall but often transformed into a single flower [21] (Figures 10(c) and 10(d)). What this fact implies is discussed in the next section. These single flowers originating from failed galls are noticeable because they bloom after all normal blossoms fall off the tree. According to Deguchi [139], who suggested for the first time that such single flowers of Styrax japonicus may be caused by $C$. nekoashi, the number of petals and the number of stamens in these flowers are often different from those in normal flowers (five petals and ten stamens). Some single flowers even have double petals [21]. At times, single flowers bore a fruit [21], which, however, may be abnormal in structure [140].

Such abnormal flowers, or "gall flowers," have also been recorded from Styrax formosanus. We found a gall flower on S. formosanus near a gall of Ceratovacuna nekoashi (our observation around Sun Moon Lake, Taiwan, on 24 April 2005). In other two cases, both an abnormal flower and a live gall of Ceratovacuna sp. appeared at the tip of the same petiole originating from a single axillary bud of $S$. formosanus (our observations around Sun Moon Lake on 21 April 1990).

4.2.5. Genetic Hacking Hypothesis. A multiple-cavity gall of the Cerataphidini resembles a Styrax flower in its radially symmetric structure. The fact that a failed gall of Ceratovacuna nekoashi is often transformed into a single flower suggests that the fundatrix may exploit the mechanism of flower formation in the host plant for its gall formation. That is, the fundatrix may induce differentiation of floral meristems that would otherwise become petals and stamens (and possibly also a pistil) into subgalls. According to this hypothesis, the ancestor of the multiple-gall formers used to directly utilize a flower bud for gall formation, as the fundatrices of some extant species such as Astegopteryx styracophila and Pseudoregma bambucicola do (Section 4.2.2). Later, fundatrices of some species may have acquired the ability to form galls from other than flower buds, that is, axillary buds or stems of developing shoots, by causing differentiation of undifferentiated meristematic tissues into floral meristems. It is tempting to speculate that the fundatrices might inject a substance that activates the expression of floral meristem identity genes including $L E A F Y$ (see $[141,142]$ ) into the plant to do this, thus hacking an epigenetic regulation system of flowering.

In this connection, it will be interesting to know whether gall flowers are caused by those multiple-gall formers that induce their galls on stems (Ceratoglyphina and some species of Astegopteryx) or axillary buds without the bud shooting (Pseudoregma koshunensis).

4.3. Hardening of Gall Walls. The walls of cerataphidine galls are generally not very hard. However, in Cerataphis 


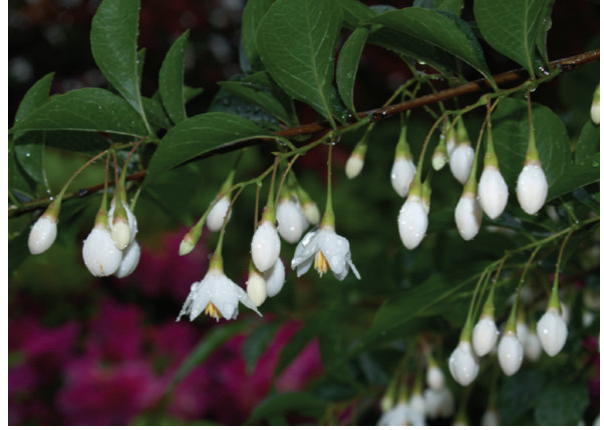

(a)

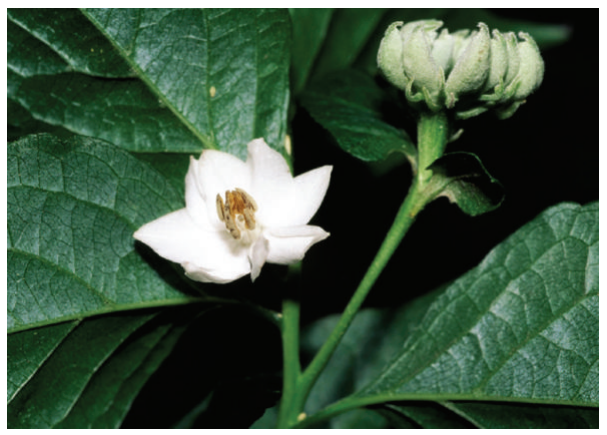

(c)

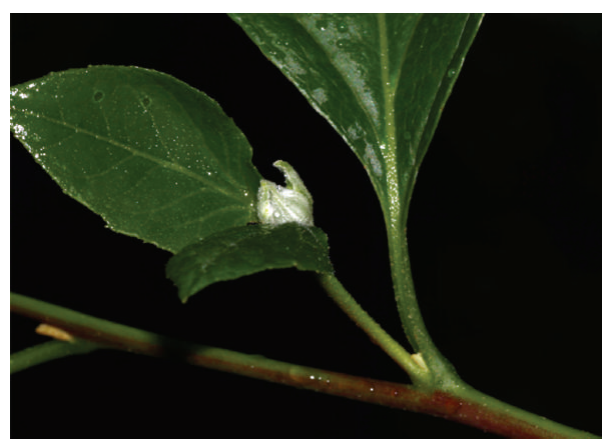

(b)

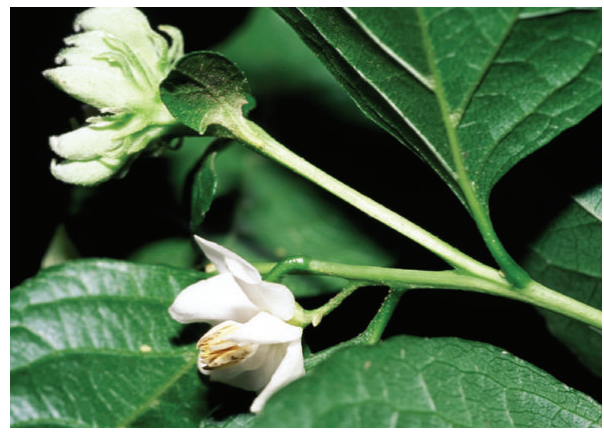

(d)

FIGURE 10: (a) Normal flowers (with five petals) of Styrax japonicus (Niiza, Japan; 6 May 2009). (b) A "gall shoot" that has sprouted from an axillary bud of S. japonicus, with a young gall of Ceratovacuna nekoashi at the apex, two bract-like leaves, and a new axillary bud at the base (Niiza; 6 May 2009). (c) A gall of C. nekoashi and an abnormal flower (with more than five petals) of S. japonicus (Niiza; June 1999). (d) The same abnormal flower shown from a different angle, indicating that it has sprouted from an axillary bud; petioles of abnormal flowers are variable in length and at times also with bracts (which are absent on this gall-flower shoot).

brasiliensis [34, 130] and Pseudoregma koshunensis [143] (Figure 11(a)), the walls of their galls become lignified and hard. In Astegopteryx styracophila, the apical wall of each subgall is thick and hard like a cork stopper [19] (Figure 11(b)). The hardest galls are made by Cerataphis jamuritsu on Styrax suberifolius $[35,136]$ (Figure 11(c)). One large gall of this species had a wall that was strongly lignified and approximately 5.8-12.1 mm thick (Figure 11(d)), and Aoki et al. [35] had to saw the gall to open it.

4.4. Coating of Gall Surface with Wax. Gall-living generations of cerataphidines, including soldiers, produce wax. Honeydew excreted by the aphids is coated with the wax to form droplets (see Figures 6(b) and 12(f)), or "aphid marbles" [144], and soldiers push them out of the gall without being trapped in the honeydew [28, 39, 131, 132, 145]. In species whose soldiers reside on the outer surface of their gall, the surface is coated with wax due to the activity of the soldiers. The outer surfaces of the galls of Tuberaphis owadai [11] (Figure 12(a)), T. sumatrana (our unpublished observation), and Cerataphis bambusifoliae [33] look silvery grey, and those of Ceratoglyphina styracicola [102] (Figure 3(c)), Cerataphis jamuritsu [35] (Figure 11(c)), and Pseudoregma sundanica [29] (Figure 12(b)) look snow white. The wax coating no doubt functions to be water repellent. The outer surfaces of the galls (e.g., of Tuberaphis owadai and Ceratoglyphina styracicola) are densely covered with minute hairs which are likely to accumulate wax powder.

4.5. Utilization of Projections from the Inner Gall Wall. Among cerataphidine galls, the galls of Ceratoglyphina styracicola [2] and Tuberaphis takenouchii [36, 137] are peculiar in structure. The former is a multiple-cavity gall, while the latter a single-cavity gall. In both species, most aphids reside among twiggy projections which constitute the head(s) of their gall or subgalls (Figure 12(c)), rather than inside the original cavity or cavities, after the gall reaches some size. How the head of a (sub)gall is formed is similar between the two species. Here we describe the case of $C$. styracicola [30].

A young gall of Ceratoglyphina styracicola consists of a few spindle-shaped subgalls, which are hollow. The inner wall of each subgall is initially smooth but, as the subgall grows, small solid projections are developed from the inner wall. These projections become ramified and soon fill the cavity (Figure 12(e)). They grow further, outward through the apical slit to form the subgall's head, which may be up to $7-10 \mathrm{~cm}$ in diameter $[2,101,108]$ when fully developed (Figure 3(c)). The outermost sides of these projections bear minute hairs (but do not in Tuberaphis takenouchii) and catch wax, and the entire gall looks white, as mentioned in the previous section. 


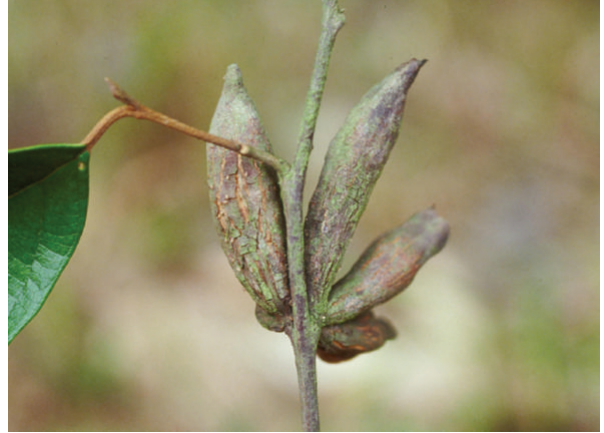

(a)

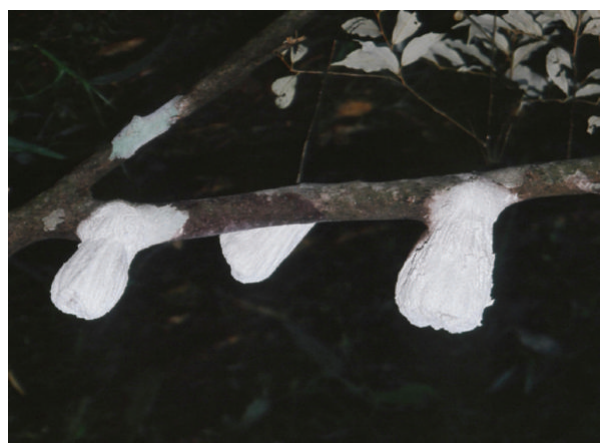

(c)

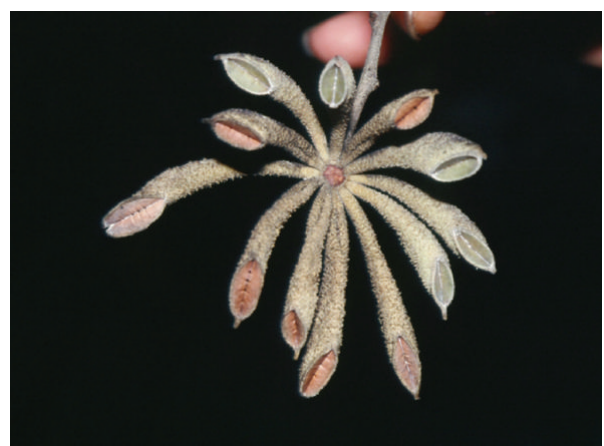

(b)

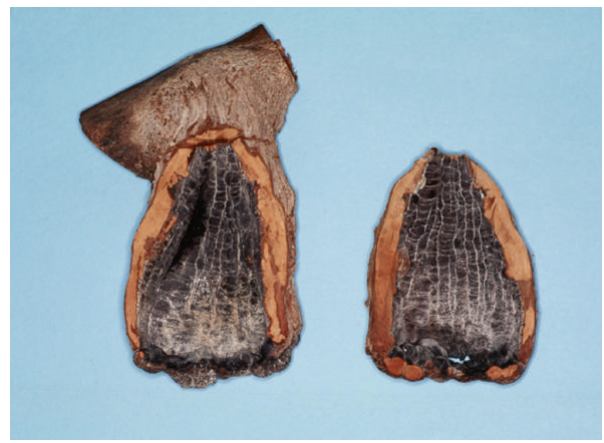

(d)

Figure 11: (a) A lignified (live) gall of Pseudoregma koshunensis on Styrax suberifolius (Sun Moon Lake, Taiwan; 3 June 1992). (b) A gall of Astegopteryx styracophila on Styrax benzoin (Urung Tama, Sumatra; 28 February 1994). (c) Three galls of Cerataphis jamuritsu on a thick branch of S. suberifolius (Hsinhua, Taiwan; 3 November 1994). (d) A cut gall of C. jamuritsu, indicating its thick wall (the rightmost gall in (c); dried after being kept in ethanol).

When part of the head is broken, the broken part may be nearly completely or partially repaired through the regrowth of projections [101]. Live, deformed galls of C. styracicola, which seem to have been broken by vertebrates, are often observed in the field [101]. In the gall of Pseudoregma sundanica, projections developed from the inner wall usually do not grow out of the subgall (see Figure 12(b) and below). However, we once found a subgall (Figure 12(d)) that looked just like a gall of T. takenouchii. The original gall wall was largely broken, and hyper-growth of projections formed the head. Gall repair is now known in two other aphid species belonging to the Nipponaphidini $[146,147]$ and Pemphigini [148].

The inner walls of subgalls of Ceratovacuna nekoashi (our unpublished observations), C. japonica [20], Astegopteryx bambucifoliae [16], Pseudoregma bambucicola [26], and $P$. carolinensis [28] are almost smooth with no or only a few short projections. On the other hand, there are many short projections on the inner walls of subgalls of Astegopteryx styracophila [19], A. pallida [19], A. spinocephala [17] (Figure 6(b)), and A. nipae (Figure 12(f)), and several, somewhat developed projections on those of Pseudoregma sundanica [29] (Figure 12(b)). These projections not only provide mechanical support for the structure but also increase the area of feeding sites for aphids. Thus, mature galls of Ceratoglyphina styracicola, consisting of well-developed ramified projections, can often sustain more than 100,000 aphids [2, 108]. Among cerataphidines that form singlecavity galls, only Tuberaphis takenouchii has yet been known to form galls with such projections.

\section{Morphs}

Aphids basically undergo cyclic parthenogenesis, in which a number of asexual generations are interrupted by a single sexual generation. As is well known, the phenotypes of aphids vary between generations of a single species. In Cerataphidini, aphids produced on the primary host are so different in appearance from those produced on the secondary host that they were once placed in different genera. The former had been grouped under the genus name "Astegopteryx," while the latter under the names of "Cerataphis," "Oregma", and "Ceratovacuna" until Shibata $[149,150]$ and Hille Ris Lambers [151] showed that they are alternative morphs of the same group of species. In addition, nymphs are also polyphenic between and even within generations.

5.1. Fundatrix. The fundatrix is the sexually produced generation. First-instar fundatrices of cerataphidines are gallinitiators. We have examined those of Ceratovacuna nekoashi [21], C. japonica [20], Pseudoregma bambucicola [100], P. koshunensis (our unpublished observation), Astegopteryx 


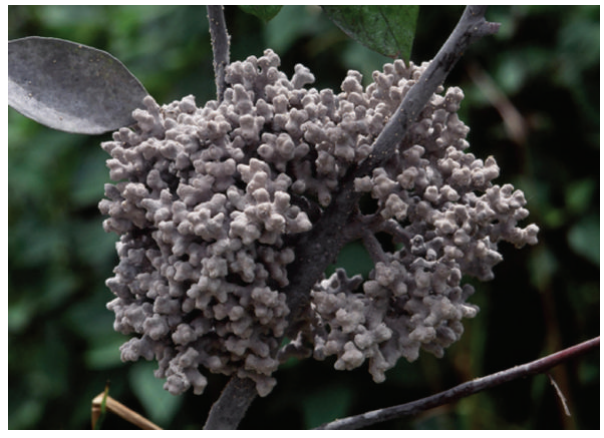

(a)

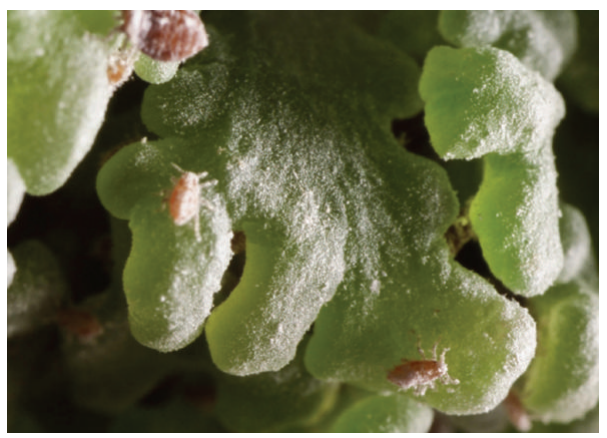

(c)

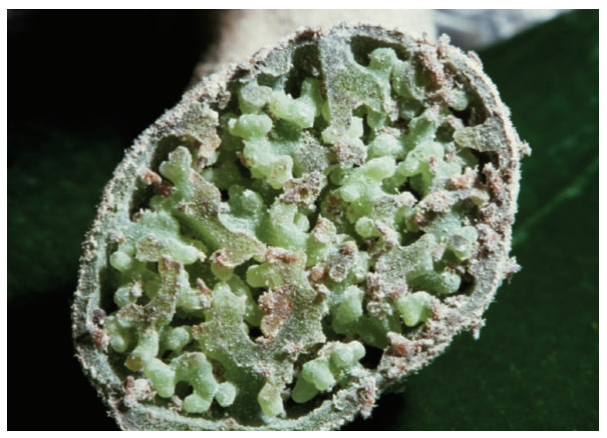

(e)

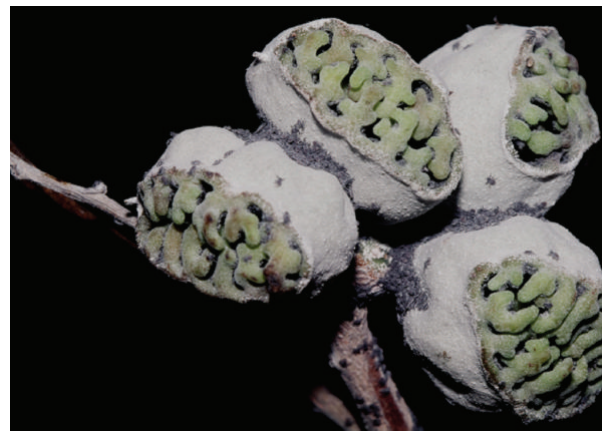

(b)

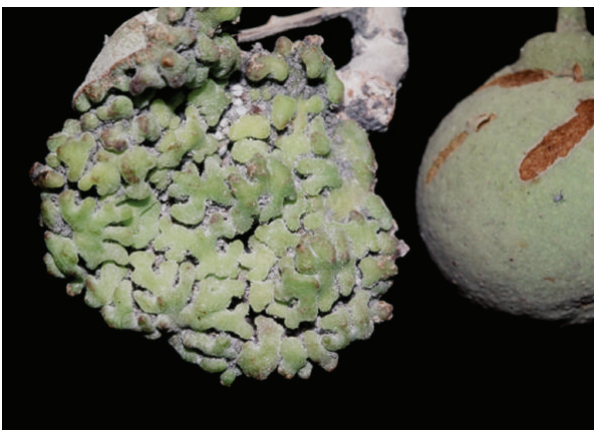

(d)

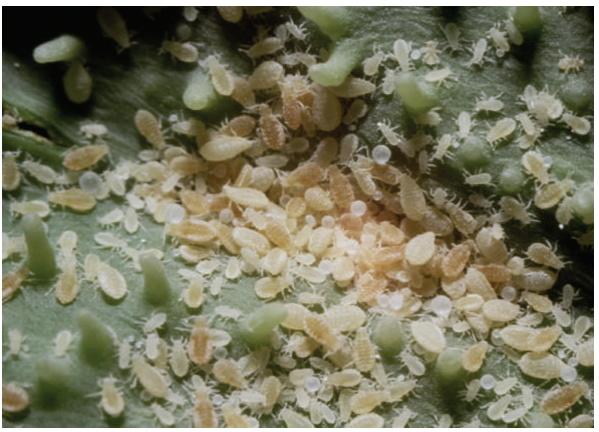

(f)

Figure 12: (a) A gall of Tuberaphis owadai on Styrax tonkinensis (Pha Din, Vietnam; 12 September 1995). (b) A gall of Pseudoregma sundanica on Styrax paralleloneurus; many soldiers (dark gray in color) reside on the outer surface of the gall, mainly on the basal parts of the subgalls (Mt Sibayak, Sumatra; 2 August 1996). (c) Outer surface of a gall of Tuberaphis takenouchii on Styrax formosanus; aphids live among ramified solid projections (Habon, Taiwan; 4 November 2003). (d) A once-broken gall of P. sundanica on S. paralleloneurus and a fruit of the host tree (Mt Sibayak; 2 August 1996). (e) A cut subgall of Ceratoglyphina styracicola on Styrax suberifolius, showing ramified solid projections developing inside (Sun Moon Lake, Taiwan; July 1986; photo by N. E. Pierce). (f) A cut subgall of Astegopteryx nipae on S. benzoin, showing short solid projections (Gombak Rd., Malay Peninsula; 2 December 1992; photo by D. L. Stern).

bambucifoliae [16], A. spinocephala [17], Ceratoglyphina styracicola [104], Tuberaphis styraci [73], and Cerataphis brasiliensis [34]. These first-instar nymphs are characterized by well-sclerotized tergites with long setae, well-developed setae on the tarsi, and the long, slender ultimate rostral segment. In at least one species (C. nekoashi), first-instar fundatrices are known to fight each other for a gall-forming site [21].

Upon feeding on the host plant, the first-instar fundatrix is soon enclosed by plant tissues (Section 4). After the first molt, its tergites become membranous and its rostrum becomes shortened. The adult fundatrix (which is apterous) also has membranous tergites and no cornicles. In species forming single-cavity galls, the fundatrix lives with its progeny in one and the same cavity. In species forming multiple-cavity galls, the fundatrix does not enter any subgall (Section 4.2). Unlike many aphids, cerataphidine fundatrices are not very fecund. For instance, fundatrices of Ceratovacuna nekoashi give birth to only eight to 21 offspring [138]. In contrast, a single fundatrix of Grylloprociphilus imbricator (Eriosomatinae, Pemphigini) may produce more than 7,000 nymphs [152]. 
5.2. Fundatrigeniae. The parthenogenetic generations following the fundatrix on the primary host are called "fundatrigeniae." In the gall, a number of (fundatrigenia) generations follow in succession, depending on how long the gall lasts. Adult fundatrigeniae can be winged (alate) or wingless (apterous), but alates are produced only after the gall matures, when the colony size is from $10^{2}$ to $10^{5}$ (Table 3). Alates that fly to the secondary host are called "emigrants," while those that deposit sexuals on the primary host are "sexuparae" (Section 5.5).

5.2.1. Second Generation. The second generation, or the direct offspring of the fundatrix, plays a special role in the species forming multiple-cavity galls. They become founders of subcolonies in subgalls (Section 4.2). The number of founders per subgall is different between species, one in Astegopteryx spinocephala [17], one to three (mean 1.2) in Ceratovacuna nekoashi $[21,138]$, and one or two (mean 1.1) in Ceratoglyphina styracicola [104]. Late-born firstinstar nymphs of the second generation often cannot enter subgalls because all subgalls may have been closed by that time. They defend their young gall outside the subgalls and are functionally sterile. This is the case for Ceratovacuna nekoashi [138] and Ceratoglyphina styracicola [104]. In Astegopteryx bambucifoliae, however, new subgalls are continuously formed over a relatively long period. It is therefore likely that late-born nymphs still can enter subgalls and may not be destined to die without growing. In fact, the number of subgalls is from five to 12 in Ceratovacuna nekoashi [138] and only three to six in Ceratoglyphina styracicola [30, 104], but up to 32 in A. bambucifoliae [16]. At least in Ceratovacuna nekoashi [138] and C. japonica [20], the outsiders are not different in morphology from the firstinstar nymphs that have entered subgalls. Not only outsiders but also nymphs that have entered subgalls attack potential predators when the subgall is broken [20].

5.2.2. Third and Later Generations. Aphids of the third or later generations are not very different from those of the second generation in morphology but are generally larger than the latter [104]. While apterous adults of the second generation may not have cornicles (siphunculi) in some species forming multiple-cavity galls, those of the third and later generations always have a pair of ring-like cornicles on the sixth abdominal tergite. (Cornicles of cerataphidines are mere pores and not horn shaped, but still are referred to as "cornicles" in aphidology.) In the fundatrigenia generations, sterile soldiers appear in the second instar. The first-instar nymphs of these generations are monomorphic and, past the first molt, they develop into either "normal" second-instar nymphs or sterile soldiers. The second-instar soldiers are described in Section 5.3. The normal second-instar nymphs develop into apterous or alate adults after three more molts. (Adults are in general fifth-instar aphids.) Except for alate adults, these non-soldier fundatrigeniae may attack potential predators and/or pierce human skin with their stylets (e.g., [108]). They probably function as auxiliary defenders. Apterous adults, of course, reproduce in the gall or subgall. Alates fly to the secondary host (if the life cycle is host-alternating) or to Styrax trees (if the life cycle is nonhost-alternating) and give birth to their offspring on the undersides of the leaves $[27,89]$.

5.3. Soldiers on the Primary Host. All cerataphidine species whose gall-generations are known produce second-instar soldiers in their galls on the primary host. Although some authors $[6,7]$ use the word "soldiers" to include any defensive individuals, in the present review we use it to denote a morphological caste whose primary function is colony defense. Non-soldier individuals that play a defensive role are referred to as "defenders" or "defensive nymphs."

5.3.1. Morphology. The soldiers are morphologically different from the normal second-instar nymphs (reproductivesto-be) in having sclerotized tergites with longer setae, longer claws, protruded cornicles, and one or more pairs of spinelike setae on the frons. In the genus Pseudoregma, the forelegs are thickened $[26,28,29,153]$ as in the first-instar soldiers produced on the secondary host (see Section 5.4.2). In Astegopteryx pallida (reported as A. "setigera" [42]) and A. spinocephala [132], the soldiers are armored with many spines on their heads. The number of these frontal spinelike setae is usually one pair in Cerataphis and Tuberaphis (e.g., $[35,39]$ ), while more than one pair in Astegopteryx, Ceratovacuna, Pseudoregma, and Ceratoglyphina (e.g., [2, 16, 20, 28]). In Ceratovacuna nekoashi, however, these multiple pairs of frontal setae are not distinctly spine-like (our unpublished observations).

5.3.2. Defensive Behavior. The second-instar soldiers clasp an insect predator such as a moth larva and pierce it with their stylets. Such attacking behavior has been confirmed by us for almost all aforementioned species through introducing an insect larva into (or onto) the gall (e.g., [108]). The only exception was Tuberaphis leeuweni. Aoki et al. [40] failed to induce attacking behavior from its soldiers. The second-instar soldiers of all cerataphidine species we have examined so far (including T. leeuweni) pierce human skin, which causes irritation of various degrees. The irritation caused by soldiers of Ceratoglyphina styracicola is fairly severe $[2,108,109]$. We were not able to continue field observations without brushing off the soldiers that were piercing the skin on our hands. The irritation caused by soldiers of Tuberaphis sumatrana (U. Kurosu, her experience) and Cerataphis vandermeermohri $[10]$ is as severe as by soldiers of C. styracicola. In contrast, soldiers of Tuberaphis styraci [39], T. taiwana [38], and T. leeuweni [40] cause irritation in only a slight degree. The irritation caused by soldiers of other species, including Ceratovacuna japonica [20], Cerataphis jamuritsu [35], Pseudoregma bambucicola [26], Tuberaphis owadai [11], and Astegopteryx spinocephala [132], falls between these two extremes. Soldiers of two species, Ceratoglyphina styracicola and Cerataphis vandermeermohri, readily fall off their gall when the gall is lightly shaken manually $[2,10,108]$. (This happens only when the gall and the colony size are large enough.) This is interpreted 
TABLE 3: Colony size and the percentage of soldiers in cerataphidine galls.

\begin{tabular}{|c|c|c|c|}
\hline Species & Colony size $^{1}$ & \%Soldiers & References \\
\hline Ceratoglyphina styracicola & $100,000 \sim 200,000(n=2)$ & $43 \sim 55 \%$ & {$[2,108]$} \\
\hline Tuberaphis owadai & $60,000 \sim 180,000(n=2)$ & $41 \sim 52 \%$ & {$[11]$} \\
\hline Cerataphis vandermeermohri & $8,000 \sim 94,000(n=3)$ & $44 \sim 46 \%$ & {$[10]$} \\
\hline Cerataphis jamuritsu & $18,000 \sim 57,000(n=2)$ & $46 \sim 48 \%$ & {$[35]$} \\
\hline Tuberaphis taiwana & $5,000 \sim 18,000(n=3)$ & $27 \sim 42 \%$ & {$[38]$} \\
\hline Tuberaphis styraci & $8,000 \sim 15,000(n=3)$ & $29 \%(n=1)$ & {$[39]$} \\
\hline Pseudoregma sundanica & $2,000 \sim 15,000(n=7)$ & $45 \sim 60 \%$ & [29] \\
\hline Astegopteryx styracophila & $1,400 \sim 12,000(n=3)$ & $24 \sim 38 \%$ & [19] \\
\hline Cerataphis bambusifoliae & $2,900 \sim 9,800(n=5)$ & $21 \sim 48 \%$ & [33] \\
\hline Astegopteryx pallida & $1,500 \sim 9,000(n=3)$ & $30 \sim 46 \%$ & {$[19]$} \\
\hline Cerataphis brasiliensis & $6,400(n=1)$ & $25 \%$ & {$[34]$} \\
\hline Astegopteryx spinocephala & $2,300 \sim 6,200(n=2)$ & $59 \sim 63 \%$ & {$[17]$} \\
\hline Astegopteryx bambucifoliae & $100 \sim 5,300(n=4)$ & $21 \sim 64 \%$ & [16] \\
\hline Ceratovacuna japonica & $400 \sim 1,700(n=5)$ & $15 \sim 45 \%$ & {$[20]$} \\
\hline Pseudoregma bambucicola & $300 \sim 1,600(n=8)$ & $23 \sim 41 \%$ & {$[26]$} \\
\hline Pseudoregma carolinensis & $500 \sim 1,500(n=6)$ & $45 \sim 66 \%$ & {$[28]$} \\
\hline Tuberaphis leeuweni & $500 \sim 1,300(n=5)$ & $21 \sim 52 \%$ & {$[40]$} \\
\hline
\end{tabular}

${ }^{1}$ Colony sizes of mature galls (containing alates and/or fourth-instar wingpadded nymphs). Undeveloped or damaged galls (due to predation or for an unknown reason) are omitted from the data.

as a defensive behavior against mammals [2, 101]. Perhaps soldiers that can cause troublesome irritation in humans, including those that do not readily fall off the gall, may repel some vertebrate predators.

In Tuberaphis styraci, one of the main ingredients of the venom injected into natural enemies by the soldiers was identified by Kutsukake et al. [154] as a cysteine protease of the family cathepsin B. The gene encoding this protease (called "S-type cathepsin B gene") expresses specifically in the soldier morph and leads to the production of the protease in the intestine [155]. In other Tuberaphis species (T. coreana, T. taiwana, T. sumatrana, and T. takenouchii), too, the same S-type gene specifically and strongly expresses in the soldier morph. However, in Astegopteryx styracophila, A. spinocephala, and Cerataphis jamuritsu, the S-type gene rather weakly and non-specifically expresses in the soldier morph. Although the S-type gene of $C$. jamuritsu is still transcribed, it contains a stop codon and is likely to be a pseudogene [155]. In these non-Tuberaphis cerataphidines, therefore, the main ingredient of the venom is something other than the cathepsin B protease.

In species whose colonies become large (e.g., Ceratoglyphina styracicola [102], Pseudoregma sundanica [29], Tuberaphis owadai [11]), many soldiers reside on the outer surface of their gall (Figure 12(b)). In others (e.g., Cerataphis brasiliensis, Astegopteryx styracophila), all inhabitants including soldiers reside within the gall or subgalls, and a number of soldiers guard at the small ostiole(s) and face outward from the inside of the (sub)gall [19, 88, 130]. Among them, soldiers of Astegopteryx spinocephala cooperate to plug the ostiole with their sclerotized spiny heads from inside [132]. When their gall is disturbed, soldiers rush out of the (sub)gall and excitedly walk around on the outer surface.
These soldiers soon begin to retreat into the (sub)gall if they encounter no enemies [19, 132].

Soldiers may emit an alarm pheromone from their cornicles. When their gall is disturbed, soldiers of Ceratoglyphina styracicola excitedly walk around on the outer surface of the gall while raising the tip of the abdomen upward [101, 108], perhaps emitting an alarm pheromone. Shibao et al. [156] mention that soldiers of Tuberaphis styraci discharge, from their cornicles, yellowish droplets containing $(E)-\beta$ farnesene, which is used as an alarm pheromone in many aphid species [157, 158].

5.3.3. Predators of Gall-Living Generations. Here we briefly review predators of gall-living cerataphidines. Larvae of the pyralid genus Assara (Lepidoptera) are one of the commonest predators. The larvae bore into cerataphidine galls. Within the gall they live in a silken net and thereby escape attack from soldiers and prey on aphids by protruding the head from the net. Three species have hitherto been identified: Assara formosana from galls of several cerataphidine species in Taiwan [107] and Thailand [17], A. holophragma from galls of Astegopteryx styracophila in Sumatra [19], and Assara seminivalis from galls of Tuberaphis owadai in northern Vietnam [11]. The reason why soldiers of some species reside on the outer surface of their gall (Section 5.3.2) is probably that they defend the gall against such lepidopteran larvae. Larvae of the polyphagous vine moth Eupoecilia ambiguella (Tortricidae) often bore into subgalls of Ceratovacuna nekoashi one after another and eat both the inner walls and the aphids [138]. Other Styraxfeeding moth larvae are also likely to be potential enemies of cerataphidine galls. 
Larvae, pupae, and adults of the coccinellid genus Sasajiscymnus (formerly known as "Pseudoscymnus," which turned out to be a junior homonym of a fish genus name [159]) are found from within some cerataphidine galls: $S$. sylvaticus from subgalls of Ceratovacuna nekoashi $[160,161]$ and C. japonica [20], and S. sp. from those of Astegopteryx spinocephala [17]. Unidentified larvae of other coccinellid groups have also been found from galls of Cerataphis vandermeermohri [9, 10] and subgalls of Astegopteryx pallida [19]. Predaceous beetle larvae (sometimes together with adults) of Mimemodes sp. (Rizophagidae, Monotominae) have been found from galls of Cerataphis brasiliensis [34] and subgalls of Astegopteryx styracophila [19], and those of Aethina sp. (Nitidulidae, Nitidulinae) from galls of Tuberaphis taiwana [38] and subgalls of Pseudoregma bambucicola [26].

Syrphid larvae are one of the commonest predators of aphids in general, and some (e.g., Heringia senilis, Pipiza spp.) are specialist predators of aphids within galls [162]. However, syrphid larvae have rarely been found in cerataphidine galls. Up to now we have found only one cerataphidine gall (of Tuberaphis sumatrana on Styrax subpaniculatus in Sumatra) containing several larvae of a syrphid species (our unpublished observation). For an unknown reason, no parasitoid wasps are known from gall-living cerataphidines.

As mentioned in the previous section, vertebrates such as mammals may be potential predators of cerataphidine galls. However, it is difficult to observe an incident of predation directly. Chou et al. [163] observed that the squirrel Callosciurus erythraeus ate a total of four galls of Astegopteryx bambucifoliae (reported as "Eulachnus" sp.; see [101]) on Styrax suberifolius in Taipei, Taiwan. So far, this is the only direct observation on predation of cerataphidine galls by vertebrates. Outside the Cerataphidini, Japanese monkeys (Macaca fuscata yakui) are known to break hard, lignified galls of Nipponaphis monzeni (Hormaphidinae, Nipponaphidini) with their teeth and eat the aphids inside [164]. Sunose [165] observed that galls of Paracolopha morrisoni (Eriosomatinae, Eriosomatini) were pecked by tree-sparrows (Passer montanus) and the aphids were consumed. Great tits (Parus major) exploit galls of Paracletus cimiciformis and Forda formicaria (Eriosomatinae, Fordini) as a source of food [166].

5.3.4. Defense against Aphids of the Same or Different Species. Gall-living aphids send off some of their clonemates, usually nymphs, into other conspecific galls. These intruders exploit resources of foreign galls rather than of their natal gall, thus indirectly helping their clonemates remaining in the natal gall $[5,167]$. This phenomenon, called "intergall migration," is known in non-cerataphidine species including Pachypappa marsupialis [168], Pemphigus spp. [169-171], and Adelges japonicus [172]. Such migration of nymphs between conspecific galls is likely to occur also in cerataphidine species, because it is known that some cerataphidines, Ceratoglyphina styracicola [103], Astegopteryx bambucifoliae [26, 88], Pseudoregma bambucicola [88], and Cerataphis brasiliensis [5] intrude into galls of different species on the same host tree. In fact, soldiers of some species attack aphids of the same or different species. Soldiers of C. styracicola, on the outer surface of their gall, attack conspecific aphids except conspecific soldiers, whether they are clonemates or not, in at least some seasons $[102,106]$. This strongly suggests that soldiers cannot discriminate between kin and non-kin (or between clonemates and non-clonemates), that they do discriminate between soldiers and non-soldiers, and that their galls are under threat from invasion and exploitation by nearby conspecific colonies [5]. Soldiers of P. bambucicola and A. bambucifoliae also attack aphids of the same or other species at the ostiole and prevent at least some of them from intruding into the subgall [88].

5.3.5. Cleaning Behavior. The second-instar soldiers push globules of honeydew, cast-off skins, and dead aphids out of the (sub)gall with their heads [28, 39, 131, 132, 145]. Usually there remain few cast-off skins and few dead aphids in healthy cerataphidine galls. A possible exception may be Ceratovacuna nekoashi, whose soldiers do not actively push garbage out of their subgall. As mentioned in Section 5.3.1, soldiers have one or a few pairs of spine-like setae on the frons, which probably function as a brush for gall cleaning [39].

Age polyethism may occur in some species. Young soldiers of Tuberaphis styraci preferentially perform gall cleaning tasks, whereas aged soldiers exclusively exhibit attacking behavior [173]. In this connection, it will be interesting to know whether those soldiers of Ceratoglyphina styracicola that fall off their gall (Section 5.3.2) are aged ones or not.

Gall cleaning behavior has been found also in aphids belonging to other taxa, including the hormaphidines Hormaphis betulae and Hamamelistes miyabei $[174,175]$, and the pemphigines Pemphigus dorocola [176] and P. spyrothecae [177].

5.3.6. Ants and Aphid Soldiers on the Primary Host. No intimate symbiosis has been recorded between gall-living cerataphidines and ants. Usually ants are not seen on cerataphidine galls (e.g., [34]), but sometimes ants collect honeydew directly from openings of a gall $[28,145]$ (Figure 4(a)). Kurosu et al. [145] observed that a soldier of Ceratovacuna japonica grasped a gall-attending ant of Pristomyrmex pungens, and that some ants crushed aphid soldiers with their mandibles on the same gall. Although not yet confirmed, gall-attending ants may widen openings of the gall, which may have a negative effect on the aphid colony.

5.3.7. Percentage of Soldiers in Galls. The number and percentage of soldiers vary between gall stages and between species. In some species that form large galls (e.g., Ceratoglyphina styracicola, Tuberaphis owadai), a single colony may produce several tens of thousands of soldiers (Table 3). In those species that form small galls (e.g., Pseudoregma carolinensis), a single colony may contain only hundreds of soldiers. The percentage of soldiers at times reaches $40-60 \%$ when the gall matures (Table 3 ). 
5.3.8. Sterility of Soldiers in Galls. Cerataphidine soldiers produced in Styrax galls are sterile and do not molt past the second instar. To confirm this, we have examined, for each species, approximately one hundred slide-mounted specimens of soldiers under a light microscope to determine whether they have the next (third) instar cuticle developing inside. A sample of non-soldier nymphs (i.e., reproductivesto-be) is likely to include some individuals with the next instar cuticle. For instance, of 94 first-instar non-soldiers of Pemphigus spyrothecae (Eriosomatinae, Pemphigini) we examined, 18 (19.1\%) had the next instar cuticle developing inside [178]. If no individuals with such a cuticle are found among about one hundred soldiers of a species, it will be reasonable to conclude that soldiers of the species are sterile. Of course, if the molting rate is much smaller, say one percent, the examination of one hundred individuals will be insufficient (the probability of finding no such individual will be near $\mathrm{e}^{-1}$, or 0.37 ). In Table 4 , the results for 19 species are summarized. The data support the soldiers' sterility in general, but there have been reported two exceptional cases in which some soldiers may molt. (1) In a mature gall of Astegopteryx bambucifoliae with 750 aphids, four out of 476 soldiers had the next instar cuticle developing inside [16]. (2) In a very young gall of Ceratoglyphina styracicola with 13 live aphids, five out of six soldiers had the next instar cuticle [105]. No such soldiers were found in other galls of either species. Because soldiers are likely to be accepted by guarding soldiers of other conspecific galls $[88,106]$, and because soldiers are shown to intrude into galls of other species [26, 88 ], we suggest that the molting soldiers mentioned above were intruders from other galls. This possibility requires confirmation.

In Tuberaphis styraci, soldiers survive over 20 days (after the first molt) on an artificial diet, while the second stadium of normal nymphs is around 10 days [173].

5.3.9. Proximate Factors for Soldier Production. Proximate factors for the production of soldiers have been studied with Tuberaphis styraci, because the species is one of few social aphids that can be maintained on an artificial diet for over two months [179]. Shibao et al. [180] showed that high aphid density induces soldier production. When mother apterae and/or their first-instar nymphs are reared under crowded conditions, more soldiers (which are second instar) are produced. The combination of prenatal high density and postnatal high density enhances soldier differentiation in a synergistic manner [181]. Direct contact with other aphids is a cue for soldier induction [182]. Soldier production is enhanced by coexisting non-soldiers, but suppressed by coexisting soldiers [183]. Thus, the percentage of soldiers in $T$. styraci is controlled by positive and negative feedbacks consisting of density-dependent induction and suppression of soldier differentiation $[183,184]$.

5.4. Exules. "Exules" are the aphids that are produced on the secondary host but usually do not include sexuparae. Colonies on the secondary host are founded by alates (emigrants) coming from the primary host, or by alates (secondary migrants) or first-instar nymphs from other secondary hostplants. First-instar exules are active walkers and often dispersed on the wind $[84,93,185,186]$. Except for Tuberaphis takenouchii [37], T. macrosoleni, and T. cerina [42], which form and live in leaf galls or rolled leaves, most cerataphidines form an exposed colony that sprawls over a plant or a clump of plants. The demarcation of such a colony is sometimes not clear. Colonies of Pseudoregma alexanderi and $P$. baenzigeri that are formed on such tall bamboos as Dendrocalamus spp. often become huge $[118,185]$ and the number of aphids may exceed one million [118]. Many species such as Pseudoregma species form dense colonies (Figure 4(b)) on their host plants. Species of the genus Astegopteryx (except A. basalis [42]), on the other hand, form "spaced-out" colonies (Figure 3(b)) on leaves of the host plants; that is, aphids as a whole are aggregated to form a colony, but individual aphids are more or less spaced out from each other $[87,187]$.

Because more than one alate may come to a single leaf [86] or a single plant, and because alates or wind-dispersing nymphs may join already established colonies [27], colonies on the secondary host are not always pure clones [185].

The morphology of exules (nymphs and apterous adults) is rather uniform among genera (Astegopteryx, Ceratovacuna, Pseudoregma, Ceratoglyphina, and Chaitoregma) that form (or are supposed to form) multiple-cavity galls on the primary host. They all have a pair of frontal horns with minute setae. On the other hand, the morphology of exules differs fairly among genera (Cerataphis, Tuberaphis, and Glyphinaphis) that form (or are supposed to form) singlecavity galls. Exules of Glyphinaphis have no frontal horns, while those of Cerataphis, as its name suggests, have a pair of frontal horns which bear no setae. (The frontal horns of Cerataphis therefore might not be homologous with those of Pseudoregma and its four allied genera.) Exules of Tuberaphis do or do not have horn-like projections [42, 49].

5.4.1. Butting Behavior. Exules of many cerataphidines use their pair of frontal horns to butt conspecific aphids, or colony-mates, to gain occupation of a good feeding site on the host plant. In this interaction, a non-feeding aphid walks over to a feeding aphid, fixes all its legs on the plant, and repeatedly thrusts its body forward; the horns usually hit the aphid body being attacked. All instars but alates show this behavior. Though not frequently, soldiers (see Section 5.4.2) do, too [185]. Large instars (apterous adults or wingpadded fourth-instar nymphs) more frequently defeat small instars (early-instar nymphs) than vice versa. Note that this butting behavior is different from attacking behavior against a predator or an enemy; in the latter, the attacker clasps the predator with its forelegs or all legs, while in the former the attacker butts a conspecific aphid while keeping all its legs on the plant. The butted aphid shows some defensive behavior, which varies between species.

In Pseudoregma alexanderi and Ceratovacuna nekoashi, which form compact colonies on the host plant (Figure 2(b)), an attacked aphid raises its abdomen when butted from behind. The attacker aphid then creeps under 
TABLE 4: Molting rate of cerataphidine soldiers in Styrax galls.

\begin{tabular}{lccc}
\hline Species & No. of soldiers examined & No. (\%) of molting soldiers & References \\
\hline Astegopteryx bambucifoliae & 821 & $4(0.5 \%)$ & {$[16]$} \\
Astegopteryx styracophila & 109 & 0 & {$[19]$} \\
Astegopteryx pallida & 100 & 0 & {$[19]$} \\
Astegopteryx spinocephala & 100 & 0 & {$[17]$} \\
Ceratovacuna japonica & 215 & 0 & {$[20]$} \\
Pseudoregma bambucicola & 268 & 0 & {$[26]$} \\
ditto (young gall) & 94 & 0 & {$[100]$} \\
Pseudoregma koshunensis & 133 & 0 & {$[153]$} \\
Pseudoregma sundanica & 100 & 0 & {$[29]$} \\
Pseudoregma carolinensis & 100 & 0 & {$[28]$} \\
Ceratoglyphina styracicola & 126 & 0 & {$[2]$} \\
ditto & 530 & 0 & {$[103]$} \\
ditto (young gall) & 63 & 0 & {$[104]$} \\
ditto (young gall) & 37 & $0(13.5 \%)$ & {$[105]$} \\
Tuberaphis styraci & 139 & 0 & {$[39]$} \\
Tuberaphis taiwana & 250 & 0 & {$[38]$} \\
Tuberaphis leeuweni & 121 & 0 & {$[40]$} \\
Tuberaphis takenouchii & 8 & 0 & {$[36]$} \\
Tuberaphis owadai & 238 & 0 & {$[11]$} \\
Cerataphis brasiliensis & 100 & 0 & {$[34]$} \\
ditto (young gall) & 200 & 0 & {$[34]$} \\
Cerataphis jamuritsu & 130 & 0 & {$[35]$} \\
Cerataphis vandermeermohri & 118 & 0 & {$[10]$} \\
Cerataphis bambusifoliae & 127 & & {$[33]$} \\
\hline & & 0 &
\end{tabular}

the abdomen and begins feeding there. This leads to the formation of a compact colony. The attacker, however, sometimes does not cease butting after creeping under the abdomen. In this case, especially when the aphid being butted is solitary, the aphid is forced to withdraw its stylets from the plant tissue and driven away $[4,185]$.

In Astegopteryx bambucifoliae and A. minuta, which form sparse colonies on bamboo leaves, the reaction of a butted aphid is more elaborate. When butted from other than the front, the butted aphid turns itself to face toward the attacker, without withdrawing its stylets from the plant, and raises its abdomen and lowers its head to shield itself against the butt. The attacker may escalate the fight: it clasps the opponent's body with its forelegs (see a dueling pair in the lower right corner of Figure 3(b)) and repeatedly thrusts its body back and forth. In this attack, the attacker's horns no longer hit the opponent's body. The aphid being attacked then raises its abdomen further, to such an extent that its hind legs are detached from the plant and that its abdomen is bent forward to lean on the attacker, performing a headstand [187]. The attacker may or may not force the opponent away. When the attacker succeeds in forcing the aphid away, it begins feeding at the spot where the attacked aphid was feeding [188]. Hence this fighting is for a good feeding spot. By applying electrical penetration graph techniques to Astegopteryx pallida, which forms similar sparse colonies on bamboo leaves, Morris and Foster [189] showed that horned aphids use the exact feeding site vacated by another individual and that the benefit they gain is rapid access to the phloem.

Apterous adults of the palm aphid Cerataphis brasiliensis are armored well. The head with two sharp horns and the three thoracic tergites are united to form one large sclerotic plate, and the first to seventh abdominal tergites are also united to form another large sclerite. At the butting, an attacker bends its body like a roof and snaps its anterior sclerite upward to move off a feeding aphid. In this species, the attacked aphid often counterbutts the attacker aphid. Howard at al. [190] describe the fight as follows.

"To butt another aphid, an aphid lowers its head, places its horns beneath the head of the other aphid, then snaps its head upward while simultaneously thrusting forward with the legs. The motion often lifts the other aphid at its margin. Each of the dueling pair responds to being butted within a few seconds by butting its opponent. The altercation may last up to 19 minutes, the aphids often exchanging blows about 40 times per minute and alternately resting for intervals of several minutes."

Although Howard et al. [190] mention that "neither one (of the dueling pair) seemed to be injured by the other," we [4] once observed under a dissecting microscope in a room that an apterous adult was snapped by another and turned upside down (at Iriomote, southern Japan, between 14 and 
16 March 1986). Because these aphids were on the underside of a palm leaflet, the snapped aphid would have fallen off the leaf under natural conditions. Such an apparent cost of the duel suggests that the opponent is a non-clonemate at some probability.

In all horned cerataphidines investigated so far, butting behavior was observed ([4] and our later unpublished observations). In some species such as Chaitoregma tattakana and Tuberaphis coreana, however, the behavior is sluggish and difficult to interpret.

5.4.2. Soldiers on the Secondary Host. All but one species of the genus Pseudoregma [118] and several species of Ceratovacuna $[42,83,84,86,185]$ produce sterile first-instar soldiers on the secondary host. The soldiers are larger than the "normal" first-instar nymphs, their forelegs are greatly thickened, and their horns are long and sharp [3, 191, 192]. They clasp such a predator as a syrphid larva with the thickened forelegs and pierce it with the sharp frontal horns (not with their stylets) [185]. Although frontal horns of cerataphidines evolved originally for intracolonial butting (Section 5.4.1), they were later converted into a piercing weapon in Pseudoregma and Ceratovacuna [4, 185]. An attacking soldier repeatedly thrusts its body forward until the horns are embedded deep into the predator's body, which may rapidly exhaust the energy reserves of the soldier and lead to its death in a few hours [193]. The soldiers also crush eggs of predators with the horns [91] and at times pierce aphids of other species on the same host plant [185]. A soldier may also clasp a conspecific aphid. In such a case, however, the attack is not escalated, and the soldier soon detaches itself from the aphid, without injuring it [185]. Schütze and Maschwitz [194] suggest haemolymph from the predator, its prey aphid, or other insects as a cue that escalates the soldier's attacking behavior in Pseudoregma sundanica. It is unknown what is the first cue that causes a soldier to clasp a predator. Unlike soldiers on the primary host (Section 5.3.1) and first-instar defensive nymphs of Ceratovacuna lanigera (Section 5.4.6), soldiers of all species of Pseudoregma and most species of Ceratovacuna produced on the secondary host lack cornicles and therefore do not discharge droplets of cornicle secretion. Second and later instar nymphs and adults have a pair of ring-like cornicles and discharge dark, sticky cornicle secretion when attacked by a predator. It is unknown whether an alarm pheromone is involved in the defensive system. The dark secretion is often attached to the predator's body (see photos in [195]); it may have some defensive effect, as is reported in the nipponaphidine Quadrartus yoshinomiyai $[196,197]$. Like soldiers on the primary host, soldiers produced on the secondary host cannot discriminate between kin and non-kin, or between colonymates and noncolonymates $[84,93,186]$.

Soldiers on the secondary host are completely sterile. No soldiers with the next instar cuticle developing inside have been found (Table 5). Sakata and Itô [93] reared soldiers of Pseudoregma bambucicola in cages on bamboo leaves or shoots in the laboratory and found that they survived for 55 days on average, 116 days at longest $(n=6)$. Soldiers ingest
TABLE 5: Molting rate of cerataphidine soldiers on the secondary host.

\begin{tabular}{lccc}
\hline Species & $\begin{array}{c}\text { No. of } \\
\text { soldiers } \\
\text { examined }\end{array}$ & $\begin{array}{c}\text { No. of } \\
\text { molting } \\
\text { soldiers }\end{array}$ & References \\
\hline Pseudoregma alexanderi & 123 & 0 & {$[3]$} \\
Pseudoregma bambucicola & 233 & 0 & {$[185]$} \\
Pseudoregma panicola & 13 & 0 & {$[185]$} \\
Pseudoregma carolinensis & 35 & 0 & {$[117]$} \\
Pseudoregma baenzigeri & 77 & 0 & {$[118]$} \\
Ceratovacuna japonica & 100 & 0 & {$[185]$} \\
Ceratovacuna cerbera & 78 & 0 & {$[86]$} \\
\hline
\end{tabular}

plant sap and excrete honeydew [198] but less frequently than normal first-instar nymphs do [199]. The sugar content in a droplet of honeydew, on average, is $2.9 \mu \mathrm{g}$ for the soldier and $7.6 \mu \mathrm{g}$ for the normal first-instar nymph in $P$. koshunensis, and the amino acid composition in honeydew is also different between the two morphs [199]. These suggest a difference in nutritional requirements between them.

Soldiers and normal first-instar nymphs are differentiated already in the embryonic stage [192]. A small number of intermediate individuals between the two morphs may appear [192]. The normal first-instar nymphs also have sharp frontal horns. In at least some species, they join attack on predators and/or competitors [86, 185, 200].

Soldiers are variable in size within a single species. The armatures of soldiers of Ceratovacuna japonica vary in size and shape between seasons and populations [83]. In Pseudoregma alexanderi, soldiers in a single colony at times fall into two size groups, "majors" and "minors" $[3,191]$. It is unknown whether soldiers of these two size groups play different roles.

So far as is known, these horned soldiers occur in only two closely related genera, Pseudoregma and Ceratovacuna, while all cerataphidine species produce soldiers on the primary host. This fact indicates that the evolution of soldiers on the primary host preceded the evolution of soldiers on the secondary host.

5.4.3. Percentage of Soldiers on the Secondary Host. Percentage of soldiers on the secondary host has been intensively studied for Pseudoregma bambucicola on Bambusa multiplex by a number of researchers in Kagoshima, southern Japan [90, 94, 95, 97]. Itô et al. [95] and Shibao [97], in particular, counted the number of soldiers for many colonies of $P$. bambucicola. The proportion of soldiers varies considerably across seasons (from zero to ca. 40\% [90, 95]) and colonies (from zero to $35 \%$ [97]). The consensus of the researchers is that many soldiers are produced in large colonies, and few or no soldiers in small colonies [95, 97], although the correlation is not strong (Figure 13). The same tendency was also detected in Pseudoregma sundanica on ginger [194, 200] and perhaps holds true for soldier-producing aphids in general. The tendency can be explained if we assume logistic growth of the aphid colony and the optimal proportion 


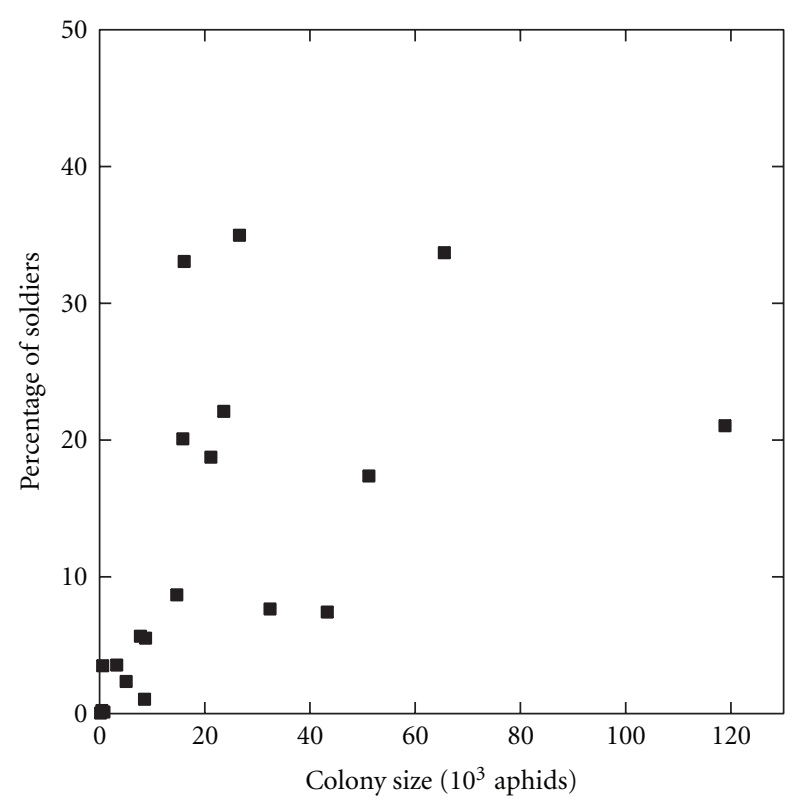

FIGURE 13: Relationship between colony size and the percentage of soldiers in Pseudoregma bambucicola on Bambusa multiplex. Data for 20 colonies sampled in Kagoshima and Miyazaki Prefectures, Japan, from October to December are shown (drawn from data in [97]). The correlation coefficient is 0.63 after arcsin square-root transformation of the percentage values.

of soldiers that maximizes the total productivity. Aoki and Kurosu [201] showed that a soldier of any given ordinal number (e.g., a first soldier, or a twelfth soldier) can be more readily produced in a large colony than in a small colony. This is because (1) a soldier benefits all non-soldiers in the colony by killing or repelling predators, and because (2) the value of a non-soldier (i.e., a reproductive) decreases as the colony size increases. Under these and some auxiliary assumptions, Aoki and Imai [202] carried out simulations, which indicated that the proportion of soldiers increases as the colony size increases. Although our model [202, 203] does not take into account the replacing cost of soldiers (i.e., assuming immortal soldiers), it indicates how effective a soldier must be if it is produced: a soldier must increase each non-soldier's productivity by larger than $r_{\mathrm{m}} / K$. In other words, the marginal defensive efficacy of a soldier must be larger than $r_{\mathrm{m}} / K$, where $r_{\mathrm{m}}$ and $K$ are the maximum intrinsic rate of increase and the carrying capacity of the aphid colony without soldier, respectively. The ratio appeals to our intuition because $r_{\mathrm{m}}$ and $K$ are well-known parameters in the logistic equation.

5.4.4. Leg-Waving Behavior. Many apterous adults and nymphs (including soldiers) of some Pseudoregma species in a colony, when they are disturbed (e.g., when the host plant is lightly touched), respond by waving their legs all together. This leg-waving (or leg-shaking) behavior is noticeable in P. bambucicola $[93,99,111,204]$ and P. alexanderi [185], which form colonies on bamboo shoots or twigs. Individual aphids lift their hind legs (and at times their abdomens, too) and move them up and down, their fore and mid legs remaining in situ $[93,185]$. Synchronized with this behavior, many droplets of honeydew fall from the colony [185]. According to Sakata and Itô [93], soldiers of P. bambucicola lift both their abdomens and hind legs more frequently than normal first-instar nymphs do. Shingleton and Foster [205] succeeded in inducing many soldiers but only a few nonsoldiers of Pseudoregma sundanica (on ginger) to shake their legs by blowing gently on them. Stern et al. [206] observed leg waving of many aphids when predatory wasps passed near and walked over the surface of a colony of Pseudoregma sp. on bamboo. Ôhara [91] observed that a gravid female of the hoverfly Eupeodes confrater, which is a specialist predator of Pseudoregma bambucicola on bamboo and often lays her eggs on spider threads (Section 5.4.5), induced leg-waving behavior.

" [A gravid] female [of E. confrater] approached [a] bamboo [shoot infested with P. bambucicola] in a straight line. She then hovered at various heights, and moved around the bamboo at a distance of a few centimeters. She examined the aphids at an angle of 45-60 degrees as she repeatedly flexed and contracted her legs. Both the soldiers and other morphs of P. bambucicola in the colony reacted to the fly's proximity by lifting and shaking their hind legs."

Kenji Ôhara (personal communication) once suggested to us that, by so doing, the female of $E$. confrater might assess defensive activity of the aphid colony and, based on this information, decide where to lay her eggs, that is, whether she should oviposit directly onto the colony or on nearby spider threads so that soldiers could not readily kill her eggs.

While leg-waving is regarded as a defensive behavior $[6,96,200,207]$, how it works is still utterly unknown. Schütze and Maschwitz [207] mention that the behavior "must be understood as an unspecific defensive behavior." Other researchers have suggested that it may deter syrphids from ovipositing $[96,99]$ or ward off flying parasitoids $[99,200]$. In this connection it may be worth pointing out that few parasitoid wasps have been recorded from cerataphidines; the aphelinid Encarsia flavoscutellum from Ceratovacuna lanigera and Astegopteryx nipae [208] and E. ceratiphivora from Cerataphis brasiliensis [209] are rare exceptions. We add another yet-untested hypothesis that the simultaneous leg-waving seen in Pseudoregma species might be a kind of bluff that is effective against larger predators, possibly against birds.

Outside the Cerataphidini, leg-waving behavior is known in some species of Aphidinae and Lachninae [204, 210].

5.4.5. Predators of Soldier-Producing Species. Because soldiers on the secondary host can kill usual predators of aphids, predators often observed in their colonies are those that have developed some devices for escaping attack by the soldiers. The large coccinellid Synonycha grandis, the small coccinellid Sasajiscymnus amplus, the syrphid Eupeodes confrater, and the pyralid Dipha aphidivora are specialist predators of 
the soldier-producing species Pseudoregma alexanderi, $P$. bambucicola, and P. koshunensis in southern Japan and/or Taiwan $[185,195,211]$.

Larvae and adults of $S$. grandis prey on aphids in and on the outskirts of the aphid colony. Both are well armored with hard skins and soldiers are unlikely to pierce them with the horns; soldiers of P. bambucicola clasp or push the legs of the larvae and force them to fall off the bamboo [97]. Larvae of Sasajiscymnus amplus (see [212]), on the other hand, prey on aphids in the colony without being attacked by soldiers [185]. The larvae so much resemble prey aphids, those of P. alexanderi in particular (see a photograph on page 421 of Moffett [195]), that an observer frequently loses sight of them once he takes his eyes off the aphid colony. The reason for the close resemblance is yet unknown. Larvae of an unidentified species of Scymnini, whose bodies are slender in shape and which therefore do not resemble the prey aphids, have been obtained from colonies of Pseudoregma baenzigeri (our finding unreported in [118]).

Larvae of Dipha aphidivora weave silk tunnel nests within the aphid colony on the culm of bamboo and put their heads out of the tunnel to catch aphids, usually without being attacked by soldiers [195, 211, 213]. Early-instar larvae of Taraka hamada (Lycaenidae) and larvae of Atkinsonia ignipicta (= "Oedematopoda semirubra") (Stathmopodidae) also live in such silken nests and prey on aphids of Pseudoregma [211], but their main prey in Japan is Ceratovacuna japonica [214-217].

The syrphid Eupeodes confrater is famous for its acrobatic ovipositing behavior. Gravid females frequently lay their eggs onto fine threads of spiders' webs near the aphid colony $[91,96,195,211]$. Soldiers of Pseudoregma, with their horns, easily crush eggs of $E$. confrater laid directly onto bamboo culms $[91,92,97]$. The oviposition on the threads is therefore an adaptation for avoiding attack by aphid soldiers. According to Ôhara [92], a single soldier of P. bambucicola can lift up a just-hatched larva of E. confrater and may fall off the colony together with the larva, but it can no longer lift up a first-instar larva after the larva has consumed an adult aphid and become heavier. Ôhara [92] has repeatedly observed that, when a soldier clasps the posterior part of the syrphid body, the soldier dies and is detached from it in a few minutes, without being counterattacked by the syrphid with its mouthhook. He suggests that the first-instar syrphid larva may secret a chemical substance which is toxic to the aphid soldier. This interesting possibility has not yet been confirmed by later researchers. Shibao [97] experimentally showed that defense by soldiers of $P$. bambucicola is effective, to at least some degree, against the specialist predator E. confrater (as well as against the coccinellid S. grandis).

Colonies of Pseudoregma also attract generalist predators and the soldiers repel them $[4,185]$. The syrphid Episyrphus balteatus and the hemerobiid Micromus numerosus recorded by Morimoto and Shibao [211] are likely to be such generalist predators. Both are known to prey on various species of aphids $[219,220]$.

Rodents sometimes eat aphids of Pseudoregma on bamboo [118].
5.4.6. Defense by Monomorphic Nymphs: Piercing with Horns. Some cerataphidine species have monomorphic first instars and do not produce morphologically distinct sterile soldiers; nevertheless these "monomorphic" first-instar nymphs have sharp horns and attack predators with the horns. Examples are an unnamed species of Pseudoregma found on Schizostachyum zollingeri in the Malay Peninsula [206] and the sugarcane woolly aphid, Ceratovacuna lanigera; the defensive behavior of the latter is well studied and treated here.

First-instar nymphs of Ceratovacuna lanigera are monomorphic and active walkers, and, when eggs of syrphids or hemerobiids are laid in or near the colony, they damage and crush the eggs with their sharp frontal horns $[116,218$, 221]. Eggs of non-specialist predators such as the syrphids Episyrphus balteatus, Ischidon scutellaris, and Syrphus ribesii, and those of the hemerobiid Eumicromus navigatorum are quite easily crushed by the nymphs [116, 218, 222]. Some predators have evolved a counteradaptation to the attack by the nymphs. Adult hoverflies of Eupeodes kuroiwae (referred to as "Metasyrphus hakiensis" in [218]) closely resemble those of E. confrater, a predator of Pseudoregma species (see Section 5.4.5), and the species has been recorded under the latter's name as a predator of C. lanigera ([223225], see [116]). Eggs of the two species are, however, very different from each other. As mentioned before, egg shells of E. confrater are not very hard, and soldiers of Pseudoregma bambucicola easily pierce and kill them. Eggs of E. kuroiwae are, on the other hand, slender, cylindrical in shape, and the eggshell is so hard that first-instar nymphs of C. lanigera cannot pierce it with their horns. Gravid females of E. kuroiwae lay their eggs close to colonies of C. lanigera, so that aphid nymphs attack almost all laid eggs (Figure 14(a)) but fail to kill them [116, 218]. Eggs of Dideoides latus, another syrphid predator specialized for $C$. lanigera (and perhaps also for other Ceratovacuna species with soldiers), are not so tough as those of E. kuroiwae but much tougher than those of the generalist syrphid predators mentioned above. First-instar aphid nymphs may kill eggs of $D$. latus, but only after their persistent attacks, often over a few days. To avoid attacks by soldiers, females of $D$. latus lay their eggs apart from aphid colonies, at times more than $1 \mathrm{~m}$ away from the nearest colony [218] (Figure 14(b)).

Attacking first-instar nymphs often discharge, from one cornicle or both on their posterior abdominal tergites, a droplet which contains an alarm pheromone and recruits other first-instar nymphs [222]. Unlike soldiers of Tuberaphis styraci (on the primary host), aphids of $C$. lanigera do not react to (E)- $\beta$-farnesene [116]. Because the greenbug, Schizaphis graminum (Aphidinae), which uses $(E)$ - $\beta$-farnesene as an alarm pheromone [157], exhibits no response to the cornicle secretion of $C$. lanigera, $C$. lanigera is likely to use another unidentified chemical as the alarm pheromone [116].

First-instar nymphs of Ceratovacuna lanigera also attack larvae of predators. Arakaki [116] showed that their attack is effective against larvae of a generalist predator, Episyrphus balteatus. 


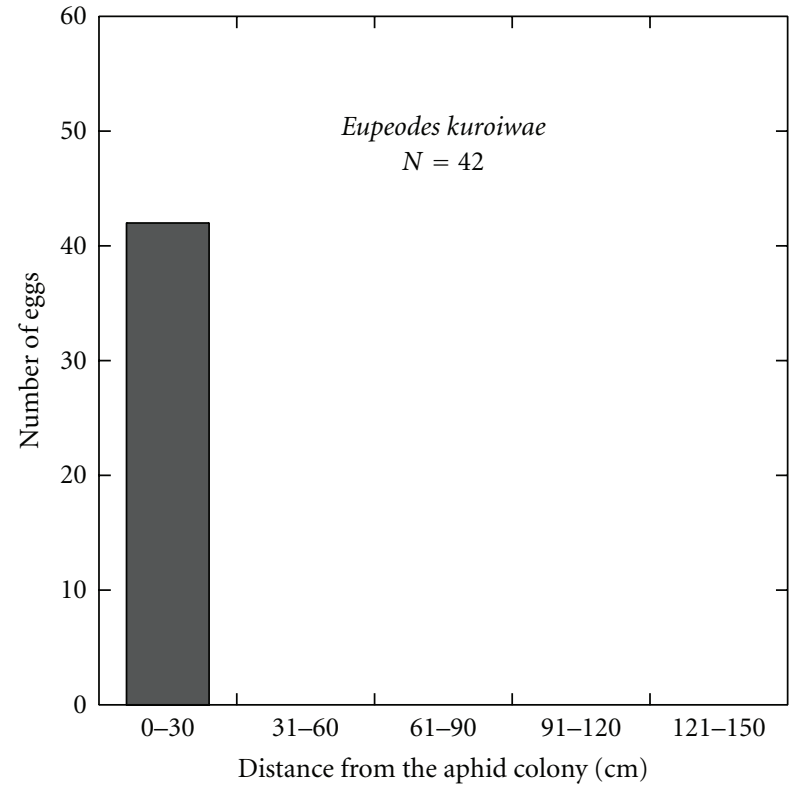

(a)

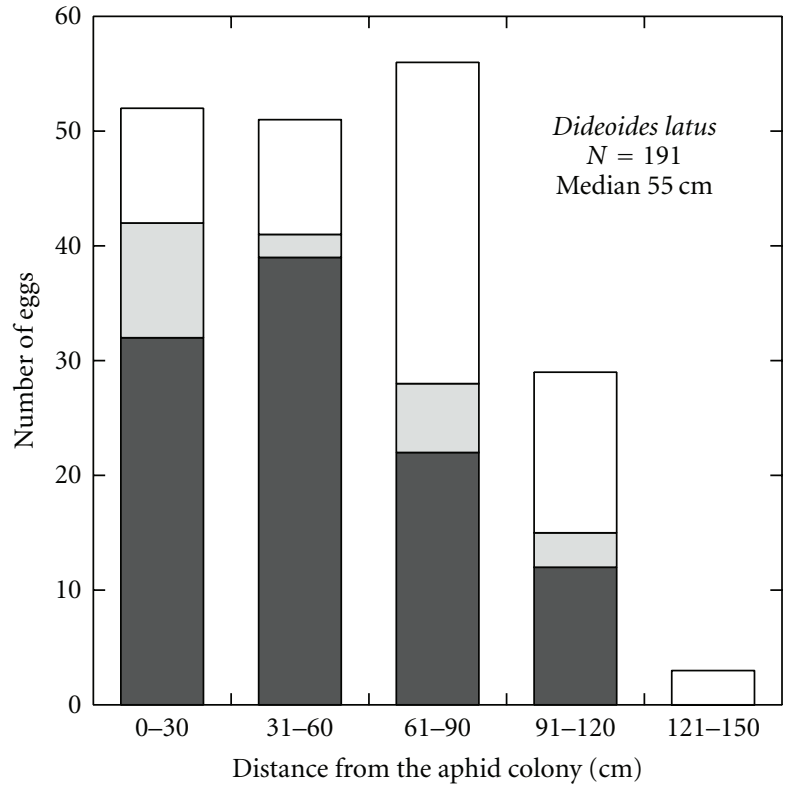

(b)

FIGURE 14: Distribution of eggs laid by two syrphid species in and around a colony of the aphid Ceratovacuna lanigera formed on the grass Miscanthus sinensis. Eggs that were and were not attacked by aphid nymphs within first three days are indicated by dark grey and white areas, respectively, and those that disappeared within first three days by light grey areas. (a) Eupeodes kuroiwae. Although all laid eggs were attacked, the hatchability of attacked eggs in E. kuroiwae (71.9\%) was much higher than that in Dideoides latus (29.8\%) ( $2 \times 2$ Fisher's exact test; $P \ll .0001$ ). (b) Dideoides latus. Eggs of $D$. latus that were laid more than $55 \mathrm{~cm}$ (the median) away from the colony were less likely to be attacked by aphid nymphs than those that were less than $55 \mathrm{~cm}$ away $(2 \times 2$ Fisher's exact test; $P=.0001)$. Also, the hatchability of attacked eggs $(29.8 \%)$ was lower than that of unattacked eggs $(70.1 \%)(2 \times 2$ Fisher's exact test; $P \ll .0001)$ (redrawn and recalculated from data in [218]).

5.4.7. Defense by Monomorphic Nymphs: Piercing with Stylets. Tuberaphis takenouchii produces exules with no horns in its leaf roll galls formed on mistletoes of the family Loranthaceae. First-instar nymphs of the secondary-host generation have a dagger-like ultimate rostral segment and pierce insect larvae with their stylets [37].

First-instar nymphs of horned aphids may even attack predators with their stylets. Astegopteryx bambucifoliae, on the secondary host, produces first-instar nymphs with short horns which seem to be useless for piercing enemies. Some first-instar nymphs of this species were observed piercing insect eggs and pupae with their stylets [87]. Agarwala et al. [226] report that horned aphids of Ceratovacuna silvestrii, which live on bamboo in northeastern India, cause irritation to human skin. It is still unknown whether the aphids pierce human skin with their stylets.

5.4.8. Association with Ants. Cerataphidines on their secondary hosts are often associated with ants. Colonies of those species that do not produce defensive nymphs are frequently attended by ants, especially in the tropics. Cerataphis brasiliensis on palms [190, 227], C. freycinetiae on Freycinetia sp. [71], and Astegopteryx spp. on bamboos and palms [64, $70,228]$ are examples. On the other hand, in those species that produce soldiers or defensive nymphs, their association with ants seems complicated. Colonies of the Siamese species
Pseudoregma baenzigeri on bamboo shoots often become huge and produce too much honeydew to be consumed by attending ants such as Pheidologeton trechideros, Dolichoderus thoracicus and Myrmicaria brunnea. Honeydew falling from these colonies forms a broad dark band on the forest litter [118]. This is also the case for Pseudoregma bambucicola on bamboo in Kagoshima, southern Japan [94], and $P$. alexanderi on Dendrocalamus latiflorus, in central Taiwan (our unpublished observations). Shibao et al. [99] found that many colonies of P. bambucicola on Bambusa multiplex are initially attended by the ant Lasius japonicus or Crematogaster osakensis, but most of the colonies are later abandoned by these ants. Unattended colonies, including those that were abandoned by the ants, often attain a large colony size and produce numerous soldiers. In contrast, colonies continuously attended by the ants usually remain small and have no soldiers. Shibao et al. [99] suggest that ants frequently prey upon aphids they attend, and that the aphid colony invests less in soldiers when attended by ants.

A more intimate association with ants is observed for Pseudoregma sundanica on ginger in the Malay Peninsula. This species is an obligate myrmecophile. Almost all the aphid colonies are tended by ants [205]. Most (ca. 80\%) colonies have no soldiers, but artificial exclusion of ants results in the production of soldiers or the increase in the proportion of soldiers [205]. Schütze and Maschwitz [194] 
see this ant-aphid symbiosis from a different point of view. Ants repel general predators from colonies of $P$. sundanica which they attend but do not attack lepidopteran larvae of the tribe Miletini (Lycaenidae), such as Allotinus unicolor or Miletus biggsii. These lycaenid species are specialist predators of ant-attended homopterans $[229,230]$ and are associated with particular ant species (e.g., Allotinus unicolor with Anoplolepis gracilipes, Miletus biggsii with Dolichoderus sp. [231]). Maschwitz et al. [229] suggest that soldiers defend their colony from miletine predators which tending ants do not attack.

5.5. Sexuparae. Sexuparae are those aphids that produce sexuals (oviparous females and males). In the subfamily Hormaphidinae, so far as is known, all sexuparae are alates and fliers. In the sister subfamily Eriosomatinae, one species (Eriosoma rileyi) has apterous sexuparae [232], and some (Kaltenbachiella japonica [233] and Pemphigus spyrothecae [234]) produce alate sexuparae which usually do not fly but walk to the tree trunk where their progenies mate. Such exceptions might also be found in the Hormaphidinae. Sexuparae are produced either on the secondary host (if the life cycle is host-alternating) or on the primary host (if the life cycle is non-host-alternating). They fly to leaves of the primary host, Styrax trees, and larviposit there. One sexupara usually (but not always) contains both male and female embryos.

5.6. Secondary Migrants. Secondary migrants are alate exules, or alates that migrate between secondary hostplants. In external morphology, they are very similar to alate sexuparae; they may have been derived from the latter. In some species such as Ceratovacuna cerbera [86], secondary migrants are produced only in the end of the season (in October/November) when sexuparae would be produced. In others (e.g., Ceratovacuna lanigera [116], Cerataphis brasiliensis [34]), secondary migrants are produced in various months. In species with horned exules, secondary migrants (and sexuparae) have a pair of short, often vestigial horns and can be easily distinguished from conspecific emigrants in morphology.

5.7. Sexuals. Both males and sexual (oviparous) females of the Cerataphidini are tiny and apterous. So far as is known, females each lay only one egg $[17,40,46,79,80]$. (Females of nipponaphidines [235] and hormaphidines [58] lay more than one egg.) Sexuals of the genera Tuberaphis $[11,39,40]$ and Cerataphis [34, 46] have a rather long rostrum; it is unknown whether they need plant sap for maturation. On the other hand, sexuals of the genera Pseudoregma [185], Ceratovacuna [78, 115], and Ceratoglyphina [72] and females of Astegopteryx [16] have only a short rostrum. Males of Astegopteryx (at least of A. spinocephala and A. bambucifoliae) are arostrate [17] like sexuals of the Eriosomatinae [68, 236]. Females of these cerataphidine genera can mature without feeding $[16,17,78,79,100]$. In one species (Ceratovacuna nekoashi) fighting between males for a female is reported [80].
5.8. Sex Ratio. Sex ratios of the tribe Cerataphidini have not yet been fully studied. In the host-alternating species Ceratoglyphina styracicola, female-biased investment ratios ( 0.33 and 0.42$)$ were obtained, suggesting the occurrence of local mate competition (LMC) [30]. Kurosu and Aoki [237] applied Yamaguchi's [238] ESS model, which predicts a constant number of males for each sexupara, to five cerataphidine species. Among these species, the prediction was met well in the obligately host-alternating species Ceratovacuna nekoashi: of 114 sexuparae dissected, most (>90\%) contained eight male embryos and the others seven or nine [237]. Watase [79] obtained almost the same result with 20 sexuparae of C. nekoashi. However, Yamaguchi's model requires a constant number of mother sexuparae whose offspring constitutes a breeding population. Nobody has yet succeeded in explaining how this requirement can be fulfilled. In case of C. nekoashi, alate sexuparae larviposit on leaves of Styrax japonicus, and first-instar sexuals soon move to branches where mating occurs [78]. Thus, the number of mother sexuparae is likely to vary across breeding sites and across years.

In the non-host-alternating species Astegopteryx spinocephala, the (investment) sex ratio is almost 1 to 1 (0.4640.519). As mentioned in Section 3.8.2, in this species, mating takes place in live subgalls that are guarded by soldiers. Most males are deposited on leaves and enter live subgalls for mating; thus some level of outbreeding is attained. On the other hand, because some (14-27\%) males are deposited in the natal subgalls, LMC should bias the sex ratio toward the female. Aoki et al. [133] argue that local resource competition may counteract the effects of LMC.

5.9. Eggs. Little information is available about cerataphidine eggs. They are elongate ellipsoid in shape, pale, covered with wax secreted by the mother oviparae, and approximately $0.37 \mathrm{~mm}$ long and $0.16 \mathrm{~mm}$ wide in Astegopteryx spinocephala [17] and approximately $0.38 \mathrm{~mm}$ long and $0.22 \mathrm{~mm}$ wide in Ceratovacuna nekoashi [79]. Eggs are laid in the fissures of bark in C. nekoashi $[78,79]$, or sometimes in old dead galls in Astegopteryx bambucifoliae [16]. In Nipponaphidini and Hormaphidini, eggs are often laid directly onto buds of the host tree $[58,74]$, but in Cerataphidini no such case has yet been reported. In A. spinocephala (Section 3.8.2) and Ceratoglyphina roepkei (Section 3.8.3), eggs are laid in live subgalls defended by soldiers.

Eggs of temperate species such as Ceratovacuna nekoashi (Section 3.1) have to enter diapause for hibernation. Eggs of the subtropical species Astegopteryx bambucifoliae are thought to hatch soon after being laid without entering diapause [16]. In other subtropical or tropical species with seasonal life cycles, sexuparae are at times produced out of season (Sections 3.4.3 and 3.6). It is unknown whether eggs laid by daughters of these sexuparae hatch in appropriate months for gall formation.

\section{Conclusion}

In this review, we have surveyed the life cycles of cerataphidines and illustrated various patterns found in temperate, 
subtropical and tropical regions. In conclusion, the life cycles of the tribe Cerataphidini are basically the same as those of the Eriosomatinae, which have been studied better [53], in the sense that they are classified into (1) obligate or facultative host alternation, (2) monoecy on the primary host, and (3) anholocycly on the secondary host. However, since many cerataphidines inhabit tropical and subtropical regions of Southeast Asia, they show some special features which have not been known in the Eriosomatinae.

Firstly, winter is mild or effectively absent in tropical and subtropical regions of Southeast Asia. The life cycles of tropical or subtropical cerataphidines are therefore not very rigidly tuned to seasonal changes in the climate if any. Migration from the primary host to the secondary host, for instance, often lasts over a few months (Section 3.4). Although this has not yet been definitely confirmed, the life cycles of some host-alternating species (including Cerataphis brasiliensis [34]) in tropical rainforests are alleged to be aseasonal (Section 3.7); that is, galls are formed on the primary host all the year round. The life cycles of species living in tropical monsoon and subtropical regions, on the other hand, show a clear seasonality (Sections 3.4 and 3.6). Even in tropical rainforests near the equator, the monoecious Ceratoglyphina roepkei has a distinct seasonal life cycle; perhaps its life cycles might not be synchronized across regions (Section 3.8.3). It may also be worth emphasizing here that all gall-forming cerataphidines hitherto known retain sex, whether they may be tropical, subtropical, or temperate species (of course, except for anholocycly on the secondary host). This fact does not contradict theories about sex [239-241], but earlier researchers (e.g., [52, 242]) tended to think that aphids in general propagate themselves exclusively by parthenogenesis in tropical and subtropical regions.

Secondly, cerataphidine galls in tropical and subtropical regions last at least several months, at times for over one year (Section 3.4). Even a temperate species induces biennial galls on a deciduous tree (Section 3.8.1). This is possible because they produce many sterile soldiers that effectively defend their galls (Section 5.3). They can produce many soldiers because their colony size becomes large [201-203], at times huge, more than 100,000 (Table 3 ). The colony sizes can be large because their galls become large enough to sustain many aphids. Often, cerataphidine galls are complicated in shape: twisted (Figures 6(c) and 6(d)), or coral shaped (Figures 5(a) and 12(a)), and/or with many solid projections inside (Figures 12(b)-12(e)). These features contribute to increasing the surface-to-volume ratio (cf. [243]), thus harboring more aphids per volume.

Thirdly, species of two genera of the Cerataphidini, Pseudoregma and Ceratovacuna, always and at times, respectively, produce soldiers or non-sterile nymphs that defend their colonies on the secondary host (Section 5.4.2). In addition, at least one species of Tuberaphis produces defensive nymphs on the secondary host (Section 5.4.7). Although soldiers are also known to occur on the secondary host in the eriosomatine genus Colophina [244-246], here we point out a possibility of their long-term impact upon the life cycles of Cerataphidini. The production of soldiers or defensive nymphs (as well as association with ants) has certainly lengthened colony span on the secondary host. As a result, some clones may now persist on the secondary host over years without sex, as is suggested by the success of those species (e.g., Pseudoregma bambucicola, $P$. panicola, Ceratovacuna lanigera) that have invaded regions where their primary host is lacking. In these clones, gall-forming ability is not necessary for their shortterm success, and mutations that are deleterious to the life on the primary host but neutral or beneficial to the life on the secondary host may have been accumulated. Introgression of these bad genes into the gall-forming generation through sex will decrease the rate of success in gall formation. From this "bad gene" hypothesis [237] an admittedly vague prediction is made: in tropical/subtropical regions, galls of the species that produce soldiers or defensive nymphs on the secondary host are in general rarer than galls of those that do not. This may be the reason why it is difficult to find galls of Pseudoregma in comparison with Astegopteryx.

\section{Acknowledgments}

This study was in part supported by a grant from Chuo University (to UK in fiscal years 2008 and 2009). Naomi Pierce and David Stern kindly permitted the authors to use the photo of Figure 12(e) and the photos of Figures 2(c) and 12(f), respectively. (All other photos were taken by the authors.)

\section{References}

[1] G. Remaudière and M. Remaudière, Catalogue of the World's Aphididae, Institut National de la Recherche Agronomique, Versailles, France, 1997.

[2] S. Aoki, S. Yamane, and M. Kiuchi, "On the biters of Astegopteryx styracicola (Homoptera, Aphidoidea)," Konty $\hat{u}$, vol. 45, no. 4, pp. 563-570, 1977.

[3] S. Aoki and M. Miyazaki, "Notes on the pseudoscorpion-like larvae of Pseudoregma alexanderi (Homoptera, Aphidoidea)," Kontyû, vol. 46, no. 3, pp. 433-438, 1978.

[4] S. Aoki, "Evolution of sterile soldiers in aphids," in Animal Societies: Theories and Facts, Y. Itô and J. L. Brown, Eds., pp. 53-65, Japan Scientific Societies Press, Tokyo, Japan, 1987.

[5] S. Aoki, "Soldiers, altruistic dispersal and its consequences for aphid societies," in Genes, Behavior and Evolution of Social Insects, T. Kikuchi, N. Azuma, and S. Higashi, Eds., pp. 201215, Hokkaido University Press, Sapporo, Japan, 2003.

[6] D. L. Stern and W. A. Foster, "The evolution of soldiers in aphids," Biological Reviews of the Cambridge Philosophical Society, vol. 71, no. 1, pp. 27-79, 1996.

[7] D. L. Stern and W. A. Foster, "The evolution of sociality in aphids: a clone's-eye view," in The Evolution of Social Behavior in Insects and Arachnids, J. C. Choe and B. J. Crespi, Eds., pp. 150-165, Cambridge University Press, Cambridge, UK, 1997.

[8] J. Docters van Leeuwen-Reijnvaan and W. M. Docters van Leeuwen, The Zoocecidia of the Netherlands East Indies, Drukkerij de Unie, Batavia, the Dutch East Indies, 1926.

[9] Anonymous (according to J. C. van der Meer Mohr), "Pflanzliche "Korallen"”, Natur und Museum, vol. 63, pp. 163-168, 1933.

[10] U. Kurosu and S. Aoki, "Cerataphis vandermeermohri (Homoptera), a tropical aphid with soldiers falling off their 
huge gall," Japanese Journal of Entomology, vol. 65, no. 2, pp. 278-290, 1997.

[11] U. Kurosu and S. Aoki, "Tuberaphis owadai (Homoptera), a new aphid species forming a large gall on Styrax tonkinensis in northern Vietnam," Entomological Science, vol. 6, no. 2, pp. 89-96, 2003.

[12] A. F. G. Dixon, Aphid Ecology, Blackie, Glasgow, UK, 1st edition, 1985.

[13] A. F. G. Dixon, Aphid Ecology: An Optimization Approach, Chapman \& Hall, London, UK, 2nd edition, 1998.

[14] J. T. Costa, The Other Insect Societies, Belknap Press of Harvard University Press, Cambridge, Mass, USA, 2006.

[15] N. Pike and W. A. Foster, "The ecology of altruism in a clonal insect," in Ecology of Social Evolution, J. Korb and J. Heinze, Eds., pp. 37-56, Springer, Berlin, Germany, 2008.

[16] U. Kurosu and S. Aoki, "The gall formation, defenders and life cycle of the subtropical aphid Astegopteryx bambucifoliae (Homoptera)," Japanese Journal of Entomology, vol. 59, no. 2, pp. 375-388, 1991.

[17] U. Kurosu, S. Buranapanichpan, and S. Aoki, “Astegopteryx spinocephala (Hemiptera: Aphididae), a new aphid species producing sterile soldiers that guard eggs laid in their gall," Entomological Science, vol. 9, no. 2, pp. 181-190, 2006.

[18] D. L. Stern, "Phylogenetic evidence that aphids, rather than plants, determine gall morphology," Proceedings of the Royal Society B, vol. 260, no. 1357, pp. 85-89, 1995.

[19] U. Kurosu, K. Matsumoto, and S. Aoki, "Host alternation of two tropical gall-forming aphids, Astegopteryx styracophila and A. pallida (Homoptera)," Entomological Science, vol. 1, no. 1, pp. 21-26, 1998.

[20] U. Kurosu and S. Aoki, "Gall formation, outsiders and soldiers of the aphid Ceratovacuna japonica (Homoptera)," Japanese Journal of Entomology, vol. 62, no. 4, pp. 793-802, 1994.

[21] U. Kurosu and S. Aoki, "Formation of a "cat's-paw" gall by the aphid Ceratovacuna nekoashi (Homoptera)," Japanese Journal of Entomology, vol. 58, no. 1, pp. 155-166, 1990.

[22] C. C. Tao, "Revision of Chinese Hormaphinae, Aphidae, Homoptera," Quarterly Journal of Taiwan Museum, vol. 19, no. 1-2, pp. 165-179, 1966.

[23] H. Okamoto and R. Takahashi, "Some Aphididae from Corea," Insecta Matsumurana, vol. 1, no. 3, pp. 130-148, 1927.

[24] W. H. Paik, Illustrated Encyclopedia of Fauna and Flora of Korea, Volume 13, Insecta (V), Samwha Publishing, Seoul, Republic of Korea, 1972.

[25] J. Docters van Leeuwen-Reijnvaan and W. M. Docters van Leeuwen, "The Zoocecidia of the Netherlands' East Indies, Supplement I," Nederlandsch Kruidkundig Archief, vol. 51, pp. 122-251, 1941.

[26] S. Aoki and U. Kurosu, "Gall generations of the soldierproducing aphid Pseudoregma bambucicola (Homoptera)," Japanese Journal of Entomology, vol. 60, no. 2, pp. 359-368, 1992.

[27] S. Aoki and U. Kurosu, "Host alternation of the aphid Pseudoregma koshunensis (Homoptera) in Taiwan," New Entomologist, vol. 40, no. 3-4, pp. 31-33, 1991.

[28] S. Aoki, U. Kurosu, S. Buranapanichpan, H. Bänziger, and T. Fukatsu, "Discovery of the gall generation of the tropical bamboo aphid Pseudoregma carolinensis (Hemiptera) from northern Thailand," Entomological Science, vol. 5, no. 1, pp. 55-61, 2002.
[29] U. Kurosu and S. Aoki, "Discovery of the gall generation of the ginger aphid Pseudoregma sundanica (Homoptera)," Entomological Science, vol. 4, no. 2, pp. 209-215, 2001.

[30] U. Kurosu and S. Aoki, "Long-lasting galls of Ceratoglyphina styracicola, a host-alternating subtropical aphid species," in Aphids in Natural and Managed Ecosystems, J. M. Nieto Nafría and A. F. G. Dixon, Eds., pp. 227-234, Universidad de León (Secretariado de Publicaciones), 1998.

[31] D. L. Stern, S. Aoki, and U. Kurosu, "Determining aphid taxonomic affinities and life cycles with molecular data: a case study of the tribe Cerataphidini (Hormaphididae: Aphidoidea: Hemiptera)," Systematic Entomology, vol. 22, no. 1, pp. 81-96, 1997.

[32] S. Aoki, U. Kurosu, T. Partomihardjo, S. Kahono, and P. O. Ngakan, "Cerataphidini (Homoptera, Aphididae) from Sulawesi," Japanese Journal of Systematic Entomology, vol. 8, no. 1, pp. 115-118, 2002.

[33] U. Kurosu, M. Kutsukake, S. Aoki, C. C. Wang, H. J. Lee, and T. Fukatsu, "Galls of Cerataphis bambusifoliae (Hemiptera, Aphididae) found on Styrax suberifolius in Taiwan," Zoological Studies, vol. 47, no. 2, pp. 191-199, 2008.

[34] D. L. Stern, S. Aoki, and U. Kurosu, "The life cycle and natural history of the tropical aphid Cerataphis fransseni (Homoptera: Aphididae: Hormaphidinae), with reference to the evolution of host alternation in aphids," Journal of Natural History, vol. 29, no. 1, pp. 231-242, 1995.

[35] S. Aoki, U. Kurosu, T. Fukatsu, and H. Ishikawa, "Cerataphis jamuritsu, a subtropical aphid producing soldiers in large, hard galls (Homoptera)," Entomological Science, vol. 1, no. 3, pp. 327-333, 1998.

[36] S. Aoki and S. Usuba, "Rediscovery of "Astegopteryx" takenouchii (Homoptera, Aphidoidea), with notes on its soldiers and hornless exules," Japanese Journal of Entomology, vol. 57, no. 3, pp. 497-503, 1989.

[37] U. Kurosu, S. Aoki, and T. Fukatsu, "Taxonomic position of the aphid "Astegopteryx takenouchii" (Homoptera), with notes on its defenders on the secondary host," Japanese Journal of Entomology, vol. 62, no. 2, pp. 363-368, 1994.

[38] S. Aoki and U. Kurosu, "The gall, soldiers and taxonomic position of the aphid Tuberaphis taiwana (Homoptera)," Japanese Journal of Entomology, vol. 61, pp. 361-369, 1993.

[39] S. Aoki and U. Kurosu, "Soldiers of Astegopteryx styraci (Homoptera, Aphidoidea) clean their gall," Japanese Journal of Entomology, vol. 57, no. 2, pp. 407-416, 1989.

[40] S. Aoki, U. Kurosu, T. Nagashima, and T. Fukatsu, "Tuberaphis leeuweni (Homoptera), a tropical, monoecious, gall-forming aphid with soldier-like nymphs," Japanese Journal of Entomology, vol. 63, no. 1, pp. 77-86, 1995.

[41] D. Hille Ris Lambers, "Two new species of Astegopteryx Karsch from Styrax," Miscellanea Zoologica Sumatrana, no. 55, pp. 1-5, 1931.

[42] D. Noordam, "Hormaphidinae from Java (Homoptera: Aphididae)," The Zoologische Verhandelingen, no. 270, pp. 1-525, 1991.

[43] R. Takahashi, "List of the Aphididae of the Malay Peninsula, with descriptions of new species (Homoptera)," Annals of the Entomological Society of America, vol. 43, no. 4, pp. 587-607, 1950.

[44] S. Aoki and U. Kurosu, "Banana, a secondary host of the aphid Astegopteryx styracophila (Homoptera, Aphididae, Hormaphidinae)," Rostria, no. 47, pp. 51-52, 1998.

[45] H. T. Liao, "Bamboo aphids of Taiwan," Quarterly Journal of the Taiwan Museum, vol. 29, no. 3-4, pp. 499-586, 1976. 
[46] U. Kurosu, T. Fukatsu, and S. Aoki, "Sexuparae of the bamboo aphid Cerataphis bambusifoliae (Homoptera, Aphidoidea)," Japanese Journal of Entomology, vol. 64, no. 4, pp. 918-923, 1996.

[47] M. B. Stoetzel and D. J. Hilburn, "The aphids and phylloxera of Bermuda (Homoptera: Aphididae and Phylloxeridae)," The Florida Entomologist, vol. 73, no. 4, pp. 627-643, 1990.

[48] H. Bänziger, "More aphids (Homoptera, Aphidoidea) collected in Thailand (1978-1984)," The Natural History Bulletin of the Siam Society, vol. 33, no. 2, pp. 103-119, 1985.

[49] R. Takahashi, "Three interesting aphids from the Far East," Stylops, vol. 2, no. 2, pp. 27-30, 1933.

[50] W. Wojciechowski, Studies on the Systematic System of Aphids (Homoptera, Aphidinea), Uniwersytet Slaski, Katowice, Poland, 1992.

[51] B. Ortiz-Rivas and D. Martínez-Torres, "Combination of molecular data support the existence of three main lineages in the phylogeny of aphids (Hemiptera: Aphididae) and the basal position of the subfamily Lachninae," Molecular Phylogenetics and Evolution, vol. 55, no. 1, pp. 305-317, 2010.

[52] A. K. Mordvilko, "Die Blattläuse mit unvollständigem Generationszyklus und ihre Entstehung," Ergebnisse und Fortschritte der Zoologie, vol. 8, pp. 36-328, 1935.

[53] G. Lampel, Die Biologie des Blattlaus-Generationswechsels, VEB Gustav Fischer, Jena, Germany, 1968.

[54] R. L. Blackman and V. F. Eastop, Aphids on the World's Trees: An Identification and Information Guide, CAB International, Wallingford, UK, 1994.

[55] H.-T. Yeh, Biosystematics and molecular phylogeny of the Hormaphidinae (Hemiptera: Aphididae) in Taiwan, Ph.D. thesis, National Taiwan University, 2009.

[56] D. L. Stern, "A phylogenetic analysis of soldier evolution in the aphid family Hormaphididae," Proceedings of the Royal Society B, vol. 256, no. 1346, pp. 203-209, 1994.

[57] M. Sorin and M. Miyazaki, "Aleurodaphis of Japan (Hemiptera, Aphididae)," Japanese Journal of Systematic Entomology, vol. 10, no. 2, pp. 165-177, 2004.

[58] T. Pergande, The Life History of Two Species of Plant-Lice Inhabiting Both the Witch-Hazel and Birch, U.S. Department of Agriculture, Division of Entomology, Technical Series, no. 9, Govt. print. off, 1901.

[59] S. Aoki, C. D. von Dohlen, and U. Kurosu, "Revision of the Japanese species of the aphid genus Hamamelistes (Hemiptera, Aphididae, Hormaphidinae) based on the mitochondrial DNA sequence data," Entomological Science, vol. 4, no. 1, pp. 59-67, 2001.

[60] T. Fukatsu, S. Aoki, U. Kurosu, and H. Ishikawa, "Phylogeny of Cerataphidini aphids revealed by their symbiotic microorganisms and basic structure of their galls: implications for host-symbiont coevolution and evolution of sterile soldier castes," Zoological Science, vol. 11, no. 4, pp. 613-623, 1994.

[61] D. L. Stern, "Phylogeny of the tribe Cerataphidini (Homoptera) and the evolution of the horned soldier aphids," Evolution, vol. 52, no. 1, pp. 155-165, 1998.

[62] Y. Hongoh and H. Ishikawa, "Evolutionary studies on uricases of fungal endosymbionts of aphids and planthoppers," Journal of Molecular Evolution, vol. 51, no. 3, pp. 265-277, 2000.

[63] S. Matsumura, "Synopsis of the Pemphigidae of Japan," in $A$ Collection of Essays for Mr. Yasushi Nawa, K. Nagano, Ed., pp. 39-94, Gifu, Japan, 1917.

[64] P. van der Goot, "Zur Kenntnis der Blattläuse Java's," Contributions a la Fauna des Indes Néderlandaises, vol. 1, no. 3, pp. 1-301, 1917.
[65] W. M. Docters van Leeuwen, "Ueber eine neue Styrax-Galle aus Borneo und Celebes," Tijdschrift vor Entomologie, vol. 75, supplement, pp. 97-99, 1932.

[66] P. W. Fritsch, "Phylogeny and biogeography of the flowering plant genus Styrax (Styracaceae) based on chloroplast DNA restriction sites and DNA sequences of the internal transcribed spacer region," Molecular Phylogenetics and Evolution, vol. 19, no. 3, pp. 387-408, 2001.

[67] Y. Huang, P. W. Fritsch, and S. Shi, "A revision of the imbricate group of Styrax series Cyrta (Styracaceae) in Asia," Annals of the Missouri Botanical Garden, vol. 90, no. 4, pp. 491-553, 2003.

[68] V. F. Eastop, "A taxonomic study of Australian Aphidoidea (Homoptera)," Australian Journal of Zoology, vol. 14, no. 3, pp. 399-592, 1966.

[69] O. E. Heie, The Aphidoidea (Hemiptera) of Fennoscandia and Denmark, vol. 1, Scandinavian Science Prerss, Klampenborg, Denmark, 1980.

[70] R. L. Blackman and V. F. Eastop, Aphids on the World's Crops: an Identification and Information Guide, Wiley, Chichester, UK, 2nd edition, 2000.

[71] U. Kurosu and S. Aoki, "Record of two Cerataphis species (Homoptera, Aphididae) from southern Japan," Rostria, no. 53, pp. 45-47, 2006.

[72] U. Kurosu and S. Aoki, "Monoecious life cycle of the tropical aphid Astegopteryx roepkei (Homoptera)," Japanese Journal of Entomology, vol. 63, no. 1, pp. 51-52, 1995.

[73] S. Aoki and U. Kurosu, "Biennial galls of the aphid Astegopteryx styraci on a temperate deciduous tree, Styrax obassia," Acta Phytopathologica et Entomologica Hungarica, vol. 25, no. 1-4, pp. 57-65, 1990.

[74] U. Kurosu and S. Aoki, "Extremely long-closed galls of a social aphid," Psyche, vol. 2009, Article ID 268756, 9 pages, 2009.

[75] S. W. Phillips, J. S. Bale, and G. M. Tatchell, "Escaping an ecological dead-end: asexual overwintering and morph determination in the lettuce root aphid Pemphigus bursarius L.," Ecological Entomology, vol. 24, no. 3, pp. 336-344, 1999.

[76] N. J. Miller, N. B. Kift, and G. M. Tatchell, "Host-associated populations in the lettuce root aphid, Pemphigus bursarius (L.)," Heredity, vol. 94, no. 5, pp. 556-564, 2005.

[77] J. Urban, "Bionomics and harmfulness of Tetraneura ulmi (L.) (Aphidinea, Pemphigidae) in elms," Journal of Forest Science, vol. 49, no. 4, pp. 159-181, 2003.

[78] U. Kurosu and S. Aoki, "Non-feeding sexuales of Ceratovacuna nekoashi (Homoptera, Aphidoidea)," Japanese Journal of Entomology, vol. 58, no. 4, pp. 831-834, 1990.

[79] A. Watase, "Studies on the Styrax gall aphids, Ceratovacuna nekoashi Sasaki (part 1): notes on the sexual characters and oviposition," Journal of Agricultural Science, vol. 7, no. 1, pp. 15-19, 1961 (Japanese).

[80] U. Kurosu, "Sexual reproduction in aphids and the prosperity and decline of their galls," in Tales about the Male and Female in Insects, K. Umeya, Ed., pp. 64-72, Gihodo-Shuppan, Tokyo, Japan, 1992.

[81] S. Aoki and U. Kurosu, "Discovery of the gall generation of Ceratovacuna japonica (Homoptera: Aphidoidea)," Akitu, no. 122, pp. 1-6, 1991.

[82] H. Higuchi and M. Miyazaki, "A tentative catalogue of host plants of Aphidoidea in Japan," Insecta Matsumurana, Supplement, no. 5, pp. 1-66, 1971.

[83] M. Hattori and T. Itino, “Soldiers' armature changes seasonally and locally in an eusocial aphid (Homoptera: Aphididae)," Sociobiology, vol. 52, no. 2, pp. 429-436, 2008. 
[84] N. F. Carlin, D. S. Gladstein, A. J. Berry, and N. E. Pierce, "Absence of kin discrimination behavior in a soldierproducing aphid, Ceratovacuna japonica (Hemiptera: Pemphigidae; Cerataphidini)," Journal of the New York Entomological Society, vol. 102, no. 3, pp. 287-298, 1994.

[85] R. Takahashi, "On the aphids of Ceratovacuna in Japan (Aphididae, Homoptera)," Kontyû, vol. 26, no. 4, pp. 187190, 1958.

[86] S. Aoki, U. Kurosu, K. Y. Shin, and J. C. Choe, "A new soldierproducing species of Ceratovacuna (Homoptera, Aphididae, Hormaphidinae) on Sasa spp. from Japan and Korea," Entomological Science, vol. 2, no. 4, pp. 511-516, 1999.

[87] S. Aoki and U. Kurosu, "A bamboo horned aphid attacking other insects with its stylets," Japanese Journal of Entomology, vol. 57, no. 3, pp. 663-665, 1989.

[88] C. C. Wang, S. C. Tsaur, U. Kurosu, S. Aoki, and H. J. Lee, "Social parasitism and behavioral interactions between two gall-forming social aphids," Insectes Sociaux, vol. 55, no. 2, pp. 147-152, 2008.

[89] S. Aoki and U. Kurosu, "Host alternation of two Taiwanese cerataphidines (Homoptera: Aphidoidea)," Akitu, no. 107, pp. 1-11, 1989.

[90] T. Sunose, S. Yamane, K. Tsuda, and K. Takasu, "What do the soldiers of Pseudoregma bambucicola (Homoptera, Aphidoidea) defend?" Japanese Journal of Entomology, vol. 59, no. 1, pp. 141-148, 1991.

[91] K. Ohara, "Observations on the oviposition behaviour of Metasyrphus confrater (Diptera, Syrphidae) and the defensive behaviour of soldiers of Pseudoregma bambucicola (Homoptera, Pemphigidae)," Esakia, no. 23, pp. 99-105, 1985.

[92] K. Ôhara, "Observations on the prey-predator relationship between Pseudoregma bambucicola (Homoptera, Pemphigidae) and Metasyrphus confrater (Diptera, Syrphidae) with special reference to the behaviour of the aphid soldiers," Esakia, no. 23, pp. 107-110, 1985.

[93] K. Sakata and Y. Itô, "Life history characteristics and behaviour of the bamboo aphid, Pseudoregma bambucicola (Hemiptera: Pemphigidae), having sterile soldiers," Insectes Sociaux, vol. 38, no. 3, pp. 317-326, 1991.

[94] K. Sakata, Y. Itô, J. Yukawa, and S. Yamane, "Ratio of sterile soldiers in the bamboo aphid, Pseudoregma bambucicola (Homoptera: Aphididae), colonies in relation to social and habitat conditions," Applied Entomology and Zoology, vol. 26, no. 4, pp. 463-468, 1991.

[95] Y. Itô, S. Tanaka, J. Yukawa, and K. Tsuji, "Factors affecting the proportion of soldiers in eusocial bamboo aphid, Pseudoregma bambucicola, colonies," Ethology Ecology and Evolution, vol. 7, no. 4, pp. 335-345, 1995.

[96] S. Tanaka and Y. Itô, "Interrelationships between the eusocial aphid, Pseudoregma bambucicola, and its syrphid predator, Eupeodes confrater," Japanese Journal of Entomology, vol. 63, no. 1, pp. 221-228, 1995.

[97] H. Shibao, "Social structure and the defensive role of soldiers in a eusocial bamboo aphid, Pseudoregma bambucicola (Homoptera: Aphididae): a test of the defence-optimization hypothesis," Researches on Population Ecology, vol. 40, no. 3, pp. 325-333, 1998.

[98] H. Shibao, "Reproductive schedule and factors affecting soldier production in the eusocial bamboo aphid Pseudoregma bambucicola (Homoptera, Aphididae)," Insectes Sociaux, vol. 46, no. 4, pp. 378-386, 1999.

[99] H. Shibao, M. Morimoto, Y. Okumura, and M. Shimada, "Fitness costs and benefits of ant attendance and soldier production for the social aphid Pseudoregma bambucicola (Homoptera: Aphididae: Hormaphidinae)," Sociobiology, vol. 54, no. 3, pp. 673-698, 2009.

[100] U. Kurosu and S. Aoki, "Immature galls of the subtropical aphid Pseudoregma bambucicola (Homoptera), with notes on the soldiers and first-instar fundatrices," Special Bulletin of the Japanese Society of Coleopterology, no. 4, pp. 207-211, 1995.

[101] S. Aoki and U. Kurosu, "Galls of the soldier-producing aphid Ceratoglyphina bambusae broken by vertebrates (Homoptera, Aphidoidea)," Japanese Journal of Entomology, vol. 59, no. 4, pp. 743-746, 1991.

[102] S. Aoki and U. Kurosu, "No attack on conspecifics by soldiers of the gall aphid Ceratoglyphina bambusae (Homoptera) late in the season," Japanese Journal of Entomology, vol. 60, no. 4, pp. 707-713, 1992.

[103] U. Kurosu and S. Aoki, "Transformation of the galls of Astegopteryx bambucifoliae by another aphid, Ceratoglyphina bambusae," Acta Phytopathologica et Entomologica Hungarica, vol. 25, no. 1-4, pp. 113-122, 1990.

[104] U. Kurosu and S. Aoki, "Incipient galls of the soldierproducing aphid Ceratoglyphina bambusae (Homoptera)," Japanese Journal of Entomology, vol. 59, no. 3, pp. 663-669, 1991.

[105] U. Kurosu and S. Aoki, "Molting soldiers of the gall aphid Ceratoglyphina bambusae (Homoptera)," Japanese Journal of Entomology, vol. 59, no. 3, p. 576, 1991.

[106] S. Aoki, U. Kurosu, and D. L. Stern, "Aphid soldiers discriminate between soldiers and non-soldiers, rather than between kin and non-kin, in Ceratoglyphina bambusae," Animal Behaviour, vol. 42, no. 5, pp. 865-866, 1991.

[107] Y. Yoshiyasu, "A new species of Assara (Lepidoptera, Pyralidae) associated with the aphid gall," Tyô to $G a$, vol. 42, no. 4, pp. 261-269, 1991.

[108] S. Aoki, "Further observations on Astegopteryx styracicola (Homoptera: Pemphigidae), an aphid species with soldiers biting man," Kontyû, vol. 47, no. 2, pp. 99-104, 1979.

[109] R. Takahashi, "An aphid species biting man," Transactions of the Natural History Society of Formosa, vol. 20, no. 106, pp. 43-44, 1930 (Japanese).

[110] R. L. Blackman and V. F. Eastop, Aphids on the World's Herbaceous Plants and Shrubs, Volume 2, The Aphids, Wiley, Chichester, UK, 2006.

[111] R. Takahashi, "Aphididae of Formosa, part II," Report of Department of Agriculture, Government Research Institute, Formosa, no. 4, pp. 1-173, 1923.

[112] S. Azuma, "Biological studies on the sugar cane insect pests in Okinawa, with special reference to the change of their composition and infestation in relation to the introduction of new commercial sugar cane varieties," The Science Bulletin of the College of Agriculture, University of Ryukyus, no. 24, pp. 1-158, 1977 (Japanese).

[113] Y. Matsumoto, "Overwintering of Ceratovacuna lanigera Zehntner (Homoptera: Aphididae) in Chiba Prefecture, central Japan," Rostria, no. 39, pp. 640-642, 1988 (Japanese).

[114] N. Arakaki, "Seasonal occurrence of the sugar cane woolly aphid, Ceratovacuna lanigera (Homoptera: Aphididae), and its predators in sugar cane fields of Okinawa Island," Applied Entomology and Zoology, vol. 27, no. 1, pp. 99-105, 1992.

[115] U. Kurosu and S. Aoki, "Sexuparae of the sugarcane wooly aphid Ceratovacuna lanigera," Kontyû, vol. 54, no. 3, pp. 523524, 1986.

[116] N. Arakaki, "Behavioral studies on the colony defence by the sugar cane woolly aphid Ceratovacuna lanigera against 
the predators," Bulletin of the Okinawa Agricultural Experiment Station, no. 19, pp. 77-127, 1997 (Japanese).

[117] T. Fukatsu, H. Shibao, N. Nikoh, and S. Aoki, "Genetically distinct populations in an Asian soldier-producing aphid, Pseudoregma bambucicola (Homoptera: Aphididae), identified by DNA fingerprinting and molecular phylogenetic analysis," Molecular Phylogenetics and Evolution, vol. 18, no. 3, pp. 423-433, 2001.

[118] S. Aoki, U. Kurosu, and W. Sirikajornjaru, "A new soldierproducing aphid species, Pseudoregma baenzigeri, sp. nov., from northern Thailand," Journal of Insect Science, vol. 7, no. 38, pp. 1-10, 2007.

[119] J. P. Doncaster, "Notes on some Indian aphids described by G. B. Buckton," The Entomologist, vol. 99, pp. 157-160, 1966.

[120] M. R. Ghosh, P. K. Pal, and D. N. Raychaudhuri, "Studies on the aphids from Eastern India, 21, the genus Astegopteryx Karsch and other related genera (Hormaphidinae), with descriptions of three new genera and two new species," Proceedings of the Zoological Society, vol. 27, no. 2, pp. 81$116,1974$.

[121] A. K. Ghosh, Fauna of India and the Adjacent Countries, Homoptera, Aphidoidea, Part 4, Subfamilies Phloemyzinae, Anoeciinae and Hormaphidinae, Zoological Survey of India, Calcutta, India, 1988.

[122] W. M. Docters van Leeuwen, "Ueber einige von Aphiden an Styrax-Arten gebildete Gallen," Bulletin du Jardin Botanique de Buitenzorg, vol. 4, no. 1, pp. 147-162, 1922.

[123] C. G. G. J. van Steenis, "Styracaceae," Flora Malaysiana, vol. 4, no. 2, pp. 49-56, 1949.

[124] A. F. G. Dixon, P. Kindlmann, J. Leps, and J. Holman, "Why there are so few species of aphids, especially in the tropics," The American Naturalist, vol. 129, no. 4, pp. 580-592, 1987.

[125] O. E. Heie, "Why are there so few aphid species in the temperate areas of the southern hemisphere," European Journal of Entomology, vol. 91, no. 1, pp. 127-133, 1994.

[126] J. A. Reinert and N. L. Woodiel, "Palm aphid control on 'Malayan dwarf' coconut palms," The Florida Entomologist, vol. 57, no. 4, pp. 411-413, 1974.

[127] D. A. Enobakhare, "Occurrence and distribution of Cerataphis palmae (Ghesquierei) (Homoptera: Pemphigidae) on Raphia palms in southern Nigeria," Insect Science and Its Application, vol. 15, no. 1, pp. 101-104, 1994.

[128] F. W. Howard, D. Moore, R. M. Giblin-Davis, and R. G. Abad, Insects on Palms, CAB International, Wallingford, UK, 2001.

[129] D. Hille Ris Lambers, "On the species of Astegopteryx Karsch from Styrax benzoin Dryand," Miscellanea Zoologica Sumatrana, no. 76, pp. 1-4, 1933.

[130] D. L. Stern, S. Aoki, and U. Kurosu, "A test of geometric hypotheses for soldier investment patterns in the gall producing tropical aphid Cerataphis fransseni (Homoptera, Hormaphididae)," Insectes Sociaux, vol. 41, no. 4, pp. 457460, 1994.

[131] H. Shibao, M. Kutsukake, S. Matsuyama, T. Suzuki, M. Shimada, and T. Fukatsu, "Mechanism of caste differentiation and control in an aphid social system," in Frontiers in Life Sciences, M. Fujiwara, S. Ishiura, and N. Sato, Eds., pp. 127145, Research Signpost, Kerela, India, 2006.

[132] U. Kurosu, J. Narukawa, S. Buranapanichpan, and S. Aoki, "Head-plug defense in a gall aphid," Insectes Sociaux, vol. 53, no. 1, pp. 86-91, 2006.

[133] S. Aoki, U. Kurosu, and S. Buranapanichpan, "Female production within the gall and male production on leaves by individual alates of a social aphid," Insectes Sociaux, vol. 54, no. 4, pp. 356-362, 2007.
[134] D. Hille Ris Lambers, "A new species of Astegopteryx Karsch from Styrax paralleloneurus Perk," Miscellanea Zoologica Sumatrana, no. 64, pp. 1-3, 1932.

[135] J. A. Dunn, "The formation of galls by some species of Pemphigus (Homoptera: Aphididae)," Marcellia, vol. 30, supplement, pp. 155-167, 1960.

[136] R. Takahashi, "A new aphid of the genus Astegopteryx Karsch (Hemiptera, Aphididae)," Mushi, vol. 7, no. 2, pp. 68-73, 1934.

[137] S. Nakamura, K. Iida, and Y. Degawa, "First record of the leafgall produced by the secondary-host generation of Tuberaphis takenouchii from Japan," Natural History Report of Kanagawa, no. 31, pp. 51-54, 2010 (Japanese).

[138] U. Kurosu and S. Aoki, "First-instar aphids produced late by the fundatrix of Ceratovacuna nekoashi (Homoptera) defend their closed gall outside," Journal of Ethology, vol. 6, no. 2, pp. 99-104, 1988.

[139] O. Deguchi, "Abnormal flowers of Styrax japonica," Collecting and Breeding, vol. 11, no. 4, pp. 112-113, 1949 (Japanese).

[140] O. Deguchi, "On the fructification of abnormal flowers of Styrax japonica," Collecting and Breeding, vol. 12, no. 12, p. 392, 1950 (Japanese).

[141] D. Weigel and O. Nilsson, "A developmental switch sufficient for flower initiation in diverse plants," Nature, vol. 377, no. 6549, pp. 495-500, 1995.

[142] B. Glover, Understanding Flowers and Flowering: An Integrated Approach, Oxford University Press, Oxford, UK, 2007.

[143] R. Takahashi, "A new aphid producing galls in Formosa," Zoological Magazine, vol. 51, no. 7, pp. 425-427, 1939 (Japanese).

[144] N. Pike, D. Richard, and W. Foster, "How aphids lose their marbles," Proceedings of the Royal Society of London, Series B, vol. 269, no. 1497, pp. 1211-1215, 2002.

[145] U. Kurosu, D. L. Stern, and S. Aoki, "Agonistic interactions between ants and gall-living soldier aphids," Journal of Ethology, vol. 8, no. 2, pp. 139-141, 1990.

[146] U. Kurosu, S. Aoki, and T. Fukatsu, "Self-sacrificing gall repair by aphid nymphs," Proceedings of the Royal Society of London, Series B, vol. 270, pp. S12-S14, 2003.

[147] M. Kutsukake, H. Shibao, K. Uematsu, and T. Fukatsu, "Scab formation and wound healing of plant tissue by soldier aphid," Proceedings of the Royal Society of London, Series B, vol. 276, no. 1662, pp. 1555-1563, 2009.

[148] N. Pike and W. Foster, "Fortress repair in the social aphid species, Pemphigus spyrothecae," Animal Behaviour, vol. 67, no. 5, pp. 909-914, 2004.

[149] B. Shibata, "Ecological cycle of plant lice," Shokubutsu Boeki, vol. 5, no. 10, pp. 376-379, 1951 (Japanese).

[150] B. Shibata, "Ecological studies of plant lice (IX) with special reference to the ecological cycle," Bulletin of the College of Agriculture, Utsunomiya University, vol. 3, no. 1, pp. 1-8, 1955 (Japanese).

[151] D. Hille Ris Lambers, "Notes on aphids from Cocos nucifera," Agricultural Journal, vol. 24, no. 3-4, pp. 1-3, 1953.

[152] S. Aoki, U. Kurosu, and C. D. von Dohlen, "Colony defense by wingpadded nymphs in Grylloprociphilus imbricator (Hemiptera: Aphididae)," The Florida Entomologist, vol. 84, no. 3, pp. 431-434, 2001.

[153] S. Aoki, "Pseudoscorpion-like second instar larvae of Pseudoregma shitosanensis (Homoptera, Aphidoidea) found on its primary host," Kontŷu, vol. 50, no. 3, pp. 445-453, 1982.

[154] M. Kutsukake, H. Shibao, N. Nikoh et al., "Venomous protease of aphid soldier for colony defense," Proceedings 
of the National Academy of Sciences of the United States of America, vol. 101, no. 31, pp. 11338-11343, 2004.

[155] M. Kutsukake, N. Nikoh, H. Shibao, C. Rispe, J. C. Simon, and T. Fukatsu, "Evolution of soldier-specific venomous protease in social aphids," Molecular Biology and Evolution, vol. 25, no. 12, pp. 2627-2641, 2008.

[156] H. Shibao, M. Kutsukake, S. Matsuyama, T. Suzuki, and T. Fukatsu, "Warning pheromone excreted for reinforcementsoldier deployment system of eusocial aphid by a chemical substance," Kagaku to Seibutsu, vol. 43, no. 1, pp. 4-6, 2005 (Japanese).

[157] W. S. Bowers, L. R. Nault, R. E. Webb, and S. R. Dutky, "Aphid alarm pheromone: isolation, identification, synthesis," Science, vol. 177, no. 4054, pp. 1121-1122, 1972.

[158] L. J. Edwards, J. B. Siddall, L. L. Dunham, P. Uden, and C. J. Kislow, "Trans- $\beta$-farnesene, alarm pheromone of the green peach aphid, Myzus persicae (Sulzer)," Nature, vol. 241, no. 5385, pp. 126-127, 1973.

[159] N. J. Vandenberg, "Homonymy in the Coccinellidae (Coleoptera), or something fishy about Pseudoscymnus Chapin," Proceedings of the Entomological Society of Washington, vol. 106, no. 2, pp. 483-484, 2004.

[160] H. Kamiya, "A revision of the tribe Scymnini from Japan and the Loochoos (Coleoptera: Coccinellidae), Part II. Genus Scymnus (Subgenus Pullus)," Journal of the Faculty of Agriculture, Kyushu University, vol. 11, no. 3, pp. 303-330, 1961.

[161] H. Sasaji, "On the Coccinellidae attacking the aphids in Japan and the Ryukyus," Mushi, vol. 40, no. 12, pp. 147-175, 1967.

[162] A. E. Stubbs and S. J. Falk, British Hoverflies: An Illustrated Identification Guide, British Entomological and Natural History Society, London, UK, 2nd edition, 2002.

[163] L. S. Chou, Y. S. Lin, and H. K. Mok, "Study of the maintenance behavior of the red-bellied tree squirrel Callosciurus erythraeus," Bulletin of the Institute of Zoology, Academica Sinica, vol. 24, no. 1, pp. 39-50, 1985.

[164] D. A. Hill, P. W. Lucas, and P. Y. Cheng, "Bite forces used by Japanese macaques (Macaca fuscata yakui) on Yakushima Island, Japan to open aphid-induced galls on Distylium racemosum (Hamamelidaceae)," Journal of Zoology, vol. 237, no. 1, pp. 57-63, 1995.

[165] T. Sunose, "Predation by tree-sparrow (Passer montanus L.) on gall-making aphids," Konty $\hat{u}$, vol. 48, no. 3, pp. 362-369, 1980.

[166] M. Burstein and D. Wool, "Great tits exploit aphid galls as a source of food," Ornis Scandinavica, vol. 23, no. 1, pp. 107109, 1992.

[167] S. Aoki, "Soldiers and altruistic dispersal in aphids," in The Biology of Social Insects, M. D. Breed, C. D. Michener, and H. E. Evans, Eds., pp. 154-158, Westview Press, Boulder, Colo, USA, 1982.

[168] S. Aoki, "Dimorphic first instar larvae produced by the fundatrix of Pachypappa marsupialis (Homoptera)," Kontyû, vol. 47, no. 3, pp. 390-398, 1979.

[169] R. W. Setzer, "Intergall migration in the aphid genus Pemphigus," Annals of the Entomological Society of America, vol. 73, no. 3, pp. 327-331, 1980.

[170] P. Abbot, J. H. Withgott, and N. A. Moran, "Genetic conflict and conditional altruism in social aphid colonies," Proceedings of the National Academy of Sciences of the United States of America, vol. 98, no. 21, pp. 12068-12071, 2001.

[171] P. C. D. Johnson, J. A. Whitfield, W. A. Foster, and W. Amos, "Clonal mixing in the soldier-producing aphid Pemphigus spyrothecae (Hemiptera: Aphididae)," Molecular Ecology, vol. 11, no. 8, pp. 1525-1531, 2002.

[172] K. Ozaki, "Intergall migration in aphids: a model and a test of ESS dispersal rate," Evolutionary Ecology, vol. 9, no. 5, pp. 542-549, 1995.

[173] H. Shibao, M. Kutsukake, J. M. Lee, and T. Fukatsu, "Analysis of age polyethism in a soldier-producing aphid, Tuberaphis styraci, on an artificial diet," in Aphids in a New Millennium, J.-C. Simon, C. A. Dedryver, C. Rispe, and M. Hullé, Eds., pp. 73-77, INRA, Versailles, France, 2004.

[174] U. Kurosu and S. Aoki, "Gall cleaning by the aphid Hormaphis betulae," Journal of Ethology, vol. 9, no. 2, pp. 51$55,1991$.

[175] H. Shibao and T. Fukatsu, "Altruistic defenders in a gallforming aphid of the tribe Hormaphidini (Homoptera, Aphididae, Hormaphidinae) on its primary host," Insectes Sociaux, vol. 50, no. 2, pp. 167-173, 2003.

[176] S. Aoki, "Occurrence of a simple labor in a gall aphid,

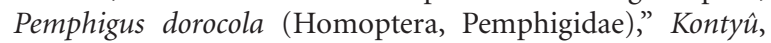
vol. 48, no. 1, pp. 71-73, 1980.

[177] T. G. Benton and W. A. Foster, "Altruistic housekeeping in a social aphid," Proceedings of the Royal Society of London, Series B, vol. 247, no. 1320, pp. 199-202, 1992.

[178] S. Aoki and U. Kurosu, "Soldiers of a European gall aphid, Pemphigus spyrothecae (Homoptera: Aphidoidea): why do they molt?" Journal of Ethology, vol. 4, no. 2, pp. 97-104, 1986.

[179] H. Shibao, M. Kutsukake, J. M. Lee, and T. Fukatsu, "Maintenance of soldier-producing aphids on an artificial diet," Journal of Insect Physiology, vol. 48, no. 4, pp. 495-505, 2002.

[180] H. Shibao, M. Kutsukake, and T. Fukatsu, "Density triggers soldier production in a social aphid," Proceedings of the Royal Society of London, Series B, vol. 271, pp. S71-S74, 2003.

[181] H. Shibao, J. M. Lee, M. Kutsukake, and T. Fukatsu, "Aphid soldier differentiation: density acts on both embryos and newborn nymphs," Naturwissenschaften, vol. 90, no. 11, pp. 501-504, 2003.

[182] H. Shibao, M. Kutsukake, and T. Fukatsu, "The proximate cue of density-dependent soldier production in a social aphid," Journal of Insect Physiology, vol. 50, no. 2-3, pp. 143147, 2004.

[183] H. Shibao, M. Kutsukake, and T. Fukatsu, "Densitydependent induction and suppression of soldier differentiation in an aphid social system," Journal of Insect Physiology, vol. 50, no. 11, pp. 995-1000, 2004.

[184] H. Shibao, M. Kutsukake, S. Matsuyama, T. Fukatsu, and M. Shimada, "Mechanisms regulating caste differentiation in an aphid social system," Communicative and Integrative Biology, vol. 3, no. 1, pp. 1-5, 2010.

[185] S. Aoki, S. Akimoto, and S. Yamane, "Observations on Pseudoregma alexanderi (Homoptera, Pemphigidae), an aphid species producing pseudoscorpion-like soldiers on bamboos," Kontyû, vol. 49, no. 2, pp. 355-366, 1981.

[186] H. Shibao, "Lack of kin discrimination in the eusocial aphid Pseudoregma bambucicola (Homoptera: Aphididae)," Journal of Ethology, vol. 17, no. 1, pp. 17-24, 1999.

[187] S. Aoki and U. Kurosu, "An aphid species doing a headstand: butting behavior of Astegopteryx bambucifoliae (Homoptera: Aphidoidea)," Journal of Ethology, vol. 3, no. 2, pp. 83-87, 1985.

[188] W. A. Foster, "Duelling aphids: intraspecific fighting in Astegopteryx minuta (Homoptera: Hormaphididae)," Animal Behaviour, vol. 51, no. 3, pp. 645-655, 1996. 
[189] G. Morris and W. A. Foster, "Duelling aphids: electrical penetration graphs reveal the value of fighting for a feeding site," Journal of Experimental Biology, vol. 211, no. 9, pp. 1490-1494, 2008.

[190] F. W. Howard, S. Halbert, and R. Giblin-Davis, "Intraspecific dueling in palm aphids, Cerataphis brasiliensis (Homoptera: Hormaphididae)," The Florida Entomologist, vol. 81, no. 4, pp. 552-554, 1998.

[191] D. L. Stern, A. Moon, and C. Martinez del Rio, "Caste allometries in the soldier-producing aphid Pseudoregma alexanderi (Hormaphididae: Aphidoidea)," Insectes Sociaux, vol. 43, no. 2, pp. 137-147, 1996.

[192] N. Ijichi, H. Shibao, T. Miura, T. Matsumoto, and T. Fukatsu, "Soldier differentiation during embryogenesis of a social aphid, Pseudoregma bambucicola," Entomological Science, vol. 7, no. 2, pp. 143-155, 2004.

[193] N. Arakaki, "Shortened longevity of soldiers of the bamboo aphid Pseudoregma koshunensis (Takahashi) (Homoptera: Aphididae) due to attack behaviour," Journal of Ethology, vol. 10, no. 2, pp. 149-151, 1992.

[194] M. Schütze and U. Maschwitz, "Enemy recognition and defence within trophobiotic associations with ants by the soldier caste of Pseudoregma sundanica (Homoptera : Aphidoidea)," Entomologia Generalis, vol. 16, no. 1, pp. 1-12, 1991.

[195] M. W. Moffett, "Samurai aphids, survival under siege," National Geographic, vol. 176, no. 3, pp. 406-422, 1989.

[196] K. Uematsu, M. Kutsukake, T. Fukatsu, M. Shimada, and H. Shibao, "Altruistic defenders in a Japanese gall-forming aphid, Quadrartus yoshinomiyai (Homoptera: Aphididae: Hormaphidinae)," Sociobiology, vol. 50, no. 3, pp. 711-724, 2007.

[197] K. Uematsu, M. Kutsukake, T. Fukatsu, M. Shimada, and H. Shibao, "Altruistic colony defense by menopausal female insects," Current Biology, vol. 20, no. 13, pp. 1182-1186, 2010.

[198] N. Arakaki, "Feeding by soldiers of the bamboo aphid Pseudoregma koshunensis (Homoptera: Aphididae)," Journal of Ethology, vol. 10, no. 2, pp. 147-148, 1992.

[199] N. Arakaki and M. Hattori, "Differences in the quality and quantity of honeydew from first instar soldier and ordinary morph nymphs of the bamboo aphid, Pseudoregma koshunensis (Takahashi) (Homoptera: Aphididae)," Applied Entomology and Zoology, vol. 33, no. 3, pp. 357-361, 1998.

[200] A. W. Shingleton and W. A. Foster, "Behaviour, morphology and the division of labour in two soldier-producing aphids," Animal Behaviour, vol. 62, no. 4, pp. 671-679, 2001.

[201] S. Aoki and U. Kurosu, "Logistic model for soldier production in aphids," Insectes Sociaux, vol. 50, no. 3, pp. 256-261, 2003.

[202] S. Aoki and M. Imai, "Factors affecting the proportion of sterile soldiers in growing aphid colonies," Population Ecology, vol. 47, no. 2, pp. 127-136, 2005.

[203] S. Aoki and U. Kurosu, "How many soldiers are optimal for an aphid colony?" Journal of Theoretical Biology, vol. 230, no. 3, pp. 313-317, 2004.

[204] R. Takahashi, "Aphididae of Formosa, part I," Special Report of Agricultural Experimental Station, Government of Formosa, no. 143, pp. 1-97, 1921.

[205] A. W. Shingleton and W. A. Foster, "Ant tending influences soldier production in a social aphid," Proceedings of the Royal Society of London, Series B, vol. 267, no. 145, pp. 1863-1868, 2000.

[206] D. L. Stern, J. A. Whitfield, and W. A. Foster, "Behavior and morphology of monomorphic soldiers from the aphid genus
Pseudoregma (Cerataphidini, Hormaphididae): implications for the evolution of morphological castes in social aphids," Insectes Sociaux, vol. 44, no. 4, pp. 379-392, 1997.

[207] M. Schütze and U. Maschwitz, "Investigations on the trophobiosis of Pseudoregma sundanica (Homoptera: Aphidoidea: Hormaphididae), a Southeast-Asian aphid with sterile soldiers," Zoologische Beiträge, vol. 34, no. 3, pp. 337-347, 1992.

[208] J. Huang and A. Polaszek, "A revision of the Chinese species of Encarsia Foerster (Hymenoptera: Aphelinidae): parasitoids of whiteflies, scale insects and aphids (Homoptera: Aleyrodidae, Diaspididae, Aphidoidea)," Journal of Natural History, vol. 32, no. 12, pp. 1825-1966, 1998.

[209] G. E. Evans, A. Polaszek, and F. D. Bennett, "The taxonomy of the Encarsia flavoscutellum species-group (Hymenoptera: Aphelinidae) parasitoids of Hormaphididae (Homoptera: Aphidoidea)," Oriental Insects, vol. 29, pp. 33-45, 1995.

[210] R. L. Blackman, Aphids, Ginn and Co., Ltd., London, UK, 1974.

[211] M. Morimoto and H. Shibao, "Predators of the bamboo aphid Pseudoregma bambucicola (Homoptera: Pemphigidae) in Kagoshima, southern Japan," Applied Entomology and Zoology, vol. 28, no. 2, pp. 246-248, 1993.

[212] H. Sasaji, Natural History of the Ladybirds, University of Tokyo Press, Tokyo, Japan, 1998.

[213] Y. Yoshiyasu and K. Ôhara, "A new aphidophagous species of a phycitine genus Cryptoblabes from Japan (Lepidoptera, Pyralidae)," Tyô to Ga, vol. 33, no. 1-2, pp. 51-60, 1982.

[214] S. Moriuti, "Stathmopodidae," in Moths of Japan, Volume 1, H. Inoue, S. Sugi, H. Kuroko, S. Moriuti, A. Kawabe, and M. Owada, Eds., pp. 256-258, Kodan-sha, Tokyo, Japan, 1982.

[215] H. Banno, "Plasticity of size and relative fecundity in the aphidophagous lycaenid butterfly, Taraka hamada," Ecological Entomology, vol. 15, no. 1, pp. 111-113, 1990.

[216] H. Banno, "Dry matter budget and food utilization efficiency of the larvae of aphidophagous butterfly, Taraka hamada (Lepidoptera, Lycaenidae)," Tyô to Ga, vol. 41, no. 4, pp. 243249, 1990.

[217] N. E. Pierce, "Predatory and parasitic Lepidoptera: carnivores living on plants," Journal of the Lepidopterists' Society, vol. 49, no. 4, pp. 412-453, 1995.

[218] S. Aoki and U. Kurosu, "Is aphid attack really effective against predators? A case study of Ceratovacuna lanigera," in Population Structure, Genetics and Taxonomy of Aphids and Thysanoptera, J. Holman, J. Pelikán, A. F. G. Dixon, and L. Weismann, Eds., pp. 224-232, SPB Academic Publishing, The Hague, The Netherlands, 1987.

[219] N. S. Putra and H. Yasuda, "Effects of prey species and its density on larval performance of two species of hoverfly larvae, Episyrphus balteatus de Geer and Eupeodes corollae Fabricius (Diptera: Syrphidae)," Applied Entomology and Zoology, vol. 41, no. 3, pp. 389-397, 2006.

[220] T. Sato and H. Takada, "Biological studies on three Micromus species in Japan (Neuroptera: Hemerobiidae) to evaluate their potential as biological control agents against aphids: 1 . Thermal effects on development and reproduction," Applied Entomology and Zoology, vol. 39, no. 3, pp. 417-425, 2004.

[221] S. Aoki, U. Kurosu, and S. Usuba, "First instar larvae of the sugar-cane wooly aphid, Ceratovacuna lanigera (Homoptera, Pemphigidae), attack its predators," Kontyû, vol. 52, no. 3, pp. 458-460, 1984

[222] N. Arakaki, "Alarm pheromone eliciting attack and escape responses in the sugar cane woolly aphid, Ceratovacuna lanigera (Homoptera, Pemphigidae)," Journal of Ethology, vol. 7, no. 2, pp. 83-90, 1989. 
[223] S. Takano, "On the morphology and biology of Ceratovacuna lanigera Zehntner, and the relation of its outbreak to environmental conditions in Formosa," Journal of Formosan Sugar Plant Association, vol. 11, no. 11, pp. 481-528, 1934 (Japanese).

[224] S. Takano, "The sugar cane woolly aphis, Ceratovacuna lanigera Zehntner, in Formosa," Report of the Government Sugar Experimental Station, Tainan, Formosa, no. 9, pp. 1-76, 1941.

[225] S. Azuma and Y. Oshiro, "Studies on the insect pests of sugar cane in the Ryukyu Islands: (6) On the sugarcane wooly aphis, Ceratovacuna lanigera Zehntner," Bulletin of the Okinawa Agricultural Experiment Station, no. 6, pp. 9-27, 1971 (Japanese).

[226] B. K. Agarwala, S. Saha, and A. K. Ghosh, "Studies on Ceratovacuna silvestrii (Takahashi) (Homoptera: Aphididae) and its predator Anisolemnia dilatata (Fab.) on Bambusa arundinacea," Records of the Zoological Survey of India, vol. 81, no. 3-4, pp. 23-42, 1984

[227] A. E. de C. Campos-Farinha and F. J. Zorzenon, "Predatory and interaction behaviors of Paratrechina fulva (Mayr) (Hymenoptera: Formicidae) on phytophagous insects on palm trees," Revista Arquivos do Instituto Biológico, vol. 72, no. 1, pp. 143-144, 2005.

[228] R. L. Blackman and V. F. Eastop, Aphids on the World's Crops: an Identification and Information Guide, Wiley, Chichester, UK, 1st edition, 1984.

[229] U. Maschwitz, W. A. Nässig, K. Dumpert, and K. Fiedler, "Larval carnivory and myrmecoxeny, and imaginal myrmecophily in miletine lycaenids (Lepidoptera, Lycaenidae) on the Malay Peninsula," Tyô to Ga, vol. 39, no. 3, pp. 167-181, 1988.

[230] K. Fiedler and U. Maschwitz, "Adult myrmecophily in butterflies: the role of the ant Anoplolepis longipes in the feeding and oviposition behaviour of Allotinus unicolor," Tyô to $G a$, vol. 40, no. 4, pp. 241-251, 1989.

[231] D. J. Lohman and V. U. Samarita, "The biology of carnivorous butterfly larvae (Lepidoptera: Lycaenidae: Miletinae: Miletini) and their ant-tended hemipteran prey in Thailand and the Philippines," Journal of Natural History, vol. 43, no. 9-10, pp. 569-581, 2009.

[232] E. M. Patch, "Woolly aphids of the elm," Bulletin of Maine Agricultural Experimental Station, no. 220, pp. 259-273, 1913.

[233] T. Komatsu and S. Akimoto, "Genetic differentiation as a result of adaptation to the phenologies of individual host trees in the galling aphid Kaltenbachiella japonica," Ecological Entomology, vol. 20, no. 1, pp. 33-42, 1995.

[234] W. A. Foster and T. G. Benton, "Sex ratio, local mate competition and mating behaviour in the aphid Pemphigus spyrothecae," Behavioral Ecology and Sociobiology, vol. 30, no. 5, pp. 297-307, 1992.

[235] U. Kurosu and S. Aoki, "Galls of the aphid Nipponaphis distyliicola remain closed for more than one year," in Aphids in Natural and Managed Ecosystems, J. M. Nieto Nafría and A. F. G. Dixon, Eds., pp. 235-241, Universidad de León (Secretariado de Publicaciones), 1998.

[236] M. Miyazaki, "Forms and morphs of aphids," in Aphids, Their Biology, Natural Enemies and Control, Volume 2, A. K. Minks and P. Harrewijn, Eds., pp. 27-50, Elsevier, Amsterdam, The Netherlands, 1987.

[237] U. Kurosu and S. Aoki, "Why are aphid galls so rare," Evolutionary Theory, vol. 10, pp. 85-99, 1991.
[238] Y. Yamaguchi, "Sex ratios of an aphid subject to local mate competition with variable maternal condition," Nature, vol. 318, no. 6045, pp. 460-462, 1985.

[239] M. T. Ghiselin, The Economy of Nature and the Evolution of Sex, University of California Press, Berkley, Calif, USA, 1974.

[240] G. Bell, The Masterpiece of Nature: The Evolution and Genetics of Sexuality, Croom Helm, London, UK, 1982.

[241] W. D. Hamilton, Narrow Roads of Gene Land, Volume 2: Evolution of Sex, Oxford University Press, Oxford, UK, 2002.

[242] J. S. Kennedy and H. L. G. Stroyan, "Biology of aphids," Annual Review of Entomology, vol. 4, pp. 139-160, 1959.

[243] Y. Tosaka and T. Nishida, "Gall surface area is a simple and accurate measure of fitness in Nipponaphidini galling aphids (Homoptera: Aphididae)," Applied Entomology and Zoology, vol. 42, no. 2, pp. 217-221, 2007.

[244] S. Aoki, "Colophina clematis (Homoptera, Pemphigidae), an

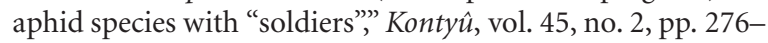
282, 1977.

[245] S. Akimoto, "Soldier-like nymphs in the pemphigid aphid Colophina clematicola (Pemphigidae: Aphidoidea)," Entomological Science, vol. 1, no. 1, pp. 33-36, 1998.

[246] N. Ijichi, H. Shibao, T. Miura, T. Matsumoto, and T. Fukatsu, "Analysis of natural colonies of a social aphid Colophina arma: population dynamics, reproductive schedule, and survey for ecological correlates with soldier production," Applied Entomology and Zoology, vol. 40, no. 2, pp. 239-245, 2005. 

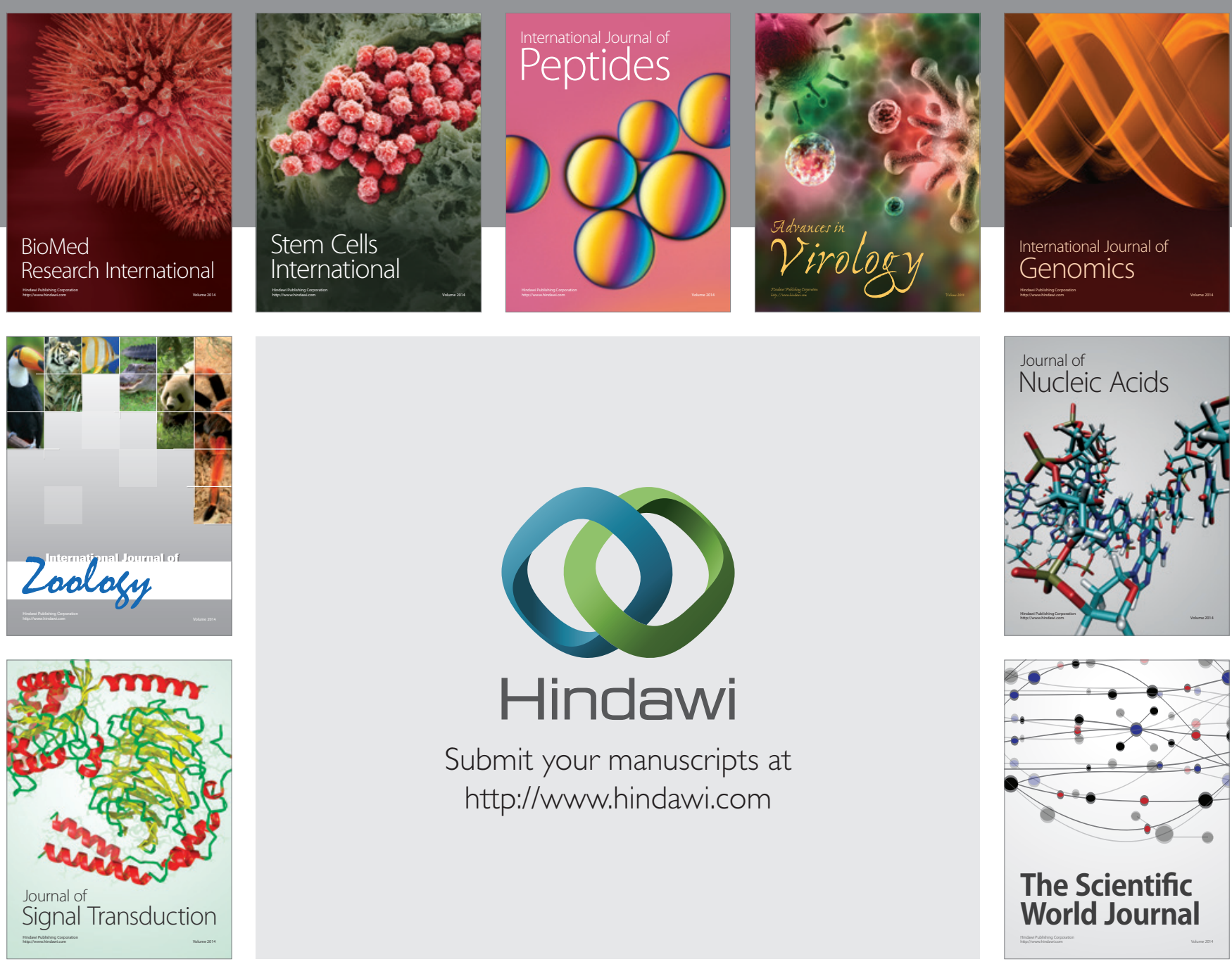

Submit your manuscripts at

http://www.hindawi.com
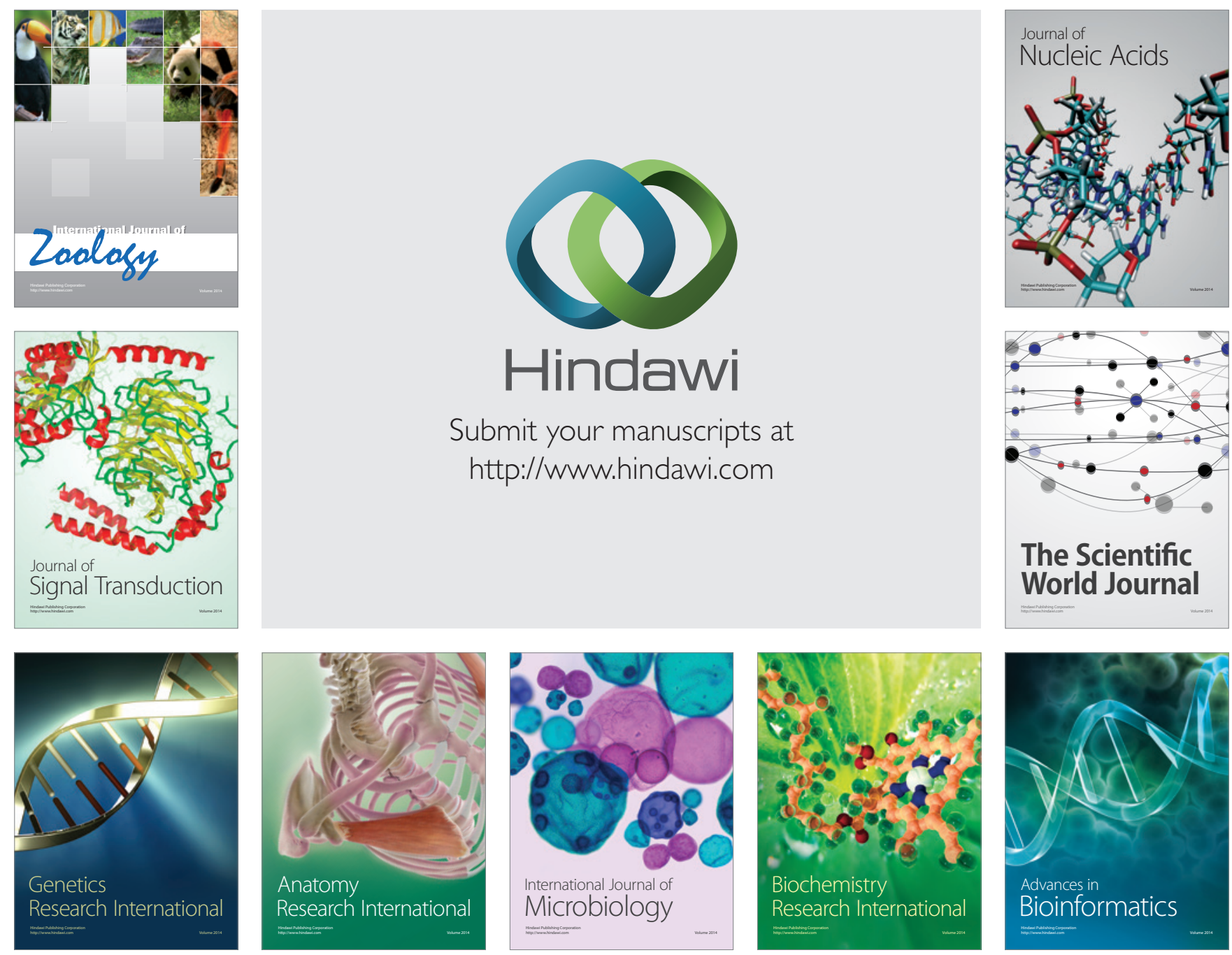

The Scientific World Journal
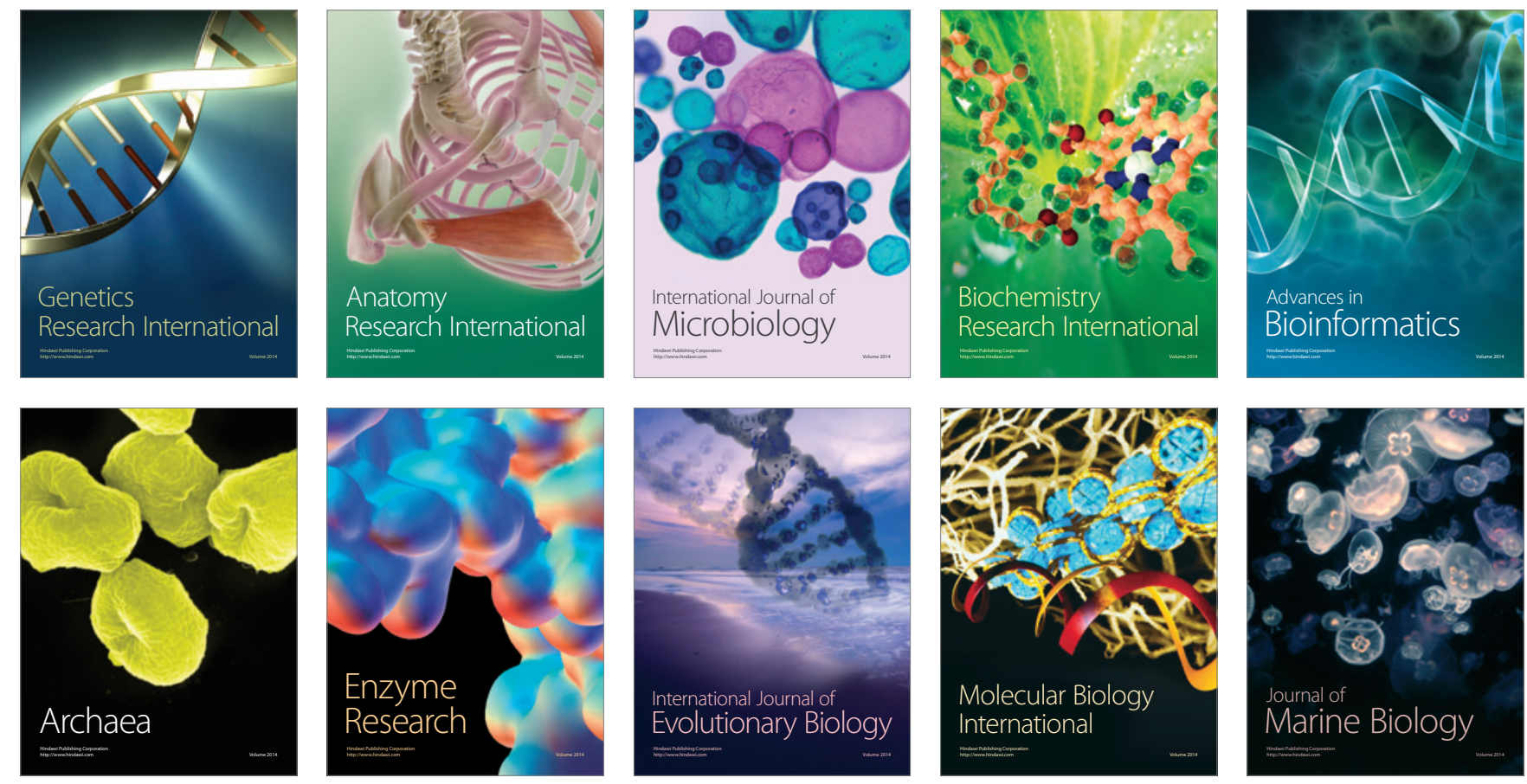